. 



\section{CHATS ON OLD SHEFFIELD \\ PLATE}




\section{CHATS ON OLD SILVER}

\section{CONTENTS}

\section{CHAPTER}

I. The MARKS STAMPED UPON SILVER

II. Ecclesiastical Plate

III. The Mazer, the Standing Cup, the Flagon, the TANKARD, THE BeAKer, THE WINE CuP

IV. The Salt Cellar

V. THE SpooN

VI. The Posset Pot, the Porringer

VII. The Candlestick

VIII. The Teapot, the Coffee Pot, the Tea Caddy

IX. The Caster, the Sugar Bowl, the Cream Pail, the Cake Basket

X. The Cream Jug

XI. SCOTTISH Silver

XII. IRISH SILVER

APPENDIX. - TABLES OF DATE LeTters, LoNDON (I598I905)-TABLE OF Differences IN SHIELdS, LONDON (Elizabeth TO GEORge V)-Illustrations OF Marks, London, Provincial, Scottish and Irish 



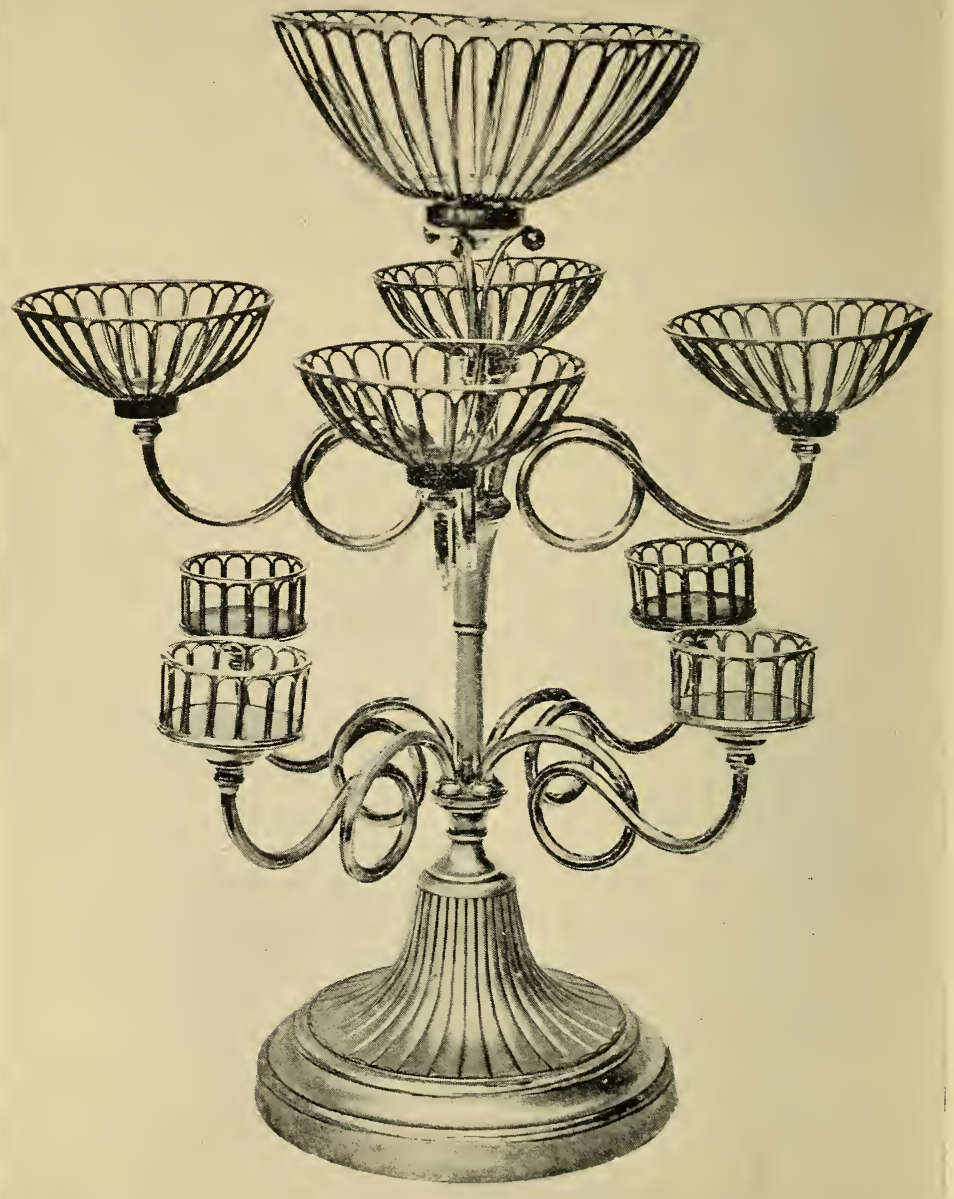

OLD SHEFFIELD PLATED CENTKEPIECE.

On circular base, with nine plated wire baskets for glass dishes on spiral branches. Date $1775^{-1780}$.

(In the collection of B. B. Harrison, Esq.) 


\title{
$x$ \\ ChATS ON \\ Old Sheffield Plate
}

\author{
BY \\ ARTHUR HAYDEN \\ AUTHOR OF "CHATS ON OLD SILVER," "CHATS \\ ON OLD CLOCKS" ETC.
}

WITH FRONTISPIECE AND 58 FULL-PAGE ILLUSTRATIONS

INCLUDING 5 PAGES OF MAKERS' MARKS

T. FISHER UNWIN LTD

LONDON: ADELPHI TERRACE

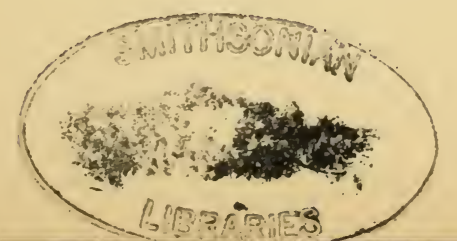


First published . . 1920

Second Impression . . 1924

(All rights reserved) 
TO MY FRIEND

\section{WALTER IDRIS,} IN APPRECIATION OF KINDRED RECOGNITION 



\section{PREFACE}

MANY readers have importuned me to write a companion volume to my Chats on Old Silver, to complete the chain of evolution of the metalsmith's art in regard to silver plate and silver plated ware. Accordingly this volume appears as a complementary and companion volume to that on "Old Silver," and although the former describes the history and character of the silversmiths' work from Elizabeth to Victoria, the present volume covers a much shorter period, approximately a hundred years, when the plater's skill, in what is now generally known as old Sheffield Plate, of superimposing a thin sheet of silver on a copper base, won a triumph in the great art of simulation until it was superseded by the modern electro-plating process.

The invention was discovered and first practised at Sheffield, but it soon covered a wider area, and plated ware by fusion and rolled was made at Birmingham, London, Nottingham and elsewhere. But it still retains the name of Sheffield Plate, and nothing can remove this title from the public mind, although it is a misnomer. "Sheffield 
Plate" is Sheffield solid silver duly assayed at the Sheffield Assay Office, which has existed since I773, and bears the crown as the town mark together with the maker's initials and the date letter, the same as sterling silver plate assayed at London, Birmingham, Chester, Edinburgh, Dublin, or any other of the assay offices. Sheffield Plated Ware is a copy or simulation of real plate. It was, as this volume shows, possessed of considerable artistic qualities, it was fashioned by craftsmen who were masters of a clever technique, and it is, if not a lost art, certainly an art not practised in the old methods nor with the same exactitude nowadays, and as such it is worthy of the serious attention of the collector.

As to its artistry purists may cavil at its imitativeness. Although "imitation is the sincerest form of flattery" the contemporary silversmiths of London and elsewhere were far from flattered. They began to be alarmed at the growth of the manufacture, and protective Acts of Parlianent were passed to safeguard the interests of silversmiths against competition by silver platers.

In regard to technique I have given sufficient details to enable collectors to identify their possessions and to take a further interest in details of craftsmanship.

By permission of the Board of Education I am reproducing several designs from the copperplate illustrations of the old Catalogues and 
Pattern Books issued to buyers of their wares on the Continent of Europe by the leading firms of Sheffield in the eighteenth century.

In regard to information concerning the manufacture of plate by fusion at Dublin I am under an obligation to Dudley Westropp, Esq., of the National Museum, Dublin, for notes embodied herein relating to the importation of Sheffield plated ware into Ireland and its attempted manufacture there.

I have also to acknowledge the kindness of G. Harry Wallis, Esq., F.S.A., of the Nottingham Museum and Art Gallery, for the inclusion of illustrations of several examples.

The Corporation of Sheffield have allowed me to have special photographs taken of examples exhibited in the Public Museum, Sheffield, and I am indebted to the Curator, E. Howarth, Esq., for his courtesy in enabling this to be carried out successfully.

I have had access by the kindness of collectors to several representative collections. I am especially indebted to B. B. Harrison, Esq., for enabling me to illustrate herein many fine examples from his choice collection.

To Walter H. Willson, Esq., I have to express acknowledgment for allowing me to reproduce illustrations of specimens of old Sheffield plated ware that have passed through his hands for many years, and for much information afforded me in connection with the old technique. 
In regard to marks on old Sheffield and other plated ware, in view of strictures on marks laid down by Acts of Parliament, I have come to the conclusion that marks on old Sheffield plated ware are somewhat negligible, as they lack the authoritative exactitude of those placed by law on silver plate. There were marks when the Sheffield makers simulated silver marks till they alarmed the silversmiths and were stopped by statute. Then came a hiatus. Then again they adopted trade marks plentifully found, but these marks are not always found on examples of the best period. So in adjudging old Sheffield plated ware, marks have a subsidiary place, and they are accorded a subsidiary place in this volume.

I submit this volume unhesitatingly to lovers of old Sheffield plated ware as a carefully considered exposition of what was produced for a hundred years, consisting of fine design, exquisite balance, and wonderful technique, till plating became a scientific process and electro-plating became of common usage. But this is modernity.

ARTHUR HAYDEN. 


\section{CONTENTS}

\begin{tabular}{|c|c|c|c|c|c|}
\hline & & & & & PAGE \\
\hline PREFACE & - & . & - & . & - 7 \\
\hline LIST OF & ILLUSTRATIONS & - & - & . & - $\quad$ I3 \\
\hline
\end{tabular}

\section{CHAPTER I}

INTRODUCTION

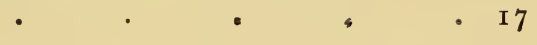

CHAPTER II

EARLY DAYS (THE INVENTION OF SILVER-PLATING BY FUSION AT SHEFFIELD) • • • • 43

CHAPTER III

CANDELABRA AND CANDLESTICKS

CHAPTER IV

SALT CELLARS AND MUSTARD POTS

CHAPTER V

CAKE BASKETS, DECANTER STANDS (COASTERS), DISH OR POTATO RINGS, INKSTANDS AND TAPER

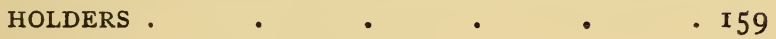

\section{CHAPTER VI}

TEAPOTS, TEA AND COFFEE SETS, TEA KETTLES, COFFEE POTS, SUGAR BASINS 
CHAPTER VII

SOUP TUREENS, HOT WATER JUGS, THE SUPPER TABLE. 2 I 7

\section{CHAPTER VIII}

CENTREPIECES .

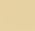

。

- 243

CHAPTER IX

Close PLATING

. 259

APPENDIX, MARKS ON OLD SILVER (1753-1840) . 271

99

MARKS ON OLD SHEFFIELD PLATE

. 285

INDEX .

. 295 


\section{ILLUSTRATIONS}

Old Sheffield Plated Centre-piece .

Frontispiece

Chapter I.-Introduction

Soup Tureen and Fruit Dish carved in Pear-wood. . 29

Wedgwood Dessert Basket and Dessert Centrepiece • 33

Group of Silver Lustre Ware and Glass Candlesticks • 37

\section{Chapter II.-EARLy DAYS}

Knives, with Medallion of Shakespeare . . . 5I

Wine Label, Buttons $\quad . \quad$. $\quad$. $\quad$. 5 I

Group of Patch Boxes . . . . . 55

Candlestick, 1775, from Old Pattern Book (18th century) . 65

Candlestick, 1795, Old Pattern Book (18th century) . 69

Candlesticks, 1797, Old Pattern Book (18th century) • 75

\section{Chapter III.-CANDELABRA AND CANDLESTICKS}

Candlestick, 1785 . $\quad . \quad$. $\quad . \quad . \quad .83$

Candelabrum, 1800 . $\quad . \quad$. $\quad . \quad$. $\quad .87$

Candelabrum (7-lights), I820.

Candelabrum (5-lights), 1810. $\quad$. $\quad . \quad .93$

Candelabrum (2-lights), I790. $\quad . \quad$. $\quad .97$

Candelabra, I790 . $\quad . \quad$. . . . . IOI

Candelabrum (Single twist), I790 . . . . . . 103

Candelabrum (Double twist) . . . . . . 107

Candelabrum, I795; Candelabrum, I790-1795 . . III

Candelabrum, Small, Candlestick, Lyre Design . . II3

Candelabrum (3-lights), I805; Candelabrum (4-lights), I8Io II7

Candelabrum (3-lights), I820. 
Candelabra and Candlesticks-continued Table Candlesticks, 1765, 1770, 1795 . . . 127

Table Candlesticks, 1780, 1790, 1795 . . . . 129

Table Candlesticks, 1810, 1820, 1830 . . . . 129

\section{Chapter IV.-Salt Cellars and Mustard Pots}

Salt Cellars, from Old Pattern Book (18th century) . 137

Salt Cellars, from Old Pattern Book (18th century) . I4I

Mustard Pots, from Old Pattern Book (I8th century) . I45

Mustard Pots, I775, 1785, I790 . . . . 149

Mustard Pots, from Old Pattern Book (18th century) . I5I

Pepper Casters, Group of . . . . . 155

Mustard Pots, Group of . $\quad$. $\quad$. $\quad$. $\quad$. 155

Chapter V.-Cake Baskets, Decanter Stands, Dish Rings, INKSTANDS, ETC.

Cake Baskets, Wire Work, I800, 1810 . . . 163

Decanter Stands (Coasters), Group of, 1785-1790 . . 167

Decanter Stands (Coasters), Group of, 1805, 1810, 1815 . 169

Decanter Stands (Coasters), Group of, I805, 1820. . 173

Butter Dish . . . . . . 175

Dish or Potato Ring . . . . . . . 175

Inkstands, from Old Pattern Book (I8th century) . $\quad$ I79

Taper Holders, from Old Pattern Book (18th century). . 183

Chapter VI.-Teapots, Tea Kettles, Coffee Pots, SUGAR BASINS

Teapot, 1792, from Old Pattern Book (I8th century) . I9I

Teapot and Tea Caddies, Cake Basket . . . 193

Tea and Coffee Sets, 1810, 1820 . . . . . . 197

Tea and Coffee Sets, 1825, 1830 . . . . . . 199

Tea Urn, 1810 . . . . . . 203

Tea Kettles and Stands, 1805, 1820 . . . 207

Coffee Pot, French, Silver-plated; Sugar Baskets, Pierced

Work . . . . . . $2 I I$

Sugar Baskets, 1825 • $\quad . \quad$. $\quad . \quad \cdot \quad$. 213 


\section{ILLUSTRATIONS}

Chapter Vil.-Tureens, Hot Water Jugs, Etc.

PAGE

Soup Tureen, 1805 • $\quad . \quad$. $\quad$.

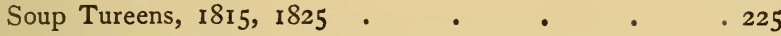

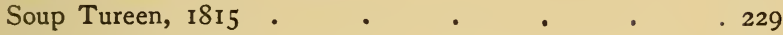

Hot Water Jugs (2) . $\quad$. $\quad$. $\quad$ • . 229

Entrée Dishes, 1815, 1825 . . . . . . . 233

Hot Water Jug, Adam style, I770 . . . . . 235

Toasted Cheese Dishes, 1800, 1810. . . . 239

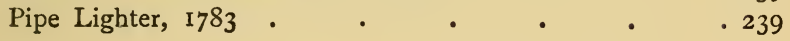

\section{Chapter VIII.-Centrepieces}

Centrepieces, I790, I810 . $\quad$ • . . . 247

Centrepiece, with Female Figures . . . . 25I

Chestnut Dish ; Fruit Basket, I81o . . . . 255

\section{APPENDIX}

Marks on Silver Plate

$275,279,283$

Marks on Old Sheffield Plate

- 287,291 

I

\title{
INTRODUCTION
}

\author{
IMITATION AS A FINE ART \\ ECONOMIC SUBSTITUTION \\ EUROPEAN IMITATIVENESS \\ PARALLELS IN ENGLISH CRAFTSMANSHIP \\ EARLY PLATING \\ SILVER PLATERS AT SHEFFIELD
}





\section{CHAPTER I \\ INTRODUCTION}

Imitation as a fine art-Economic substitution-European imitativeness-Parallels in English craftsmanship-Early plating-Silver platers at Sheffield.

ImITATION is no new thing in art. Indeed it may be advanced as an axiom that no art worthy of the name has ever come into being without inheriting the traditions and technique of some preceding motifs. Bizarre movements have at one time and another seized artists and craftsmen, they have become anarchist in regard to all previous art postulates, and produced somewhat chaotic and formless results. The fantastic jazz in art circles known as L'Art Nouveau some years ago, temporarily upset the balance of the younger generation of designers, spent its force in unchecked licence, and ended so ignominiously that it is now entirely forgotten, nor has it left any permanent impression upon succeeding schools.

Now and again imitation has been resorted to by well-known masters to flagellate the taste of their own day. Embittered by constant praise 


\section{CHATS ON OLD SHEFFIELD PLATE}

of old works they have made imitations of old masters' styles and foisted them on their critics until at such moment they divulged their authorship and pricked the bubble of the undue adoration of the ancients. Pierre Mignard fabricated a Magdalen and through the complicity of a dealer it was sold as a newly discovered Guido to the Chevalier de Clairville. Presently it was noised about that the painting was by Mignard. Le Brun, the great painter, pronounced it to be a Guido and in his best manner. The jest had gone far enough, the owner, Mignard, Le Brun, and the critics met to settle the affair. Le Brun and the critics adhered to their belief in its authenticity. Mignard protested otherwise, and said he had painted the work over the portrait of a cardinal, and as proof dipped a brush in oil and disclosed the cardinal's hat. Le Brun, bursting with anger, satirically exclaimed, "Always paint Guido but never Mignard." But the canvases of Mignard and Le Brun both hang together in the leading galleries of Europe.

Nor is this a solitary instance of the pique of artists for lack of discernment in contemporary criticism. Goltzius, that masterly exponent of strongly graved lines on the copper, produced and published six prints in the style of Albert Dürer, Lucas van Leyden and others, and one, the Circumcision, was sold as one of Dürer's finest achievements. These six engravings of Goltzius are known among his work as the " master- 
pieces." They are certainly masterly imitations, and he executed them to show his critics that though his was a new style, yet he could if he chose slavishly follow the manner of the old masters. These are instances of imitation used ironically as a weapon to pour scorn on the mediocrity and want of knowledge of critics.

In pictures there have been whole generations of imitators and copyists. The continent in the eighteenth century was flooded with sham Correggios, Claudes, Poussins, and Cuyps, and many English painters, afterwards well known, did not disdain to make copies for the dealers of old masters' pictures. David Allan, called the " Scottish Hogarth," was an adept in copying chalk drawings from the old masters ; and many artists eked out a pitiable existence as copyists while waiting for the public to acclaim their original work. John Jackson copied the head of Reynolds for Chantrey which could have passed for the original by Sir Joshua. A Rubens he painted in the presence of the students of the Royal Academy was acclaimed as faithful to the original. $\mathrm{He}$ was unequalled in such facsimile imitations. Henry Liverseege, in the early days of the nineteenth century, copied Vandyck, Rubens, and Teniers with such skill that few could say which was the original and which the copy. Two pictures, one by Sir Edwin Landseer, and the other a copy, were to be sold on successive days at auction. The painter, strolling in to the auction 


\section{CHATS ON OLD SHEFFIELD PLATE}

room on the day before the copy was sold, mistook it for his own work.

At the galleries of the Fine Art Society, in Bond Street in I875, an exhibition was held of a series of facsimiles of Turner drawings in the National Gallery lent by Ruskin and executed for him by Mr. Ward. Of these replicas, Ruskin said in a note: "I have given my best attention during upwards of ten years to train a copyist to perfect fidelity in rendering the works of Turner, and have now succeeded in enabling him to produce facsimiles so close as to look like replicasfacsimiles which I must sign with my own name to prevent their being sold for real Turner vignettes."

Economic Substitution.-But imitation has many phases. Modern photography in copying the great works of old masters has made it possible to study their works with exactitude in the dimensions of black and white, and if the work is an etching or an engraving the reproduction claims a closer relationship with the original. The art of engraving from painters' work is imitative to the extent that it depicts the same subject and takes its initial inspiration from the painted canvas. But it claims a much higher regard-the great school of interpretative engravers translated painting into terms of black and white.

Economically, therefore, it will be seen that there is a real reason why imitative art, on whatever plane it finds itself, should hold its place. 
In a broad sense it has had a mission. It is true, as Goethe said, that "There are many echoes but few voices"; but the echoes have their value too until they reverberate into nothingness and new voices arise. As a substitute, therefore, for unattainable works of art any medium that will so successfully simulate the original as to convey the lines and the grace, the colour and the harmony, though in a lesser degree than the original, is to be welcomed for its own sake.

There are many occasions when sacrifices have had to be made and when prototypes have been destroyed and substitutes have arisen which have artistically filled the hiatus, if only for the time being. For instance, the extravagance of Louis XIV in regard to sumptuous silver passed all bounds. At a fête at Versailles in I668 on each side of the royal buffet was elevated on a portico ten feet high a grand silver guéridon bearing a massive silver girandole which lighted the buffet, accompanied by numerous large silver vases. On the table and steps of the buffet, which reached the height of twenty-five feet, were arranged twenty-four massive bowls of fine workmanship-these were separated by as many large vases, cassolettes and girandoles of great beauty. There were on the table twenty-four large silver jardinières full of flowers, in front was a great silver cistern shaped like a shell, at the two extremities were four guéridons, six feet high, surmounted by silver girandoles. Two other tables 


\section{CHATS ON OLD SHEFFIELD PLATE}

for the ladies were similarly equipped with masterpieces of the silversmiths' art.

In 1688 the Grande Monarque needed money to carry on his wars, and he issued an edict forbidding the manufacture of such massive silver, and sent all his plate to the Mint. So all this fine work, designed, made by Claude Ballin, Pierre Germain, Montars and other celebrated craftsmen after designs by Le Brun, was melted down; happily the pieces were first drawn by the artist goldsmith Delaunay and their forms are preserved. The king made it compulsory that the fine plate of the nobility should be sacrificed too, and in consequence most of the fine old silver was melted down.

But here comes the imitative note. The age of sumptuous silversmiths' work was followed by an age of fine pottery. Beautifully decorated earthenware and porcelain became fashionable. Rouen made a special service for Louis XIV, and a great impetus was given to the art of the factories of Moustiers, Marseilles and Nevers, and thus the nobles of France had their banquets from the clay of the potter instead of from the vessels of the silversmith.

As will be shown later the relationship between the art of the potter and that of the silversmith has always been somewhat closely allied. The designs of the one have, although not necessarily adapted to a differing technique, been boldly taken and assimilated in results that leave their 
note of incongruity to be criticized by collectors and connoisseurs to-day.

European Imitativeness. - In order to arrive at a closer appreciation of the niceties of imitation, perhaps it would be better to commence by attempting to understand what is originality and where it can be found. But that would entail a great amount of study. In porcelain one would have to follow the attempts of the Dutch school of potters and bow down in admiration to Meissen, where the first true porcelain was made in Europe. All else is imitative, including Sèvres and Wedgwood and Worcester. Nor does imitation stand arrested at technique, it follows slavishly the oriental prototype in design. We find pagodas and Chinese landscapes, and little figures which meant so much in a language of symbolism, scattered promiscuously on Delft beakers and on Bow cups. Wedgwood, in his Portland Vase, copied a prototype of blue glass. In his classic subjects in relief on his vases and his cameos he builded on the reputation of Greek and Roman types translated through the brain of John Flaxman, and there was a school of potters who came second-hand after Wedgwood and imitatively carried on his classic style.

The whole of the school of decorating furniture in lac is imitated from the East, and a poor imitation at best.

What the glass-worker did at Venice was copied over the Alps in Germany. It suffered in trans- 


\section{CHATS ON OLD SHEFFIELD PLATE}

lation and finally became something new. The bulbous appendages to German glass were the crescendo note of the Italian more reticent ornament. When the Murano glass-worker added the tiny griffin-like symbolized version of the small sea-horse found in the Adriatic to the handles of his tazzas, he added a touch of grace and beauty. But the German developed these into chimerical beasts.

In an examination of European art one wonders where imitation ends and where originality begins. Originality unfortunately often begins just at that point when the original touch of genius is lost sight of and when banal excrescences are added, meaningless and offensive.

But originality and fertility of design often begin when experimentalists set out to produce one thing and realized another, and commenced a new technique and became original in so doing. The search for the philosopher's stone was futile, the old alchymists in their laboratories, though they never found the means of transmuting baser metals into gold, made experiments which begat the results of modern science.

Impulses are carried out in various countries in accordance with national limitations. The East African negro who patiently covers a gin bottle with bead-work, proudly displayed as native art by a missionary society in London, is obeying the instinct to embellish and add his own genius to that of the alien. He knows the 
value the white man puts on the spirit bottle, and he worships afar off at the same shrine.

Parallels in English Cratfsmanship. - In regard to Sheffield plated ware, if it be advanced that it was imitative of old silver and therefore negligible, we must claim as a parallel old English earthenware, where, although the technique differed from that of the potting of porcelain, it did simulate porcelain, and examples of the one are found in replica of the other. As to production the reason for imitativeness is often to effect economy. Nor should this be anathema in art. Undoubtedly Staffordshire and all its products struck hard at the English porcelain factories. But, in spite of its initial imitativeness and its wary regard for competitive lines, it did win a path of its own. There the parallel ceases because earthenware was made in England prior to porcelain.

Imitativeness in various arts is common enough. The glass-worker and the potter copied the silversmith. The cabinet-maker was indebted to both and vice versa. We find acanthus ornament in wood and in metal, the strapwork of the Tudor carver on wood and on silver. The cupid in metal on the Stuart clock case is duplicated in the stretcher of the chair carved in walnut, and is found in stone at Hampton Court and St. Paul's in similar ornament. Wedgwood snatched the topographical designs from copperplate engravings to decorate his service for Catherine II of Russia, depicting English country 


\section{CHATS ON OLD SHEFFIELD PLATE}

seats and views. Chippendale borrowed from the Chinese, and echoed Marot, the French designer, in his original designs which burst upon the town in his Director.

Nor does it seem to trouble the collector of china overmuch that Worcester copied oriental models and even used a spurious Chinese mark, that Bow boldly proclaimed itself as "New Canton," and copied Worcester, and that Lowestoft copied both. The invention of transfer printing upon china is claimed by Worcester, by Liverpool and by Battersea, and all three employed designs which were not original. The whole school of designs transfer-printed upon china is imitative, many of them had already appeared as illustrations to books.

Take another art, that of stipple engraving printed in colours. Here indeed is an imitative art. An engraving in black and white is a translation of a subject in colours. When printed in colours it sets out to be imitative of another art. But collectors have not been shy to give as much as four figures for some of these eighteenth century colour prints, greater prices even than the original paintings would bring under the hammer. The subject is illimitable and provocative of much argument.

As interesting examples showing the versatility of designers, and that potters and silversmiths and woodworkers not only touched at many points but actually assimilated designs more 


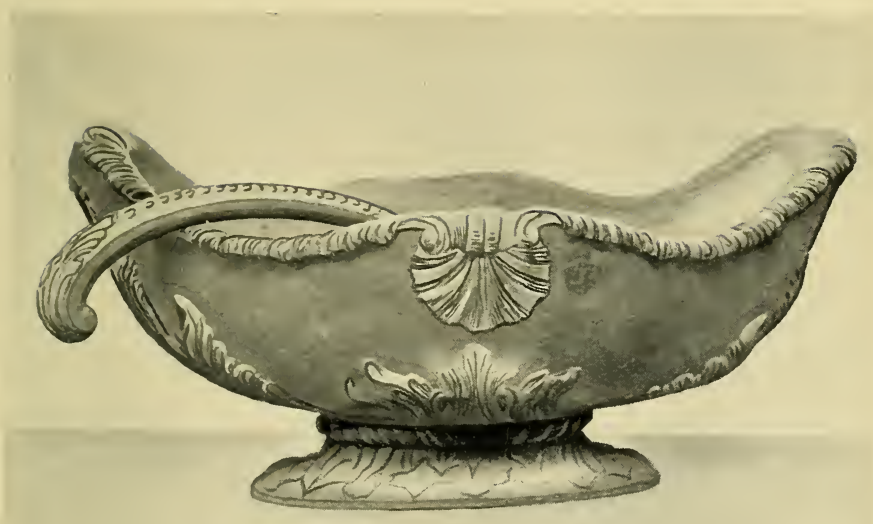

SOUP TUREEN AND LADLE CARVED IN PEAR-WOOD.

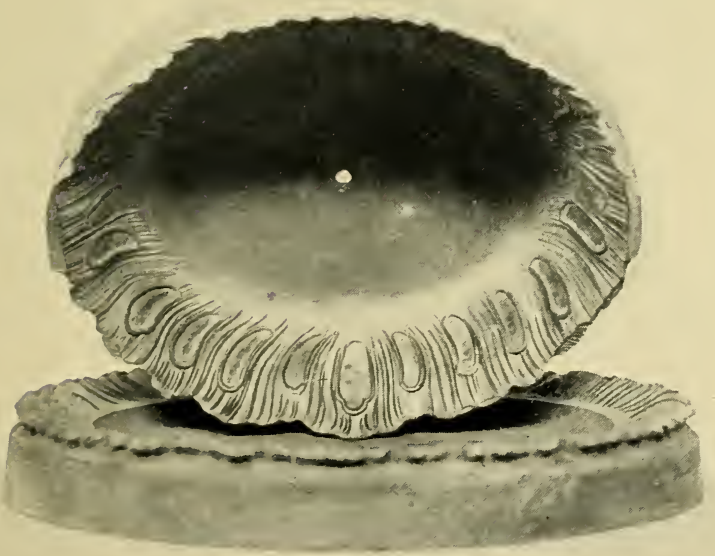

FRUIT DISH AND STAND CARVED IN PEAR-WOOD.

(At the Wedgrwood Museum at Etruria.) 

proper to another technique in which they were working. The technique of the metal workers should have little to recommend its adoption by the cabinet-maker, yet we find tea caddies in Chippendale's Director which have details certainly more fit to be executed as mounts by the French ormulu workers than by the English wood-carvers, even though in soft mahogany. Josiah Wedgwood availed himself of many suggestions from other fields than that of pottery. A Soup Tureen and Ladle carved in pear-wood is at the Museum at Etruria to prove this excursion of his for models. This illustration (p. 29) clearly shows a design, although executed in wood, having certain ornaments which more properly belong to the technique of the silversmith.

Another carved pear-wood model is that of a Fruit Dish and Stand. Here again there peeps forth not so much the technique of the woodcarver as the peculiar and more easily obtainable ornament of the metal worker. It might be a Sheffield plated Decanter Stand or Coaster.

Josiah Wedgwood's collection of shells provided him with many a model for his cream ware dishes. $\mathrm{He}$ has used the small flattish escallop like shells-Pholus AEstatus, Pectem Japonicum, Area Antiquat and others, with great effect and crudely suggested the natural colours. In these the silversmiths helped themselves liberally to Wedgwood's models and we find innumerable single shell designs prevalent since their adoption 


\section{CHATS ON OLD SHEFFIELD PLATE}

in pottery by Wedgwood. It would similarly appear that they were equally indebted to him for another of his bold replicas of nature in the fine Dessert Centrepiece (illustrated, p. 33). As spoon-warmers and for other purposes the silversmith found this model from old Josiah's conchological collection remarkably practical and accordingly lost no time in imitating it.

Another Wedgwood piece, a Dessert Basket illustrated, p. 33) proves that Josiah had his own back, for the pierced ornament is distinctly taken from the silversmith and is more proper to his art than to that of the worker in clay. ${ }^{x}$ "One can trace the motives of much of his work, both as to form and decoration, in the collections of various kinds which he was amassing, and in his constant intercourse with the metal-workers of Sheffield and Birmingham. To the former source he was indebted for the designs derived from objects of natural history, particularly shells and plants; to the latter source he owed many shapes and methods of decorative treatment which were used for silver plated ware." His introduction of diapers and other conventional designs in pierced and perforated work come straight from the Sheffield silver platers, and this style of ornamentation done in the same county as Sheffield, at the Leeds pottery, was carried to its extreme limit by Messrs. Hartley Green \& Co., who became the most successful imitators

1 Josiah Wedgwood, by Professor Church, igo3. 


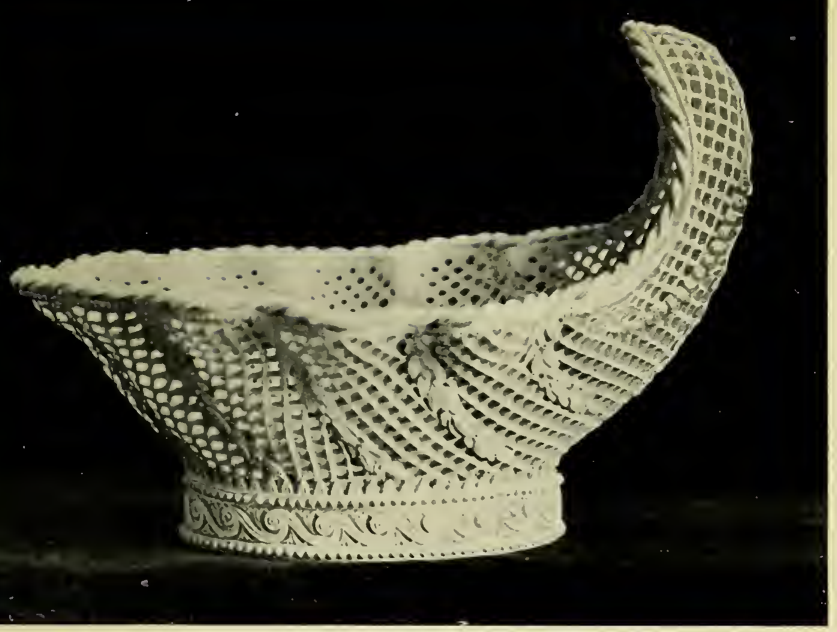

WEDGWOOD CREAM WARE DESSERT BASKET.

Showing fine pierced work.

(Reproduced by the courtesy of Messrs. Fosiah Wedyowood \& Sons.)

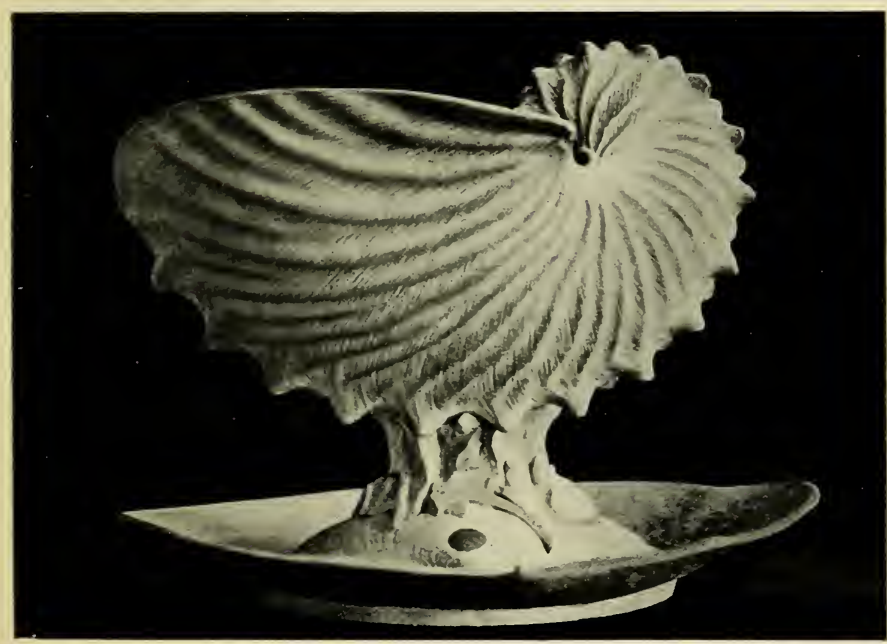

WEIGWOOD CREAM WARE DESSERT CENTREPIECE.

Designed from Josiah Wedgwood's collection of shells. (In the Museum at Etruria.)

(Reprodı ced by the courtesy of Messrs. Fosiah Wedgrwood Eo Sons. 

of Wedgwood's cream ware, about the year I783.

The illustration (p. 37) shows the competitive repetition of design contemporary with Sheffield plate. The potter found earthenware, covered with a fine platinum glaze, was a colourable imitation of silver plate. If the squire had his plate and persons of lesser degree more economically inclined had their Sheffield plate, the cottager could have a fine, glittering array of silver lustre vessels. Nor was the glass-worker behindhand in coming into the field, as the illustration shows.

Early Plating.-In early days silver was used sparingly before the Spanish fleets from South America had poured silver into Europe. Ancient drinking vessels of wood such as the mazer, a drinking bowl much like a punch bowl, were decorated with silver bands. Cocoa-nut cups were similarly decorated. By the end of the sixteenth century, solid silver had replaced most of these forms for use in the spacious days of Elizabeth. The early records show that certain goldsmiths were guilty of mals outrages. In the fourteenth century gold was debased by mixing it with glass, silver by adding lead or fine sand. Latten and brass vessels were silvered and passed off as being of solid silver. One Edward Bor in 1376 was summoned before the mayor and aldermen of London to make answer "that he had silvered 240 buttons of latone and 34 circlets of latone for purses called gibesers (gipcières) 


\section{CHATS ON OLD SHEFFIELD PLATE}

and had maliciously purposed and imagined to sell the same for pure silver in deceit of the people"; both he and a confederate one Michael Hakeneye were sent to Newgate prison. Another case of John of Rochester in I4I4 is recorded where he counterfeited mazer bands in copper and brass, plated over with silver.

It is interesting to read that " no artificer nor another other man shall gild nor silver any such locks, rings, beads, candlesticks, harness for girdles, chalices, hilts nor pommels of swords, powder boxes, nor covers for cups made of copper or latten, upon pain to forfeit to the King one hundred shillings every time, and to make satisfaction to the party grieved for his damages. But that (chalices always excepted) the said artificers may work ornaments for the Church of copper and latten, and the same gild or silver, so that always in the foot or some other part of such ornament the copper and latten shall be plain, that a man may see whereof the thing is made for to eschew the deceit aforesaid."

As to the hall marks on silver $I$ the series of Acts of Parliament relating to the assaying, . marking and regulating wrought plate and ascertaining the standard "for the good and safety of the public," covers a long period. British rall marks possess a reputation extending over three hundred years. Heavy penalties were exacted for fabrication of marks. In France in I724 an

- See Chats on Old Silver, by Arthur Hayden, pp. 25-63. 


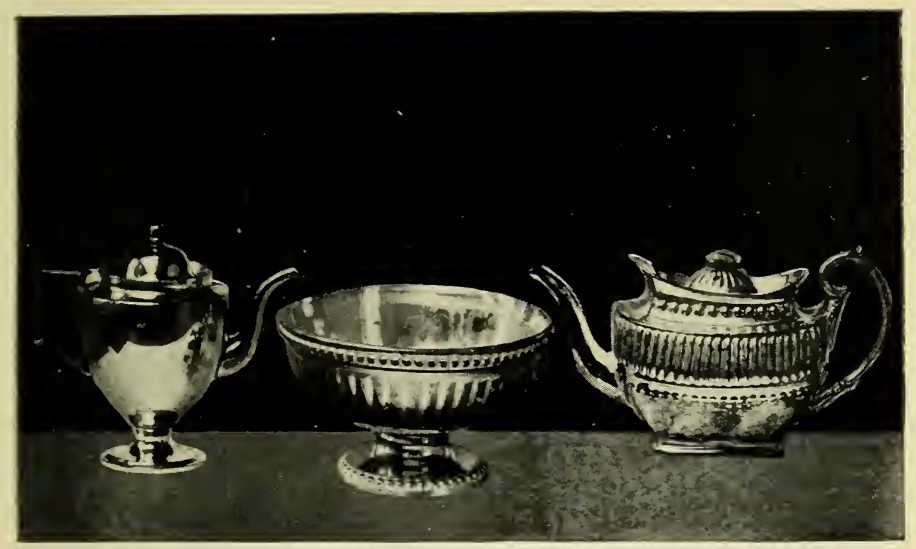

GROUP OF SILVER LUSTRE WARE.

Coffee Pot. Basin.

Teapot.

The Staffordshire potter's imitation of silver.

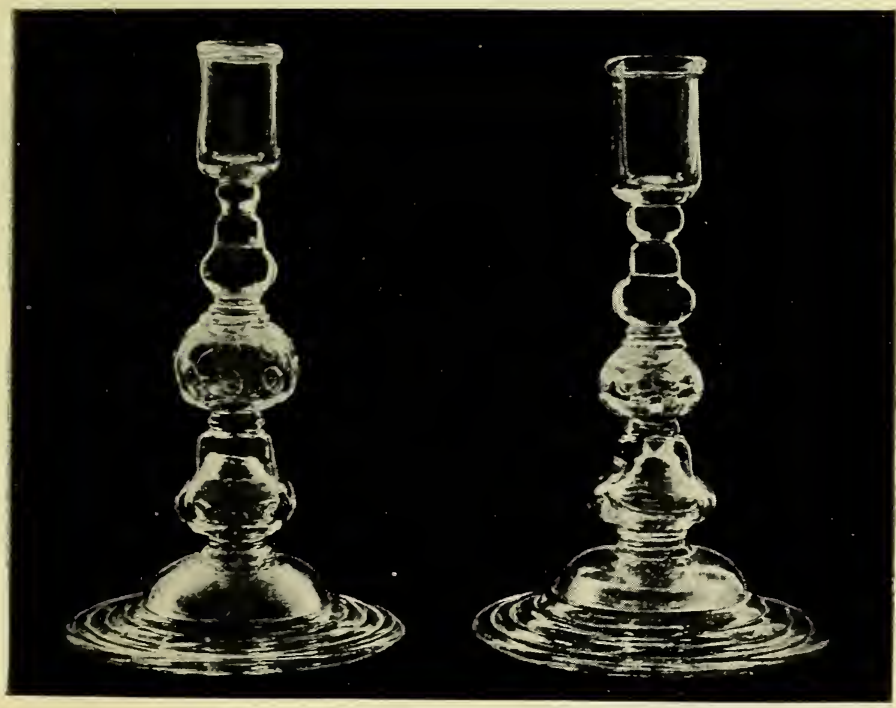

GLASS CANDI.ESTICKS.

Late eighteenth century. 

edict was passed declaring sentence of death against those who counterfeited stamps or insert or solder stamps on other plate.

It is thus evident that baser metals had from time immemorial been plated with silver, and, given an unprotected public, many such frauds could be perpetrated by skilful and unscrupulous craftsmen. In fact they were perpetrated. In I767 a working silversmith was prosecuted by indictment upon Stat. XXVIII Edward I and Stat. VI George I, cap. II for soldering bits of standard silver to tea-tongs and shoe-buckles which were worse than standard and sending the same to the Goldsmiths' Company Assay Office at London in order fraudulently to obtain their marks to the same. In France from I753 to I759 a set of regulations to be observed by silversmiths in the profession of their art enacts that " They shall not make the rims turned over full of solder, in form of hammered edges to basins, dishes and plates; nor shall they under pretext of joining, solder on to them other bottoms."

The methods employed prior to the invention of the plating by fusion and rolling in sheets at Sheffield was known as French plating. Throughout the eighteenth century clock cases were silvered by this method, and successive layers of silver could be applied to any thickness required.

Silver Platers at Sheffield.-The platers set out frankly as a school of copyists to imitate silver plate. They laid a thin imposition of 


\section{CHATS ON OLD SHEFFIELD PLATE}

silver on copper and rolled it and dealt with the sheets as if they were solid silver. They suffered from many diasadvantages which they eventually overcame; they competed directly, and more directly, than did the Staffordshire potters with the silversmiths. The potter snatched the silver models and so did they. But he had less reason than they because he left his proper technique as a worker in clay in so doing. It was no new thing to plate baser metals with silver or with gold. But the method by which it was accomplished and the rolled-out sheets were new. To rush into a general industry to expend great capital on it, to launch it on the market, to compete with the richest and closest corporation of goldsmiths in the world, was a new and audacious venture, and this Sheffield did, and the designs partook of the character of the finest produced by the experienced workers in silver plate.

It is an incongruous situation wherein this school of imitators, who set out diffidently to simulate silver and were presently met by severe statutes of the realm and with severe penalties for producing marks simulating those of the assay offices, overrode the tide that set against them and were finally acknowledged by statute as genuine craftsmen to be protected in a great industry, and Sheffield obtained an assay office of her own, with overlordship over her platers.

In comparison with the other assay offices both Sheffield and Birmingham own titles which 
seem to convey that the assay offices came into being as a protective measure; they were to be watch-dogs over the silver platers in their district. In 1773 there were, among others, the "Wardens and Commonalty of the Mystery of Goldsmiths of the City of London," the "Incorporation of Goldsmiths" of Edinburgh, and the "Fraternity or Company of Goldsmiths" of Dublin. But the assay offices established at Sheffield and Birmingham were to be "The Guardians of the Standard of Wrought Plate," which is suggestive in the circumstances.

Competitive rivalry in art has often ended in the undoing of a particular school where imitation was pushed to fulsome lengths. When the wood engraver simulated the actual cracks in the canvases of the subjects he was copying on his block he showed a decadence which shortly led to his extinction. But the Sheffield platers never added blemishes of their own to the silver they copied. They produced faithful copies. They selected fine examples and they stood supreme in what they set out to do, until, by a later process, they were superseded. 



\section{II}

\section{EARLY DAYS}

THE INVENTION OF SILVER PLATING BY FUSION

THOMAS BOULSOVER OF SHEFFIELD (17041788)

A WORLD OF KNICK-KNACKS

THE SHEFFIELD SILVER-PLATING PROCESS

EARLY SHEFFIELD PLATED PRODUCTIONS

JOSEPH HANCOCK

THE RISE OF THE BIRMINGHAM AND OTHER SILVER PLATERS

THE COMMENCEMENT OF THE GREAT PERIOD OF SHEFFIELD PLATING

CONTEMPORARY SILVERSMITHS AND THEIR ART 

CHAPTER II

\section{EARLY DAYS}

The invention of silver plating by fusion-Thomas Boulsover of Sheffield (1704-1788)-A world of knick-knacks-The Sheffield silver-plating processEarly Sheffield plated productions-Joseph Hancock -The rise of the Birmingham and other silver platers-The commencement of the great period of Sheffield plating-Contemporary silversmiths and their art.

IT was in the year I743 that a fortunate accident led to the discovery that copper and silver could be fused together, and happily the value of the momentary happening led to the further development of the process and the final perfected invention of plating silver on copper which laid the foundation of a great and flourishing art industry which brought wealth and renown to Sheffield and extended to other centres. The old method of plating continued with various improvements for a hundred years until superseded. During the years I750 to I790 some of the best examples were issued and a stream of fine work duplicating the silver plate of the period, and not excluding examples simulating earlier Queen 


\section{CHATS ON OLD SHEFFIELD PLATE}

Anne styles, was poured out. Its excellence of craftsmanship and its cheapness not only won the approval of the English public but attracted the attention of Continental buyers, and contemporary with the catalogues of Joseph Wedgwood issued in French and other languages we find that the Sheffield and Birmingham silver platers similarly issued illustrated catalogues with designs showing what they were producing.

\section{Thomas Boulsover of Sheffield (1704-1788).} -According to some accounts Thomas Boulsover was a button maker, a spur maker or a cutler, probably he was all three, and employed in the making of these and other metal articles then manufactured at Sheffield. $\mathrm{He}$ is spoken of as an "ingenious mechanic." $\mathrm{He}$ was probably a practical workman who had a small shop where articles were brought for repair. It was in connection with the repair of a knife handle which was partly copper and partly silver that owing to an accident in the soldering the copper and the silver fused together. Although to his credit he immediately realized the possibilities of his discovery, he was possibly too poor a man to do more than carry out further experiments in a small way and make buttons and snuff boxes and minor articles by his process. His name is sometimes spelt as Bolsover, but it would appear that in the records at Sheffield he registered under the name of Thomas Boulsover and Co., which is possibly more correct; although in days when 
duchesses spelled their title as " dutchess " matters of a letter or two were not considered very important even in names.

The following extract from the Derby Mercury, September I7, I788, is an interesting obituary notice of Boulsover:

" On Thursday se'night died at Whitely Wood, near Sheffield, Mr. Thomas Bolsover aged eightyfour. This Gentleman was the first Inventor of Plated Metal: which like many other curious Arts was discovered by Accident. About the year I750 (at which Time he kept a Cutler's Shop at Sheffield), Mr. Bolsover was employed to repair a Knife Haft which was composed of Silver and Copper ; and having effected the Job, the cementing of the two Metals immediately struck him with the practicability of manufacturing Plated Articles, and he presently commenced a Manufacture of plated Snuff Boxes and Buttons. Consequently from Mr. Bolsover's accidental Acquirement, the beneficial and extensive Trade of plated goods had its origin. He has been justly esteemed one of the most ingenious Mechanics that Sheffield can boast." The name Bolsover, says the writer in the Derby Mercury, suggests a Derbyshire origin.

There is little doubt that among the earliest articles to which Boulsover turned his attention were buttons. Silver was in the time of Boulsover being sold at approximately six shillings per oz., and, in view of the cost of solid silver articles, the invention of a presentable process that would 


\section{CHATS ON OLD SHEFFIELD PLATE}

lessen the cost came at an opportune moment. It must be remembered, too, that there was a duty of sixpence per ounce upon silver. In I784 there was an additional duty of sixpence imposed. In 1804 the duty was increased to one shilling and sixpence per ounce, and it is interesting to note that in I8I5 by 55 George III, cap. I85 the counterfeiting of the King's head duty mark was made a felony punishable by death. Nor did the invention, although coming at a ripe moment when economies were desirable, seem likely to receive financial support; - for the establishment of an industry on a great basis, for the very same motives which necessitated economy, prevented capital from being embarked on what might have been a hazardous enterprise. At that time the country was in a disturbed condition. In I742 Walpole's administration came to an end. His fall was occasioned by his foreign policy, which was based on friendship with France. He was succeeded by Carteret. His "Drunken Administration," as it was termed, was not likely to instil confidence in the country. He cared solely for foreign politics. "What is it to me," he said, "who is judge, or who is bishop. It is my business to make kings and emperors and to maintain the balance of Europe." In I744 France declared war against England, and preparations for war were made in America and India. In I745 Prince Charles Edward Stuart, the Young Pretender, landed in Scotland, was given a public 
banquet by the ladies of Edinburgh, defeated Sir John Cope at Prestonpans, and marched across the border and through England as far as Derby. His troops must have passed through Sheffield, and with civil war in the heart of the country, and at his threshold, Boulsover no doubt quietly pursued his vocation and added to his experiments. He made snuff boxes and buttons, and patch boxes, and possibly buckles, and waited for a better day.

It is interesting to notice the inauguration of our two great china factories about this date. Derby was not likely to commence a new industry with the Pretender rattling his sabre in the city in I745. But we find Worcester commencing operations in I75I, followed by Derby in 1756 . There is stated to have been a political significance in the advent of the former. It appears that in the cathedral city in spite of its loyalty to the reigning house there was a growing Jacobite influence. It was thought that the establishment of a factory would enable the Whigs to win the election contests which had gone to the Jacobite party. But we do not remember to have heard any such association with Sheffield in regard to the establishment of the Sheffield plating industry. It seems to have been purely a trade venture and supported by local influence and capital.

It is not generally known that for a long period Sheffield has made use of Swedish iron for the manufacture of the best steel. Nor is it public 


\section{CHATS ON OLD SHEFFIELD PLATE}

property that "Made in Sheffield" frequently meant that razors, knives, surgical instruments, scissors, etc., were made at Solingen in Germany, and sent as "blanks" to be finished in Sheffield. The Master Cutlers of Sheffield cannot have been aware of these happenings. We speak of pre-war days when we have seen at Solingen much that should shame Sheffield.

In the early knife handles illustrated (p. 5I) the sheet is very thin, and the design is stamped and both halves of the handle soldered together. The thin pointed steel blade is characteristic of old examples. It had not yet arrived to the stage of the trade mark with name of firm " made in Sheffield." There is a fault in design. The object of ornament is to be seen and admired. When these knives were set on a table, the head of Shakespeare in the medallion was upside down. This is a small detail, but details such as these were carefully studied at Sheffield at a later date and ornament used to its fullest capacity.

In regard to the particular design of the head of Shakespeare. There is a reason for its existence. It comes straight from the days of the great Shakesperian revival by David Garrick, where in I74I he acted Richard III for the first time. Quin and Cibber were outshone by this new actor, who drew the fashionable world of St. James's to his little house in Goodman's Fields. $\mathrm{He}$ became an idol. In I742 with Mrs. Woffington he acted in Dublin for a season and 

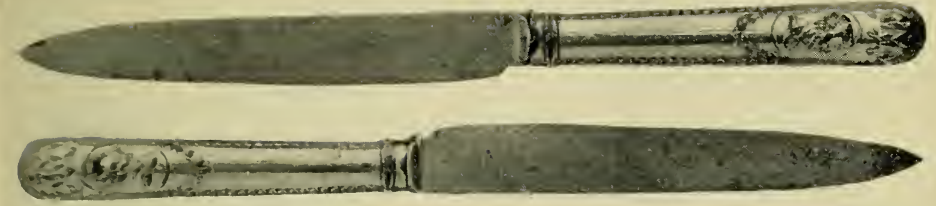

1

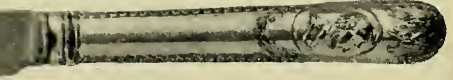

OLD SHEFFIELD KNIVES.

With steel blades and plated handles with medallion of Shakespeare.
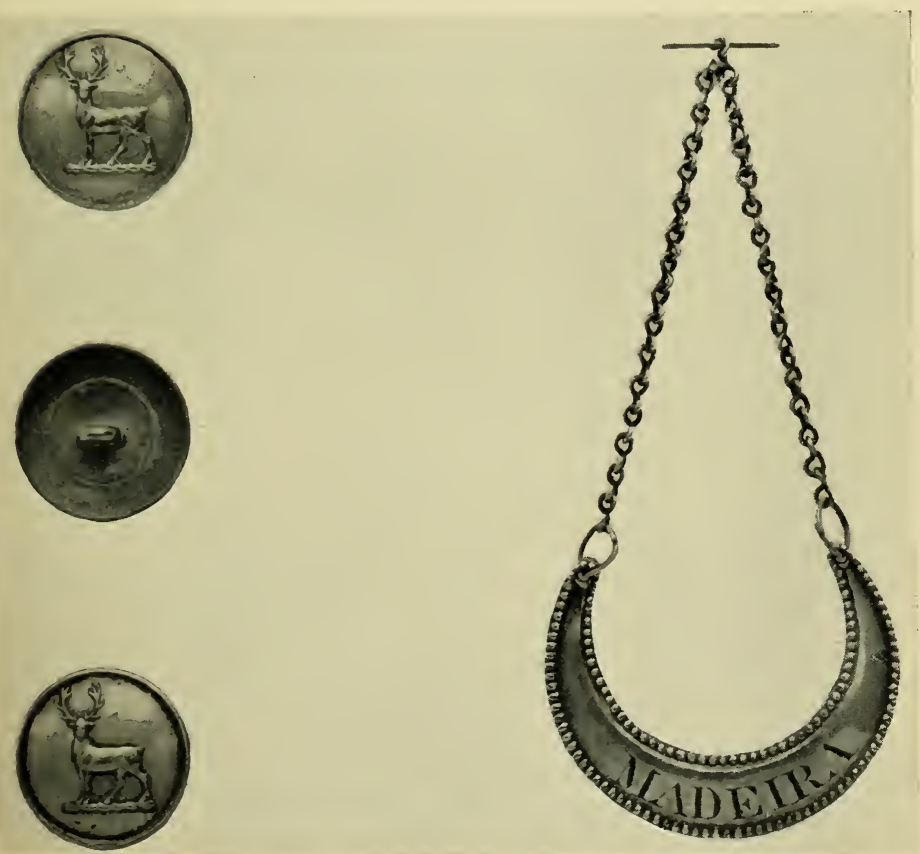

OI.D SHIFFIELD PLATED BUTTONS.

OLD SHEFFIELD PLATED WINE LABEL.

(In the collection of B. B. Harrison, Esq.) 

created a great sensation. In 1747 he was joint lessee of Drury Lane Theatre. A Chelsea figure represents him as Richard III and, in complement to the new worship of Shakespeare who had been forgotten for a hundred years. Addison had omitted him from his "Account of the greatest English poets," and Steele did not include him in his essay "A Dream of Parnassus" in the Spectator. Sheffield, quick to seize an idea of marketable value, stamped the little medallion of Shakespeare on her knife handle with an eye to fashionable demands of the day.

Buttons were also a strong feature in early days, and continued as a leading feature to the end of the Sheffield plated period. Firms were established in London who carried on this branch till quite a late date. It is stated that a plated button was the first article made by Boulsover. In Ireland John Roche, of Usher's Quay, Dublin, also produced buttons in this style. The designs were stamped according to order. The illustration (p. 5I) shows the type with copper shank firmly soldered on to the back. Possibly Army buttons of the same date were similarly made. Collectors have a field here for search and research.

Wine labels, or as they were termed, " bottle tickets," offer, if not great variety of style of decoration, certain curious indications as to the wines and liqueurs they were intended to label. We illustrate a label used for "Madeira." But some of the others were for wines either 


\section{CHATS ON OLD SHEFFIELD PLATE}

now known under more familiar names or forgotten altogether, such as: "Shrub," "Bucellas," "Xerez," and others.

The patch boxes (illustrated, p. 55) show the type of work executed in the early days. The plating was carried out on the exterior; the interior of these examples is bare copper. The left-hand example shows in its ornament the swirls and curves of the rococo style which Chippendale adapted and spiritualized in its translation. The right-hand specimen owes something to Dutch influence and to tobacco boxes which were common at the period. 'It is a genre subject, with the figure of a man standing and a lady reclining on a sofa. The middle patch box is in tortoiseshell and silver, and represents the fable of the Fox and the Crane. The sides and base of this box are plated, and, as in the case of the others, the interior is copper.

A World of Knick-knacks. - The world of London and Bath had set the fashion in trinkets, as much affected by the masculine sex as by ladies of fashion. Buckles, clasps, etuis, snuff boxes were made in gold or silver gilt. But one Christopher Pinchbeck, who died in I732, a "Clock and Watchmaker and Toyman," as he terms himself on his trade card with his engraved portrait, became a specialist in reproductions and replicas. It is of interest to quote the advertisement of the son of Pinchbeck in the Daily Post, November I7, I732, as showing 

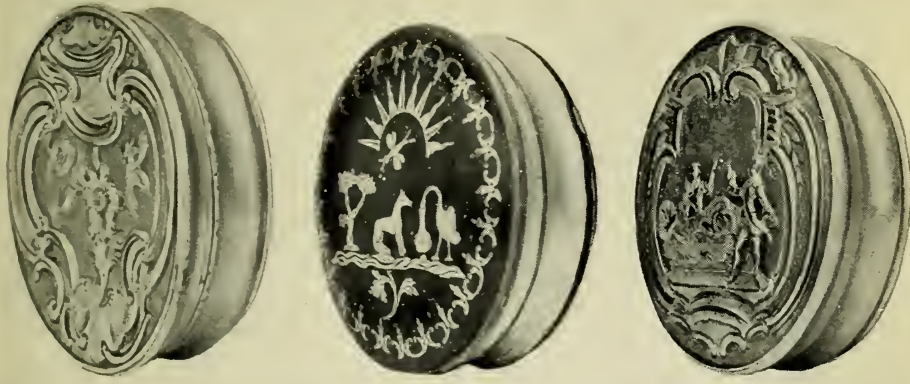

OLD SHEFFIELD PLATED PATCH BOXES.

I. Rococo design with floral ornament. Interior of box copper.
2. Tortoiseshell, inlaid with silver. Fable subject: Fox and Crane.
3. Rococo border, with figures of man and woman. Interior of box copper.
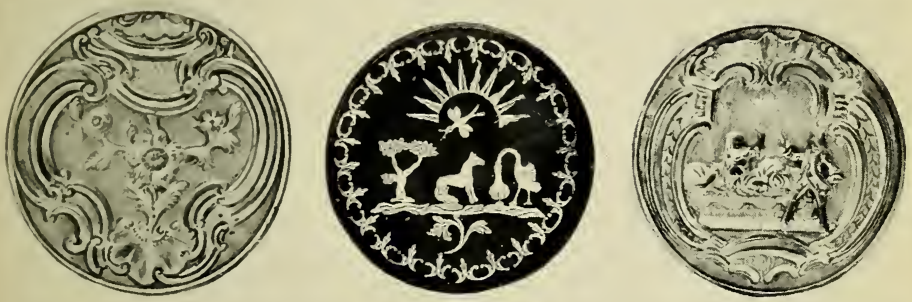

DETAIL OF ABOVE.

(In the collection of B. B. Harrison, Esq.) 

what articles he made of a metal in imitation of gold, and with this as a parallel it will be possible to draw a conclusion as to the class of articles of a similar character which were made at Sheffield at a slightly later period:

"To prevent for the future the gross Imposition that is daily put upon the public by a great Number of Shopkeepers, Hawkers, and Pedlars, in and about this town, Notice is hereby given that the ingenious Mr. Edward Pinchbeck, at the Musical Clock in Fleet Street, does not dispose of one grain of his curious metal, which so nearly resembles Gold in Colour, Smell, and Ductility, to any person whatsoever; nor are the Toys made of the said Metal sold by any one person in England except himself: therefore Gentlemen are desired to beware of Impostors, who frequent Coffee Houses, and expose to sale Toys pretended to be made of this Metal, which is a most notorious Imposition upon the Publick. And Gentlemen and Ladies may be accommodated by the said Mr. Pinchbeck with the following curious Toys, viz. Sword-Hilts, Hangers, CaneHeads, Whip-Handles for Hunting, Spurs, Equipages, Watch Chains, Coat Buttons, Shirt Buttons, Knives and Forks, Spoons, Salvers, Tweezers for Men and Women, Snuff Boxes, Buckles for Ladies' Breasts, Stock Buckles, Shoe Buckles, Knee Buckles, Girdle Buckles, Stock Clasps, Necklaces, Corrals." The advertisement goes on to enumerate "Watches and Astronomical Clocks, which newly 
invented Machines are artfully contrived as to perform on several Instruments great variety of fine Pieces of Musick composed by the most celebrated Masters, with that Exactitude, and in so beautiful a manner that scarce any hand can equal them. They likewise imitate the sweet Harmony of Birds to so great a Perfection as not to be distinguished from Nature itself."

Pinchbeck articles are now collected. They display fine workmanship and artistic decoration, and true to the asservation of the inventor they have kept their colour in a wonderful manner.

The Sheffield Silver Plating Process.-It has been already shown that the superimposition of silver and gold on baser metals was not an unknown thing, and that many old statutes exist to prevent such wares being substituted for solid gold and silver plate. These earlier processes mainly depended on washing or laying on successive sheets or foils. The Boulsover process consisted in cutting off from a solid bar of copper a rectangular piece some three inches wide, twelve inches long, and about one inch in thickness. This was pure soft copper and easy to work. Later an alloy was made with the addition of a sixth part of brass making the base or body harder. One side of this copper block is carefully filed, extreme cleanliness being employed to exclude any dirt from the surface. A silver sheet of slightly lesser dimensions, after being made thoroughly flat 
and kept perfectly clean on one side, is laid on the copper with the two prepared surfaces fitting upon each other. The silver was about a quarter of an inch in thickness. Over the silver is laid a piece of sheet iron the exact size of the silver. The three sheets are then tightly bound together by means of iron wire. The whole is then put into a furnace until it is red hot; at the exact moment when it is considered by the skilled workmen that the two metals had properly fused together the block was carefully taken from the furnace and put aside for cooling. It is obvious that if the workmen were careless and did not by constant practice know the correct length of time to allow the operation to continue in the furnace the result would have been a failure. The silver, instead of exactly fusing with the copper, would run over the edges and leave patches where the two metals had not properly adhered. It is the same in old processes such as the tempering of a sword. There are no exact rules, the craftsman must have a sure eye and be quick to act at a second's notice.

Those who have witnessed the cabinet-maker in the exactitude with which he commands his mastery over glueing parts, as is experienced in the manufacture of air-craft parts, know that given perfect conditions of temperature and glue of indubitable character the parts cannot be separated. Similarly in the Sheffield plating the silver adhered to the copper base and remained 


\section{CHATS ON OLD SHEFFIELD PLATE}

a component part and not a layer likely to be disturbed by future bending or hammering.

The next stage in the process was the process of passing these blocks under steel rollers in the rolling mills. And during this operation it underwent several further stages of heating or annealing. Here again the workman has to ascertain to a nicety the exact moment to discontinue the firing, otherwise all would be ruined and the silver be burnt off the face of the copper. In glass blowing similar technical difficulties render the art one of great rapidity and quick judgment. At the last stage, by an act of misjudgment, all the previous work might be wasted and the piece turn out a wreck. The fire is a capricious agent. In pottery it is the same. Many a vase after being elaborately painted by the artist and fired in the ovens, owing to some accident, comes out a distorted and misshapen mass.

The result of this Sheffield plating was to produce a sheet which could be manipulated in the same manner as though it were solid silver. The interiors of vessels, it is true, showed the copper, but these were tinned till at a later date silver was placed on both sides of the copper and fused at the same operation in the furnace. In regard to the ornament a good deal found on old Sheffield plated ware was made by the use of dies, such as feet, handles, knobs, and were cast in two halves and soldered together prior to being affixed in their positions on the articles. In other forms 
of decoration similar to that found on the silver plate of the day the same technique was employed in the repoussé work in producing a raised design on the exterior, that is, by means of hammering against a sand-bag, using a tool on the inside of the vessel. Chasing and engraving is done on the outside while the vessel is filled with sand or with some other composition.

This technique is not confined to Sheffield plated articles; it is the technique of the silversmith, where repoussé work receives its striking force by a tiny hammer from within the vessel ; chasing with sunk lines, and elaboration and finishing the repoussé design, is done from the exterior.

In regard to designs, the productions duplicate some of the finest plate. At its best Sheffield plate realized its artistic responsibilities. It did not disseminate shoddy imitations of English plate. Its copies had the saving grace of being executed by men who understood the value of the originals. They worked faithfully in a more economic medium, but they did not debase the original design, and they were too clever to add meretricious touches of their own and mar work which they must have loved or they could not have copied it so truly.

Joseph Hancock of Sheffield.-Thomas Boulsover claims our regard for his invention and his steady application to it on a minor plane. But Joseph Hancock took longer views. $\mathrm{He}$ was a member of the Corporation of Cutlers in Sheffield, 


\section{CHATS ON OLD SHEFFIELD PLATE}

and he it was who saw to what great uses the new invention could be put if handled on a great scale. He made candlesticks, teapots, salvers, and many other more important articles, and by so doing he raised the process above the snuffbox and button level and established commercially the great industry for which Sheffield has become famous.

Mills were erected for rolling out the ingots, skilled workmen were procured who had served their apprenticeship as silversmiths in London and elsewhere. Sheffield, almost .concurrently with the great impetus given to the making of plated silver ware, began to make silver plate. But such solid silver had to be conveyed to London to receive the marks of the Goldsmiths Company of London to denote its standard quality. In regard to embarking on so novel an enterprise as raising a great industry founded on the designs of the silversmiths, there must have been many forebodings as to legal possibilities. The laws on the subject were very stringent. Persons had been fined and imprisoned in the reign of George II for manufacturing plate of lower value than the standard. In I74I one Drew Drury of London stated that he was inadvertently concerned in making a stamp resembling the "Lion Passant," that he had never made any use of it, and that he had caused it to be broken. The Wardens of the Goldsmiths Company did not accept his confession and proceeded against him. 
Among exceptions not required to be assayed were metal spouts to china, stone or earthenware teapots and shirt buckles or brooches. But silver shoe-clasps, patch boxes, salt shovels, tea strainers, caddy spoons, bottle tickets (wine labels), and all buckles except the above mentioned were, if silver, to be assayed.

It is remarkable to find the Sheffield silver platers somewhat incautiously flying in the face of the protective legislation in regard to silver plate and its marking. In fact, it appears that they recklessly placed three marks on some of the earlier ware resembling those on silver plate. In 1773 a Committee of the House of Commons was appointed to inquire into the manner of conducting the several assay offices in London, York, Exeter, Chester, Norwich, and Newcastleupon-Tyne. York, Exeter, and Norwich, it was found, were not in operation and had closed down. In regard to evidence a Mr. W. Hancock, a silversmith of Sheffield, said that his work had been injured by scraping. He went to the Goldsmiths Hall of London and "gave some drink to the Assay Master and scraper, since which time his plate had been less damaged." Mr. Spilsbury said that scrapers had the opportunity to deliver to the assayer better silver than they scrape from the work, and that the assayer had the opportunity of favouring what silversmith he pleased. When his plate had been objected to he found that these difficulties were removed 


\section{CHATS ON OLD SHEFFIELD PLATE}

on "giving drink at the Hall." This may be said to have been in keeping with the old tradition of the Goldsmiths Company of London, for we read that in 1359 one of the members of the Fellowship was found guilty of mals outrages. He prayed the mercy of the Company and offered them ten tuns of wine. $\mathrm{He}$ was duly forgiven on paying for a pipe of wine and twelve pence a week for one year to a poor man of the Company.

The Committee in their Report found in regard to Sheffield and probably Birmingham that " the artificers are now arrived at so great. a perfection in plating with silver the goods made of base metal, that they very much resemble solid silver, and that if the practice which has been introduced of putting marks upon them somewhat resembling those used at the assay offices shall not be restrained, many frauds and impositions may be committed upon the public."

The result was to draw the teeth of the platers by appointing assay offices at Sheffield and Birmingham. The penalties laid down in the Act of I773 put an end to silver plate being marked. In I784 another Act was passed, 24 George III, cap. 20, which had some interesting stipulations concerning silver plated ware. "Whereas doubts have arisen whether a Manufacturer of Goods plated with Silver can make or strike his Name upon such Goods without incurring the said Penalty (one hundred pounds): and by reason of such Doubts the Manufacturers of Goods plated 


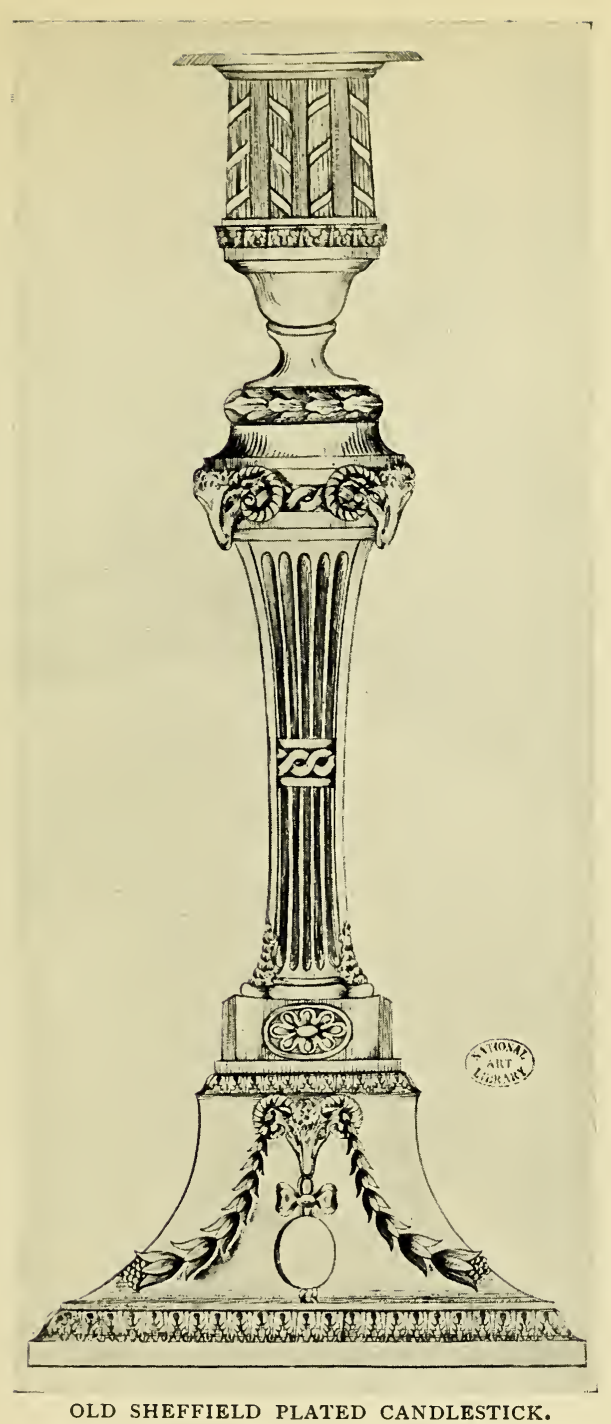

Designed in Adam style, 1775. From copper-plate engraving in old catalogue issued by Sheffield makers to the Continental markets.

(At the Victoria and Albert Museum.)

(Keproduced by permission of the Board of Education.) 

with Silver have been deterred from striking their Names upon plated Goods, whereby a proper Distinction betwixt plated Goods of the different Manufacturers is prevented, and all Emulation in that Branch of Business is destroyed: to the certain and manifest Prejudice of the said Manufactory. For obviating such Doubts be it further enacted by the Authority aforesaid, that it shall be lawful for any Manufacturer of Goods plated with Silver within the said town of Sheffield, or within One Hundred Miles thereof, to strike or cause to be struck upon any Metal Vessel or Thing plated or covered with Silver, his or her Surname, or, in case of any Partnership the name of the Firm of such Partnership, and also some Mark, Figure, or Device, to be struck at the end of such Surname, or other Name of Firm: such Mark, Figure or Device not being the same or in Imitation of any Mark made use of by any Assay Office established by Law for assaying wrought Plate, without being subjected to any Penalty or Forfeiture for so doing; any Thing in the said Act to the contrary hereof notwithstanding."

A later clause lays it down that "it shall be Provided that every such Surname or Name or Firm as aforesaid, shall be in plain and legible characters, and struck with one Punch only."

The clause "within one hundred miles of Sheffield" included Birmingham, which gave a control to Sheffield; but the severe rules as to stamps being the surname or name of the firm 


\section{CHATS ON OLD SHEFFIELD PLATE}

made the marking of Sheffield plated articles a cumbrous business and not much to the liking of the silver platers, although it must be regarded as a compliment that they were legally compelled to mark their ware so carefully, apparently for no other reason than that its resemblance to silver plate was so strong that it might be mistaken for the sterling article.

The Rise of the Birmingham and Other Silver Platers. - What Joseph Hancock did for Sheffield Matthew Boulton did for Birmingham. Prior to I773 the mark used consisted of three stamps with two crowns and the letters $B \& F$ (Boulton and Fothergill); in I784 the mark was two suns struck in duplicate and was registered as M. Boulton and Co. at the Sheffield Assay Office in accordance with the Act of I784.

The I773 Act (I3 George III, cap. 52) made no provision for the Sheffield and Birmingham platers, but gave powers to the Sheffield and Birmingham Assay Offices. Certain portions of this were repealed, and provision made for the marking of plated ware. But this revision only applied to Sheffield and for some reason Birmingham was omitted, therefore the Birmingham platers, although silver could be assayed at Birmingham, had to put themselves under the ægis of the Sheffield Assay Office. Hence we find Boulton \& Co. registering at Sheffield.

At Nottingham the silver plating industry was established, and in London it obtained so great 


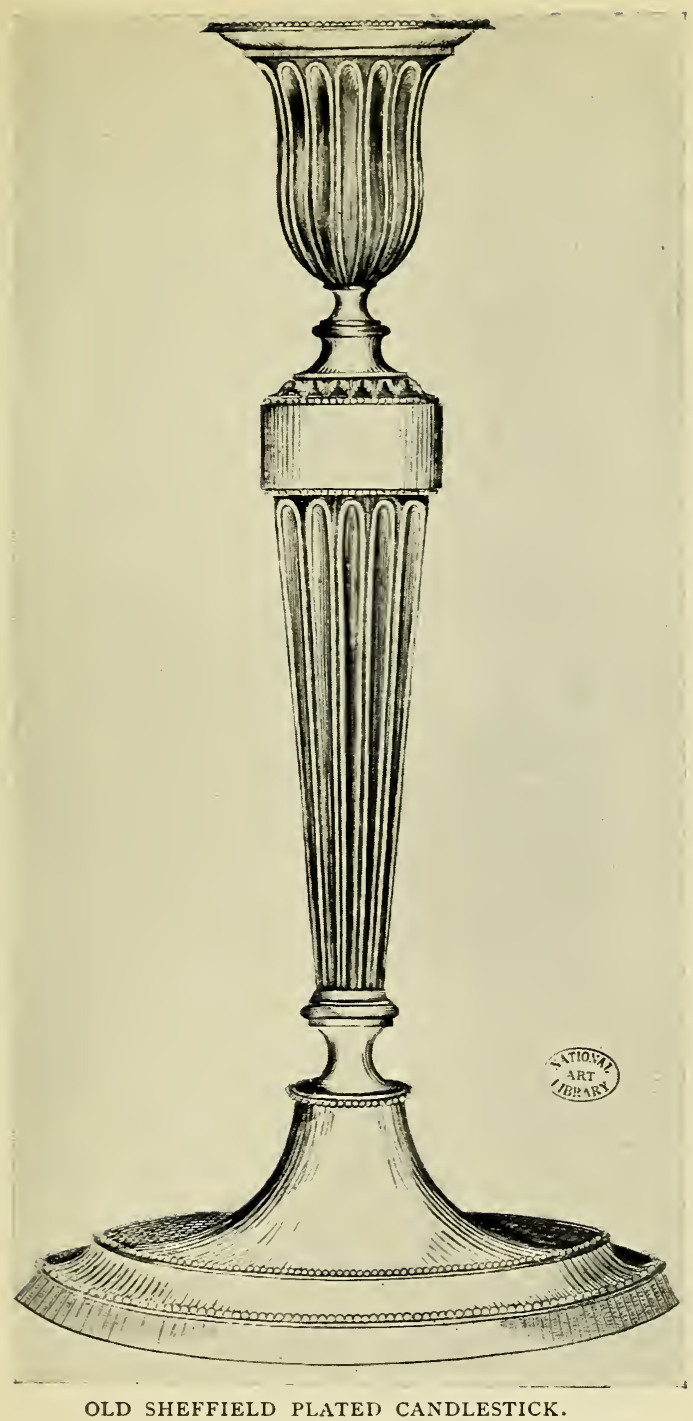

From copper-plate engraving issued by eighteenth-century Sheffield plate makers to the Continental markets. Date 1795.

(At the Vicloria and Albert Museum.) (Reproduced by permission of the Board of Education.) 

a stronghold that although it was born in Sheffield it died in London, as the craftsmen, although they found themselves somewhat moribund and a gradually dwindling body, owing to the newest invention from Sheffield-plating by electro-process-held on until some years after the new invention had extinguished the older styles elsewhere, but in the end silver plating by fusion and rolled plate work succumbed.

In regard to Ireland there is some evidence that an attempt was made to manufacture silver plate by fusion and rolling in the Sheffield manner. But very little fused plated ware was actually made in Dublin. Certain premiums were offered by the Irish government for " light plate" made in that country. Light plate evidently being understood to be plated ware. There are numerous notices and advertisements in Irish newspapers from about I760 onwards announcing imports of Sheffield plated goods. There is no doubt that a considerable amount of Sheffield plated ware was imported into Ireland. The records of one firm show that between 1784 and I804 plated articles to the value of $£ 60,000$ were exported from Sheffield to Ireland. Although the Dublin directories of the period show many names of Irish "silver platers," this is not evidence enough to establish the fact that any of these craftsmen worked in rolled plate; there is every likelihood that they plated small articles in the old manner and later, after the early years of the nineteenth 
century, with the process known as " close plating." The name "Sly. Dublin" appears on a steel meat skewer plated with silver belonging to these latter days. There is, too, the possibility that some of the Sheffield platers actually exported rolled plate in sheets, though there is no direct evidence of this, as it would have been somewhat suicidal to place in the hands of other artificers the material to convert into what would have been practically Sheffield plated ware although made elsewhere.

But there is confirmation, although somewhat meagre, that plating by fusion was accomplished at Dublin, though apparently only practised to a small extent.

In 1779 the Goldsmiths Company of Dublin complained of the great amount of plated goods imported, and in $I 783$ the Dublin Society offered a premium of $£$ I50, being at the rate of 6 per cent. on value of Irish plate and light plated goods manufactured in Ireland, by rollers, between I782-3 and $1783-4$.

The records show that on November 25, I784, the sum of $£^{24} 7 \mathrm{~s}$. was awarded to Christopher Haynes, goldsmith, of Dublin, being at the rate of 6 per cent. on the value of light plate goods entirely manufactured by him in Ireland by rollers, from Ist July, I783, to Ist July, I784; value $£ 405$ I7s. $3 \mathrm{~d}$. It is further noted that a premium of $£$ II I7s. 4d. was paid to John Lloyd, goldsmith, of Harolds Cross, Dublin, being 6 per 
cent. on value of light plated goods manufactured by him in Ireland by rollers, value $£$ I97 3s. 3d. ; and also premium of $£^{2}$ 2s. IId. being 6 per cent. on value of plated goods manufactured by him in Ireland by rollers, value $£ 35$ Ios. In I792 "A Company of Manufacturers" in Abbey Street, Dublin, advertise plated metal for Button Makers at 4s. 4d. per pound.

The Great Period of Silver Plating.-Contemporary with the growth of Sheffield plating were influences which were very stimulating in regard to the fine and the applied arts. The quarter of a century from I765 to I790 teems with rich inventiveness on every hand. In I768 Sir Joshua Reynolds became the first President of the Royal Academy, and he died in I792. His brilliant canvases, with their Titian colours, and his children as graceful as those of Correggio, brought noonday into English art. Thomas Chippendale's Director was published in I754, and the translations of great French styles acclimatized in this country. Horace Walpole built Strawberry Hill in I750. In I793 Sheraton's Cabinet Maker's and Upholsterer's Drawing Book appeared. Between these points a great influx of ornament and design burst upon the country. Flaxman was holding a mirror to the classic graces and Wedgwood was translating them into clay. Brothers Adam classicized certain parts of London. The Adelphi is typical. David Garrick lived in the Adelphi Terrace; 


\section{CHATS ON OLD SHEFFIELD PLATE}

Antonio Zucchi painted his drawing-room ceiling, and a white marble mantelpiece chimney piece cost three hundred pounds. Great engravers were working in mezzotint and in line : stipple engravers under Bartolozzi's influence produced gems of English art printed in colours. A great outburst of work of permanent artistic quality stamps the period. Nor were the silversmiths behind in perpetuating glorious designs. Here then was the fine field in which the Sheffield platers could browse for inspiration. Their results justify their existence.

How great the industry became is reflected by the series of Design Books issued showing the patterns that Sheffield was able during a period of training of less than twenty years to send to the Continent and that, be it noted, in the days of Louis Seize. The illustrations of Candlesticks from these Design Books illustrated (pp. 65, $69,75)$, are described in detail in Chapter III in relation to their technique and artistic features (pp. 86, 89).

Contemporary Silversmiths and Their Art.For ten years of the reign of George II, and from I760 to for thirty years of the reign of George III, English plate is remarkable for simple and practical designs embracing the exuberant ornament from the hand of Paul Lamerie and imbued with the classic spirit of Robert Adam. Its variety is a noticeable characteristic, and silver plated replicas carry on the tradition until the second 


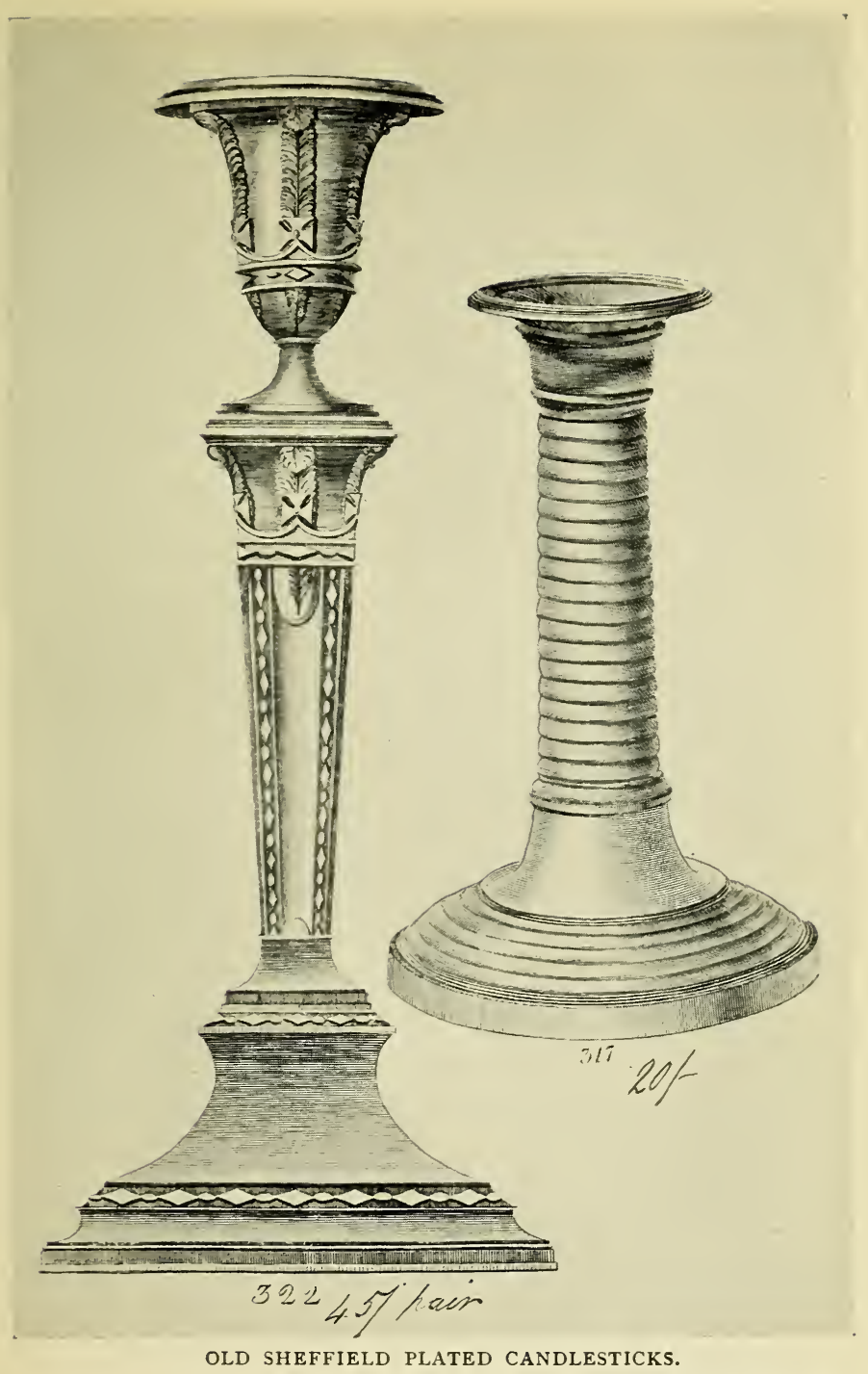

From old Pattern Book issued by R. C. \& Co. (Robert Cadman \& Co.) about 1797. The prices of the above examples (written in ink) are given at $20 \mathrm{~s}$. and $45 \mathrm{~s}$. per pair.

(A: the Victoria and Albert Museum.) (Reproduced by permission of the Board of Education.) 

or decadent period when cumbersome and unwieldy design overloaded ornament, and finicking details choked the fine inspirations that had come down from the past.

The cherubs' heads, the satyrs, the lion-masks, and the engraved and pierced work of Paul Lamerie extended from I742. Thomas Gilpin was noted for his fine scrollwork; Peter Taylor has fine designs embodied in tea caddies engraved with Chinese figures and embellished with shell ornament. Isaac Duke with his sauce boats with handles formed as dragons and rich chasing and ornament holds high reputation. John Cafe, Edward Wakelin, John Swift and George Wickes all were of the middle eighteenth century and are well known. Daniells, William Shaw in I785, Orlando Jackson and James Wilkes carried on the traditions. Peter Archambo, who worked a decade or two previously, had left a technique. The designs of Elston of Exeter are still honoured. At Dublin, R. Calderwood in I750 and William Homer, of Dublin, and John Williams, of Cork, twenty years later were producing masterpieces of delicate artistry. And before the decadence came William Plummer and Paul Storr. It was therefore with no misgiving as to choice of rare design that the Sheffield plate workers set out to immortalize the work of these men with no less courage than did McArdell and the great school of mezzotinters in regard to the canvases of Sir Joshua Reynolds. 

III

\section{CANDELABRA AND CANDLESTICKS}

\section{EARLY TYPES}

THE ADAM STYLE AND ITS PROMULGATION TO THE CONTINENT

THE CANDELABRUM

THE VARIETIES OF THE SPIRAL FORM

THE TRI-FORM CANDELABRUM

THE CHAMBER CANDLESTICK

THE EVOLUTION OF THE TABLE CANDLESTICK 



\section{CANDELABRA AND CANDLESTICKS}

Early types-The Adam style and its promulgation to the Continent-The candelabrum-The varieties of the spiral form-The tri-form candelabrum-The chamber candlestick-The evolution of the table candlestick.

IN commenting upon early types of Sheffield plated candlesticks a good deal of past history has to go by the board. One does not need to discuss pricket candlesticks of ecclesiastical form. Unfortunately the exquisite Stuart examples, the symmetrically ideal forms of the Charles I period, so rarely found, and the finely balanced types of the Charles II, James II and the William period pass-as they were never duplicated by Sheffield.

Sheffield commences with George II and Sheffield ended with George III. Happily the banalities of the early-Victoria era never encompassed her craftsmen. Therefore, the early types of candlestick belong to the days of George II. They belong to the days when Boulsover looked to Joseph Hancock, the master cutler, for inspiration, and Joseph Hancock the cutler of Sheffield set out on a true path. A certain modernity was in 


\section{CHATS ON OLD SHEFFIELD PLATE}

the air. The year I75I had only 282 days, and the year I752 only 355. The calendar was in process of reform. Joseph Hancock's types of the early days (we are speaking of I750 to I765) must have been the ordinary types made by the great silversmiths, though it may be imagined, as though in leading strings, Sheffield gently pursued her way with experimental copying.

To come to technique there were the edges of the silver and copper plate, an ugly witness of inferiority. These must be hidden somehow by godrooned edges, of solid silver maybe, rather than show the poverty of the rolled plate. If they were cast then there were the seams to screen from common observation. To this day the seams denote the genuineness of the old plate. Dies came into being. Portions were cast, ornaments were soldered together and attached to the article. At first there was always the factor determinable enough by close inspection that the silver was only on one side of the copper. The interior of vessels was copper, which was tinned. In candlesticks this was not a very formidable obstacle to successful imitation, as the nozzles could be French plated and otherwise concealed. The bottom could be plugged with a mahogany post and filled with solder, could be covered with shellac at the base and have a fine baize screen from all obtrusive gazers. But Sheffield soon got above and beyond any of these artifices.

It is curious how collectors have come to love 


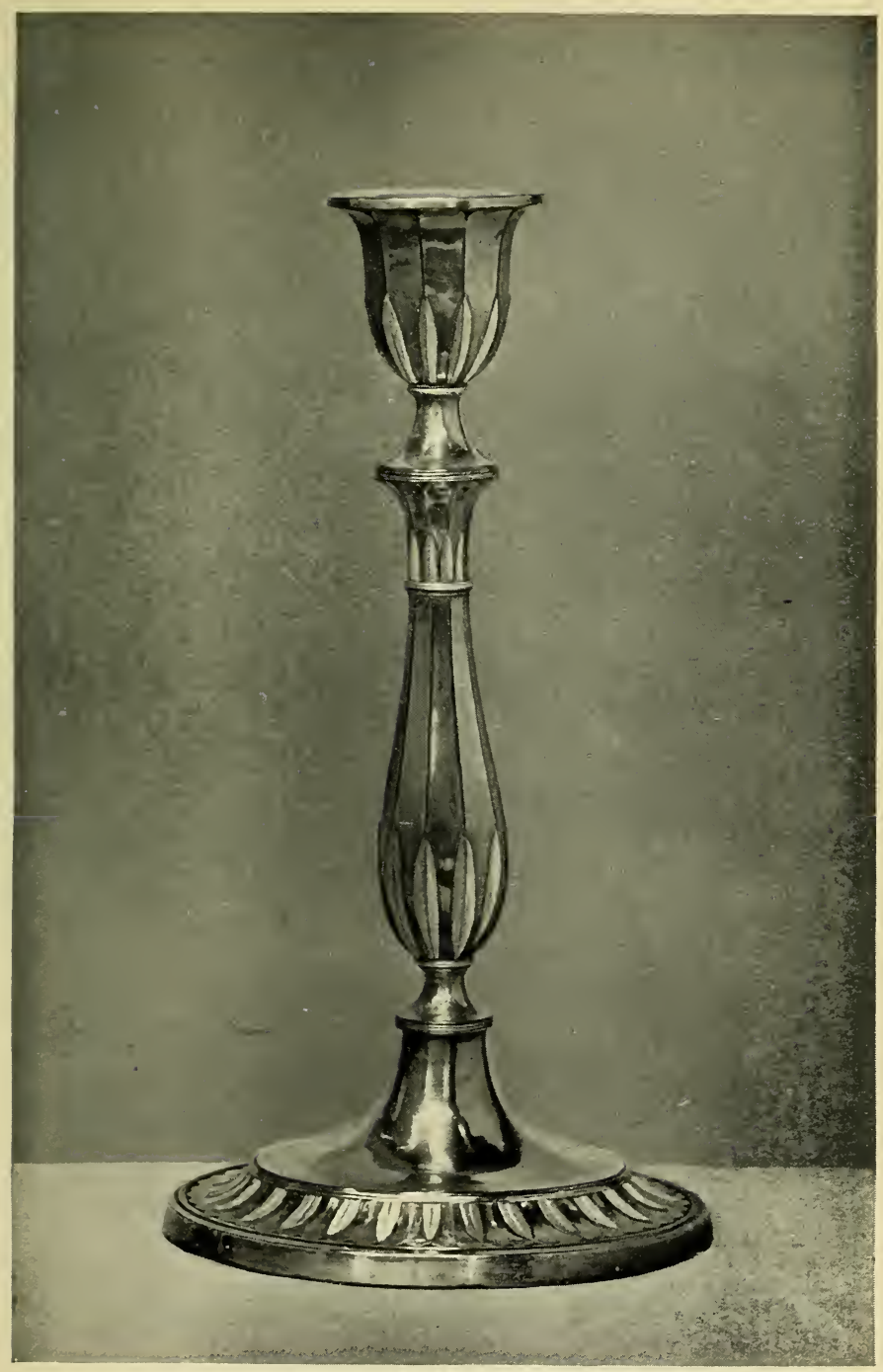

OLD SHEFFIELD PLATED CANDLESTICK.

One of a pair, with finely shaped facets, decorated with leaf ornament. Date $\mathbf{1 7} \mathbf{3}$. (In the possession of G. H. Wallis, Esq., F.S.A.) 



\section{CANDELABRA AND CANDLESTICKS 85}

the candlestick, possibly it is because it represents something that vanished during the horrible era of the gas chandelier and the paraffin lamp, and has been resuscitated in later days in the form of an electric chandelier or in electric standards. Electricity has galvanized the old candlestick and the antique candelabrum into life. The Dutch hanging brass pendants are now one of the stock lines of the electric fitter who furnishes the villa in pseudo-Jacobean or pseudo-Georgian style. The shopwalker or his satellites will pronounce empirically upon styles with the surety of an encyclopædia. In consequence all electric lights are hall-marked with "periods": they are "Adams" (sic), or "Chippendale," or " Sheraton." Possibly collectors of another age may find shoddy written over a lengthy period of our modern fitments for illumination.

\section{The Adam Style and its Promulgation.-} That Sheffield did great things in candlesticks is shown by a visit to the Victoria and Albert Museum One of the finest examples of the classic style with urn shaped nozzle with classic pilaster column, both urn and base decorated with festoons in classic style, of the period of I782, is a Sheffield silver candlestick. Sheffield was undoubtedly making fine silver candlesticks and candelabra at this period, and this is not unimportant in regard to the consideration of what she did as an echo of such work. During the last twenty years of the eighteenth century her output was 


\section{CHATS ON OLD SHEFFIELD PLATE}

of the highest character. Since I773, as we have shown, Sheffield had stood on her dignity as the proud possessor of an assay office with all the newly acquired rights of silversmiths jealous of infringements on so close a corporation. This had, without doubt, an enormous influence on the quality of the work perpetrated by the silver platers. Sheffield made a bid to become a silversmiths' centre and she has not lost her ancient ambitions to-day.

In the illustration given (p. 65) of a candlestick from a copper-plate engraving of pure Adam style, in date about I775, it is seen how far Sheffield had advanced to be able to send such pattern books with designs broadcast to buyers of her ware on the Continent of Europe. This and another illustration (p. 69) indicate the class of candlestick Sheffield was prepared to export. Sheffield had not snatched at renown, she had won it. A series of Design Books of the period, from which we reproduce illustrations, establish the fact that Sheffield plated wares were as acceptable on the Continent as being something especially English, as were the equally original products of Wedgwood in pottery, and at a later date the Ironstone Ware of Mason, where it is said that he inflicted more injury upon the French potters than did the English fleet under Nelson.

These are trade matters, but interesting withal, as they show the rapid rise under careful and 


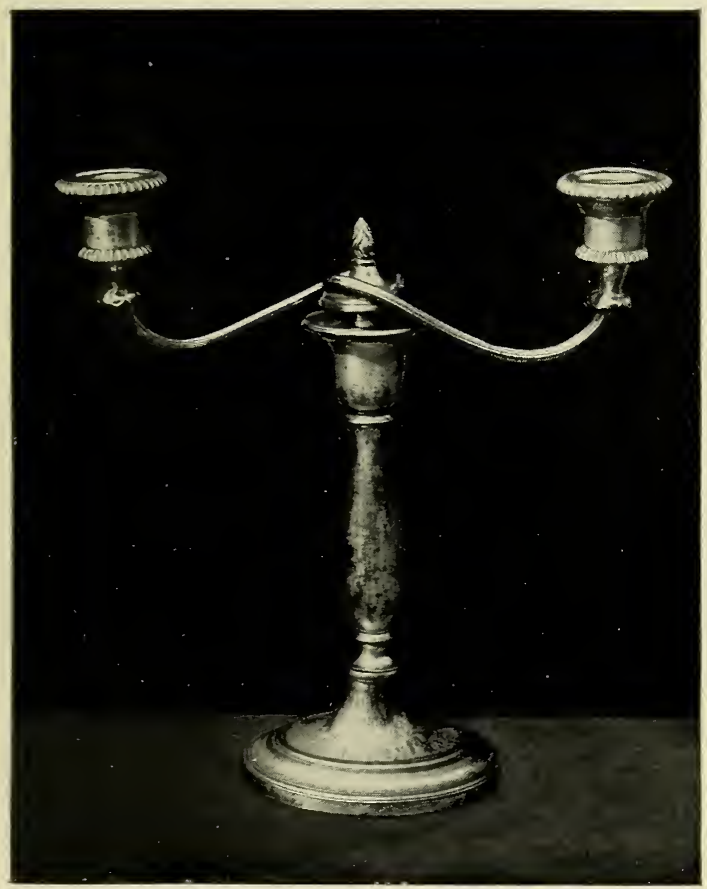

OLD SHEFFIELD PLATED CANDELABRUM.

With two lights detachable for use of standard as a single light. Removable notzles. Date about I800. Showing signs of copper owing to bad usage.

\section{(In the collection of Author.)}





\section{CANDELABRA AND CANDLESTICKS 89}

patient intuition of skilled craftsmen whose resplendent models tempted the Continent to buy our replicas where perhaps the original work was either not proffered for sale or was too expensive for the continental market.

We give another illustration (p. 75) of two table candlesticks, 1797 in date, sent out, as the catalogue states, by R. C. \& Co. (Robert Cadman and Company). In one example we have the favourite design of the ostrich feathers beloved of Hepplewhite and others in the chair backs of the same period. The classic influence of Adam is waning. There is nothing purely Grecian in the column. The Ionic pillar has long since disappeared. We have something as a substitute in design. The Maltese cross as a novelty finds itself as a feature in the design. It is composite, it is in a measure feeble in comparison with previous designs. It marks the oncoming period. It is just the sign of something confused in the design. We shall soon see something not only confused but extremely mixed and utterly banal with false and meretricious ornament, with little meaning except that here it stands, as ornament or as attempt at ornament, but as to balance or symmetrythat has been irretrievably lost. The age of decadence no one can explain. One marvels as much at ineptitude as at beauty in design.

Happily the Sheffield designers went backwards for some of their designs in a period that threatened decadence. The smaller of the candlesticks 


\section{CHATS ON OLD SHEFFIELD PLATE}

(illustrated, p. 75) suggests the reticence and simplicity of a brass candlestick of the Stuart period. As such it must be regarded. It stands quietly unassailable in its English dignity.

A fine clean-cut example, in date 1785 , of pure design, with facets sharply cut and decorated with ancanthus leaf design in due subjection, is illustrated (p. 83). The urn stem and the urn nozzle determine the period, and the candlestick stands on a fine round base. Its clear defined reticience is almost like cut steel work on a minor plane of the same period, such as frames to cameos and later adapted to purses and chatelaines. Cut steel mounts to clock faces belonged to the coming Empire days. Here, in this candlestick illustrated, is an indication of facetted work as clean cut as glass, which in its working and in its technique is a metal too.

The Candelabrum.-Whatever may have been the varieties of the hanging candelabrum in Dutch interiors, finely wrought brass and copper with a variety of designs always pleasing and so attractive as to find a ready duplication as a modern electric light candelabrum, we do not find the table candelabrum at an early date in England. As days went on it became massive, and had seven or eight lights. Old engravings depict Jewish and other candelabra as standing on the ground, sometimes of great height and with many lights, but for domestic use their acceptance as table or sideboard lights came in 


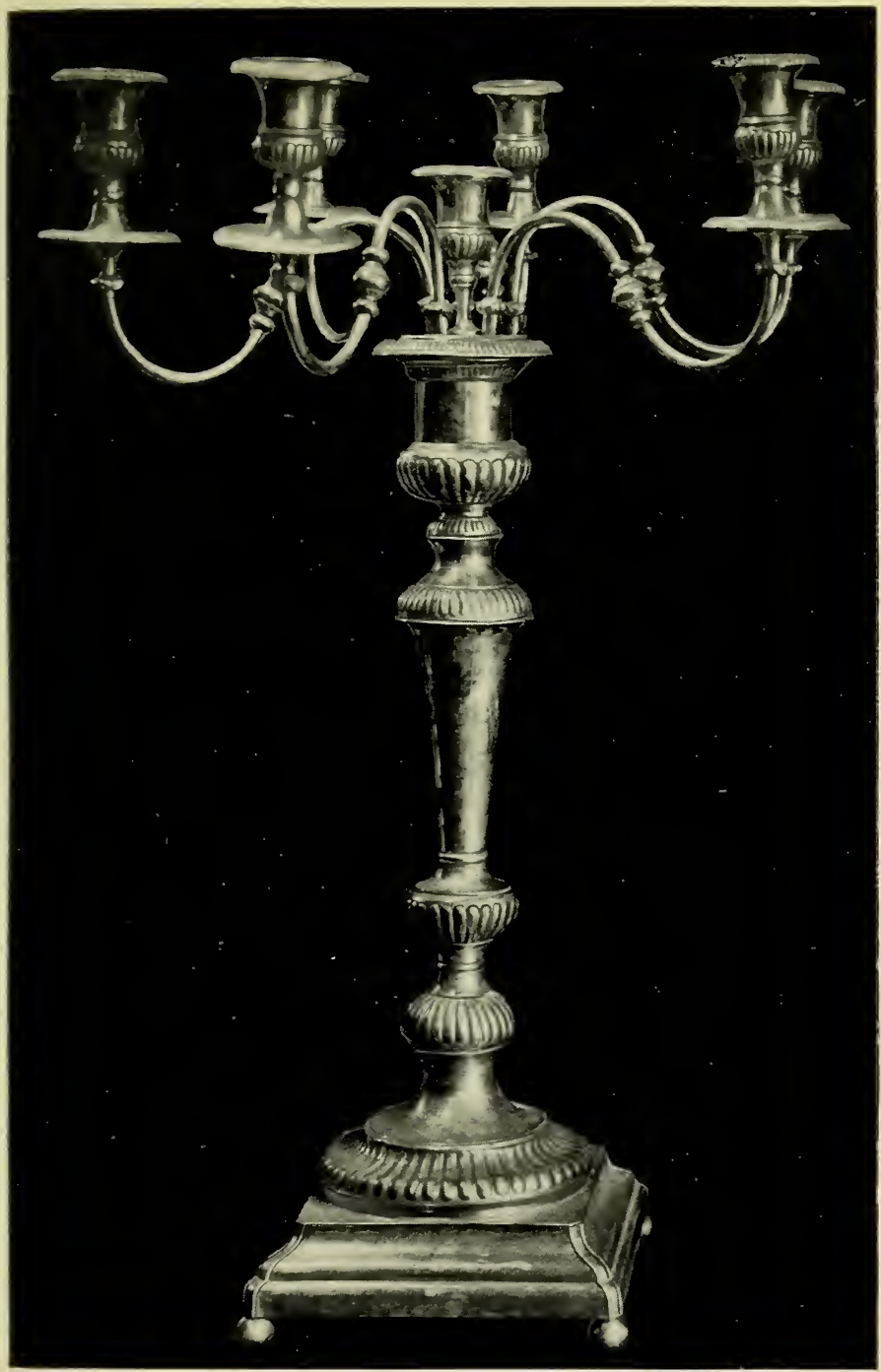

OLD SHEFFIELD PLATED CANDELABRUM.

Branched with seren lights. A square base with ball feet. Fluted decorations on column. Date 1820 .

(By courtesy of Walter $H$. Willson, Esq.) 



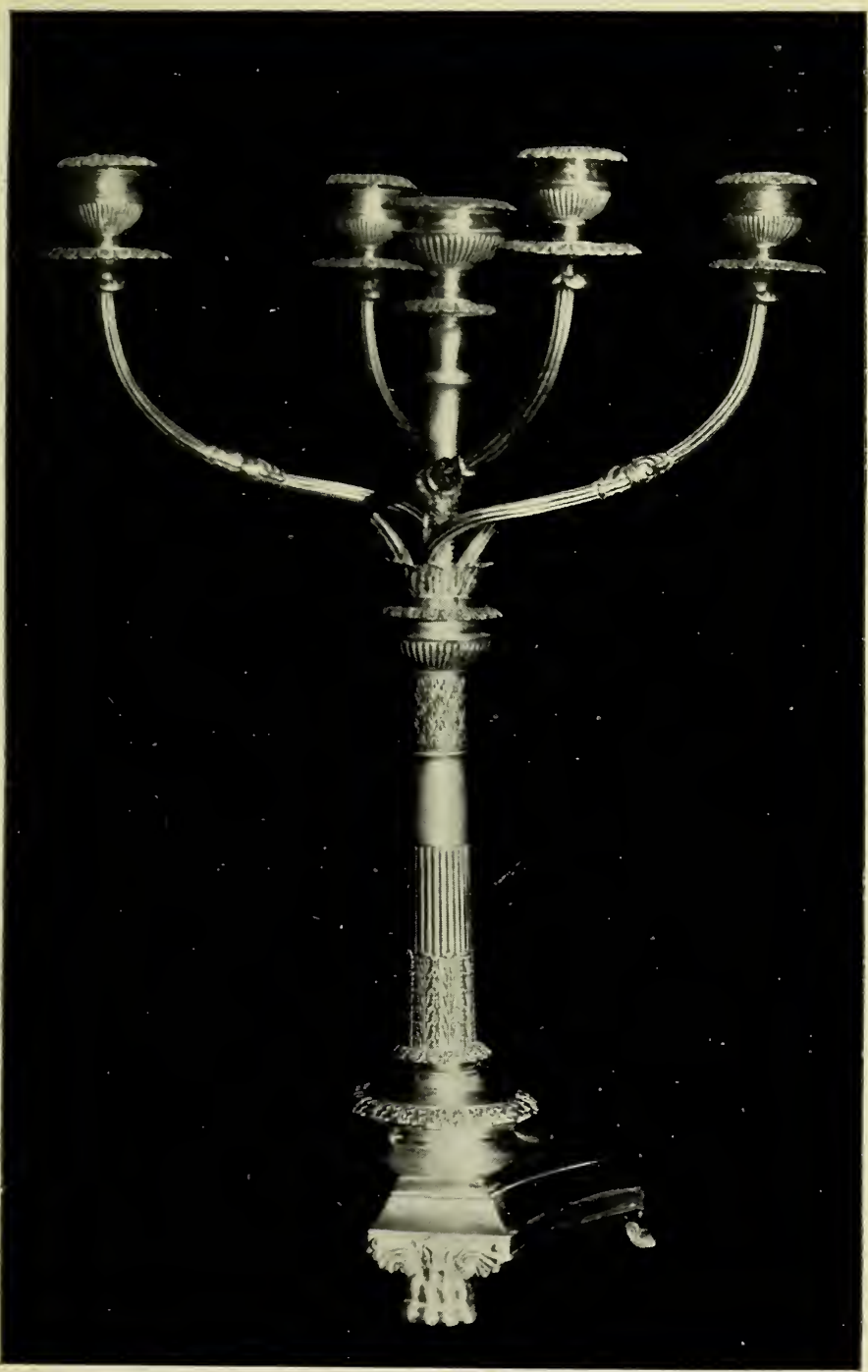

OLD SHEFFIELD PLATED CANDELABRUM.

With five lights: on hexagonal base with claw feet. Nozzles urn-shaped, richly decorated. Column with acanthus leaf and diaper ornamentation. Date I8Io.

(By courtesy of Walter H. Willson, Esq.) 



\section{CANDELABRA AND CANDLESTICKS 95}

the midddle eighteenth century, in Georgian days with great spread of mahogany and massive furniture. They seem almost related to the Adam resuscitation of classic candelabra on tripod feet. But most of the massive Sheffield plated examples bear relationship to Hogarthian preChippendale mahogany, and solid sideboards groaning with silver, engirt with monteiths and punch bowls and all the equipments of a period when members of Parliament hiccupped their speeches in the House, and when fox-hunting and portdrinking squires drank each other under the table. The evolution of the candelabrum from its simple form with two lights to its conclave of twelve is as interesting as the evolution of the gate-leg table during a somewhat longer period. In regard to practicability, as has been pointed out to the writer, some of the later replicas overdo the number in the attempt to be ornate, and if filled with candles and lighted they would burn each other. This is an interesting fact as indicating that sometimes in his attempt to be original the modern fabricator invents something that could never have been used. For, after all, our ancestors, however handicapped they were by want of illuminative mechanism, were never so foolish as to employ candelabra that would cause guttering by one candle firing another on account of its close proximity.

In considering candelabra, the ordinary branched three-light candelabrum is interesting, and many 


\section{CHATS ON OLD SHEFFIELD PLATE}

forms follow each other indicating the steady progress onwards. The example illustrated (p. 87) is capable of being used as a single candle or as two lights. It is in the usual nomenclature of the trade termed a three-light candelabrum, though only two lights are capable of being used at the same time. The nozzles are removable. Now the removable nozzle was not introduced into silver plate until about I758, when the tall Corinthian column types first had this invention. But the example under notice has other indications to place it about I80o. It has the slight sug. gestions of oncoming Empire style, the commencement of a return to austerity, a poverty of design, and the urns and nozzles betray the newer forms of ornament. The oval bases and the touch of floriate ornament under the nozzle urns have their indicative note. It will be observed that the camera, with more penetration than the human eye, has brought out the thinness of the plate, and it is here represented in the illustration. It denotes perhaps less of a delinquency on the part of the plater or a flaw in his technique than a grave indictment against generations of housemaids who have used metal polish which contained mercury or some other noxious compound inimical to the longevity of the superimposed silver. So here it is indicating a last stage of its simulation and the base copper peeps forth triumphantly.

A glorious candelabrum of massive form branched 


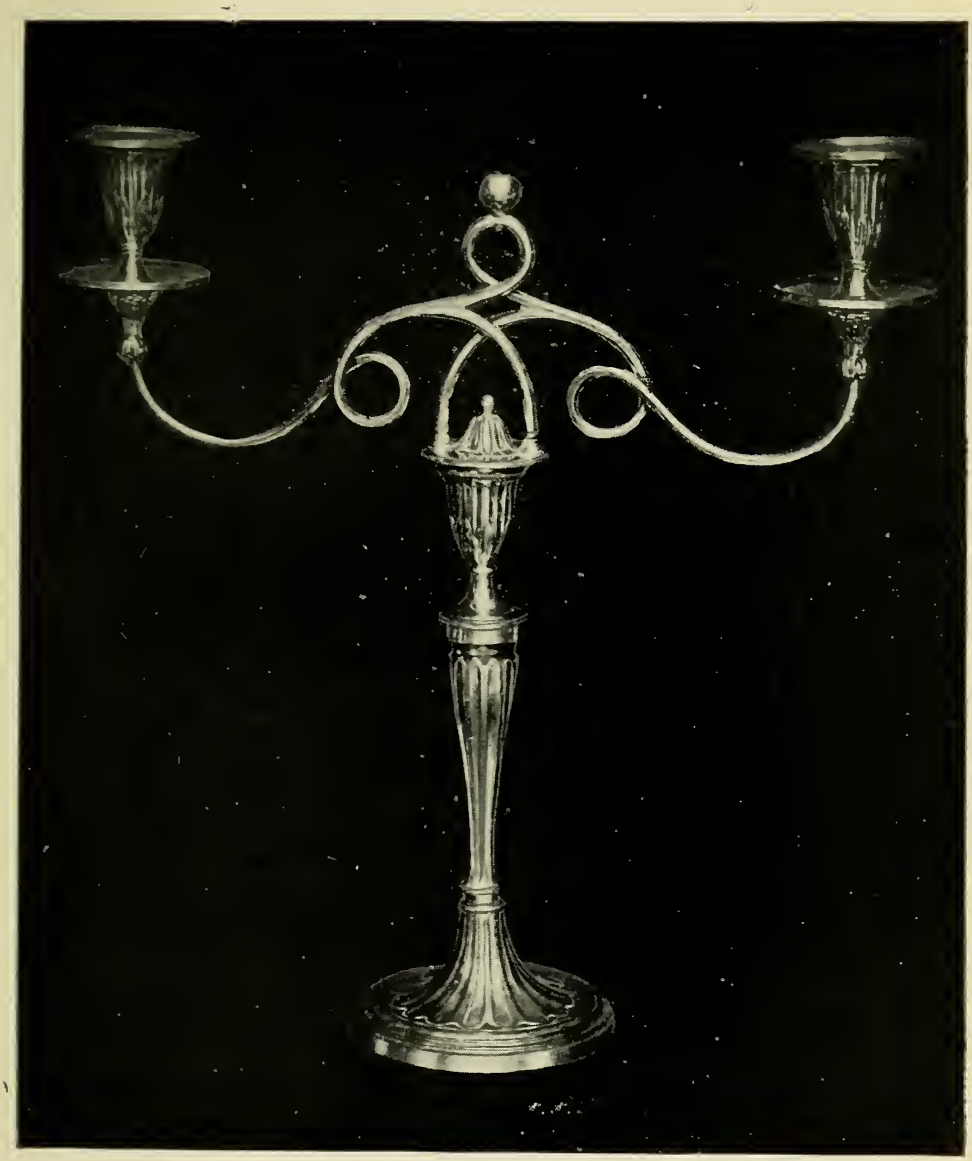

OLD SHEFFIELD PLATED CANDELABRUM.

One of a pair. Two-light : about I790. Fluted column handwork. Fluted leaf ornament on cups, with Gothic looped branches surmounted by an acorn.

(In the collection of B. B. Harrison, Esq.) 

with seven lights on square base with ball feet is in date about I820 (illustrated, p. 9I). The grease cups indicate its late date, and underneath is the same bud-like floriate ornament we noticed in the last example. But in addition to give it yet a later date is the broken branch with balllike ornament. It is a fine example, especially noteworthy as being representative of a period just before a decadence of design set in which thrusts the collector out and freezes any interest he may take in perfect technique by reason of a fearfulness he has of banal design.

A splendid example of a candelabram with five lights, one of a pair is illustrated (p. 93). The late classic influence from Pompeii derivative through French sources is here evident. The tripod stand terminates on claw feet embellished by a floriated winged design. The column has a richness almost akin to the worker in ormulu. The base is decorated with ancanthus leaf ornament, followed by ordinary fluting which breaks off in the centre of the pillar. The upper portion is decorated in a diaper pattern and the capital is a fluted urn, from which spring the branches. The grease pans are richly godrooned, and here the feature underneath is noticeable, the little circular boss beneath the pans. At a later date the grease pan disappeared, but the little rosette was left. This is especially noticeable in the example in date I800 (illustrated, p. 87). The grease pans have become too diminutive to be 


\section{CHATS ON OLD SHEFFIELD PLATE}

of use, but there is sufficient suggestion of their presence left to disturb the fine proportions of the urn above. The fluted branches have an added ornament which it is charitable to believe was placed there for practical reasons to give added strength to the branches, but denotes a wavering in design from exquisite, unbroken curves. Ornate as this great candelabrum is, possessing design carried out with cunning technique, there are restless elements in its conception, which mark it as belonging to a transition period.

The Varieties of the Spiral Form.-There is something peculiarly interesting in following the variation of spiral forms in the branched candelabra from the early days until at the last they sank into mediocrity and became in the last stages little better than what was afterwards the standard pattern of the mid-Victorian gas bracket or gas chandelier, with its meaningless branched arms and its fulsomeness of meretricious ornament, a form, be it said, actually copied by the early electricians till they learned better and walked serenely in the paths of old design.

It would appear that at first the spiral curl of the branched candelabrum was in due subjection, that is to say, it was a well considered part of a complete design. It fell within the four corners of a set harmonious whole. It did not detract from the whole by any eccentricity, nor did it attract especial attention except as 


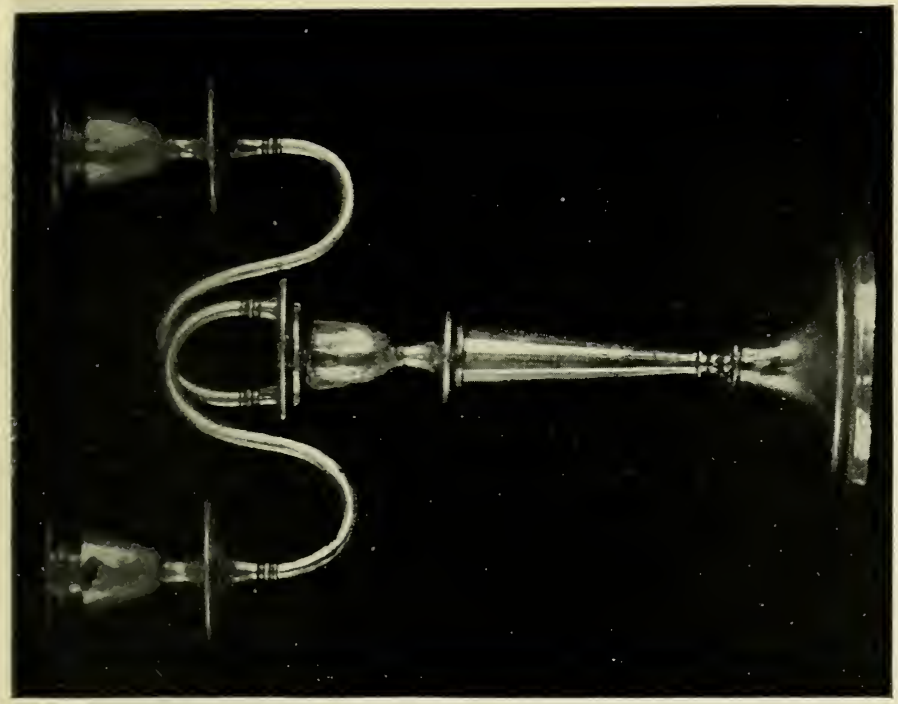

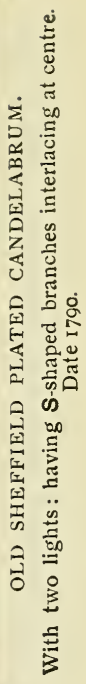

$\vdots$
$\vdots$
$\vdots$
$\vdots$
$\vdots$
$\vdots$
$\vdots$

ป

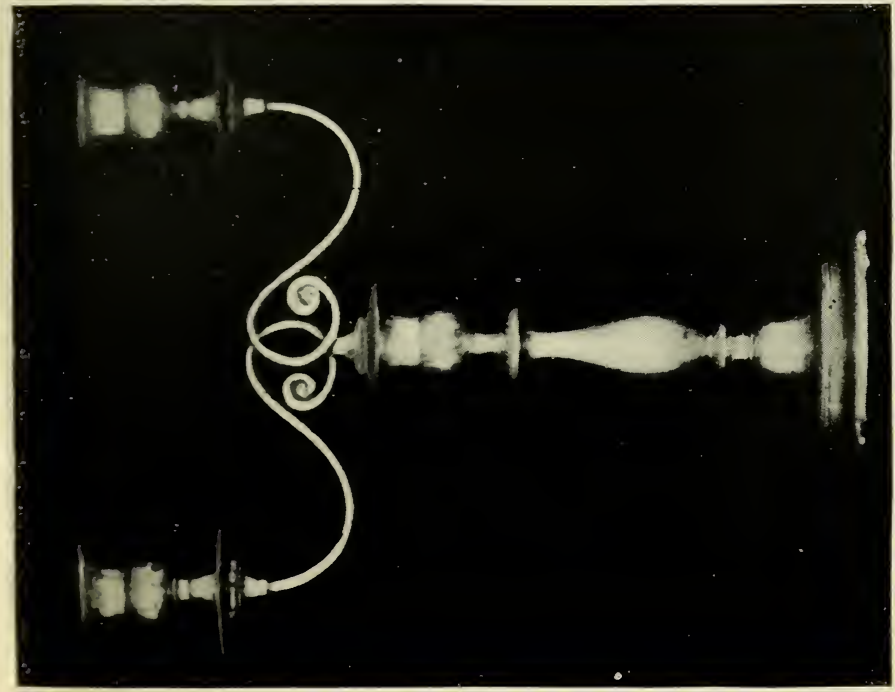

당

जू

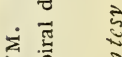

के के

"ृ

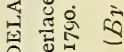

艺志嵌

ठิ $\Xi 气 ็$

D 3

(됨

듕

征洁

은

国至

(马)

(s)

$\ddot{g}$ 品

o

a $=$

○

吾 



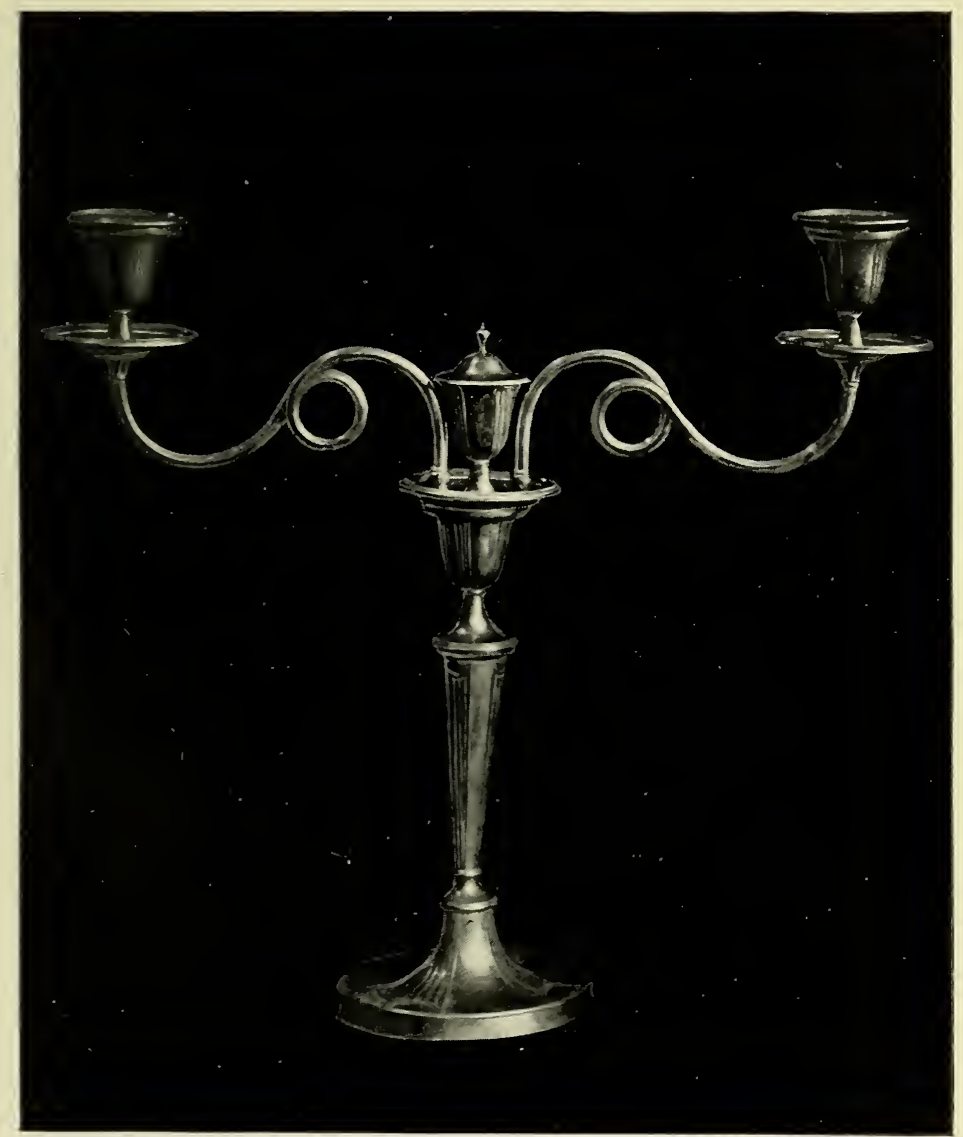

OLD SHEFFIELD PLATE CANDELABRUM.

Two lights, oval base, removable nozzles, fluted lobes, and single spiral branches. Date 1790.

(By courtesy of Walter H. Willson, Esq.) 

a factor in an ensemble. For instance, take three examples and exanine them minutely. The first is on one of a pair, in date I790 (illustrated, p. 97). The convolutions of the spirals are apparently intricate till one more closely realizes that they approximate to the Gothic designs then being promulgated by Chippendale. The top loop forming a circle, the side loops forming similar circles, the intersections of these and the lower arcs forming an angle over the urn-ornamented nozzle are little other than the loops and angles forming the tracery of a Gothic design which might with little addition be the leadwork of a window. These same designs may, with an observant eye, be traced in fanlights and doorways in the suburbs of London where the middle and late eighteenth century styles still linger in the façades and in the railings.

Take another example still in date about I790 (illustrated, p. ror); here the base is an urn and the single-candle standard form nothing very especially removed from a design very beloved by the brass turners of a slightly later date. But it is the branched form which commands respect as a piece of decorative ornament. Its C-shape spirals interlace at centre and form a pleasing ornament. Its simplicity and grace are at once apparent. It has the practicability that it is not readily injured by ill-usage. Its wearing parts are confined to a narrow space. Among all the spiral forms there is nothing, however 


\section{CHATS ON OLD SHEFFIELD PLATE}

elaborate, that excels this in grace. It is almost honeysuckle like in conventional ornament. We have seen the ironworker spin such reticent spirals, but in the silversmiths' work it is rare to find this form.

Another I790 design (illustrated, p. Ior) carries the loops out in such a manner as to suggest an elongated urn. The oviform intersection of the loops, plain and formal though they appear at first glance, do not come into such a severe classic position by mere accident. The low dropping loops afford just that contrast and upward spring which make the intersection, and give it its maximum ornament as two bands enclosing a space, which space is in itself a component part of the ornament to the candelabrum.

Two fine examples illustrated (pp. I03, I07) exhibit respectively the fine use of the twisted form in the arms. They are both two-light candelabra with central vase ornament. In the former with single loops the vase is very properly left nearly level with the apex of the arms. This would have been a blemish in the other example illustrated (p. I07), where the vase ornament is larger and carries off the strong double twisted design in the arms. This example is original in its treatment of curves and carries the idea to the utmost limit. Beyond this the ornament became disastrous and added a note of eccentricity to otherwise well-balanced designs.

When the loop went awry, as it did, it became 


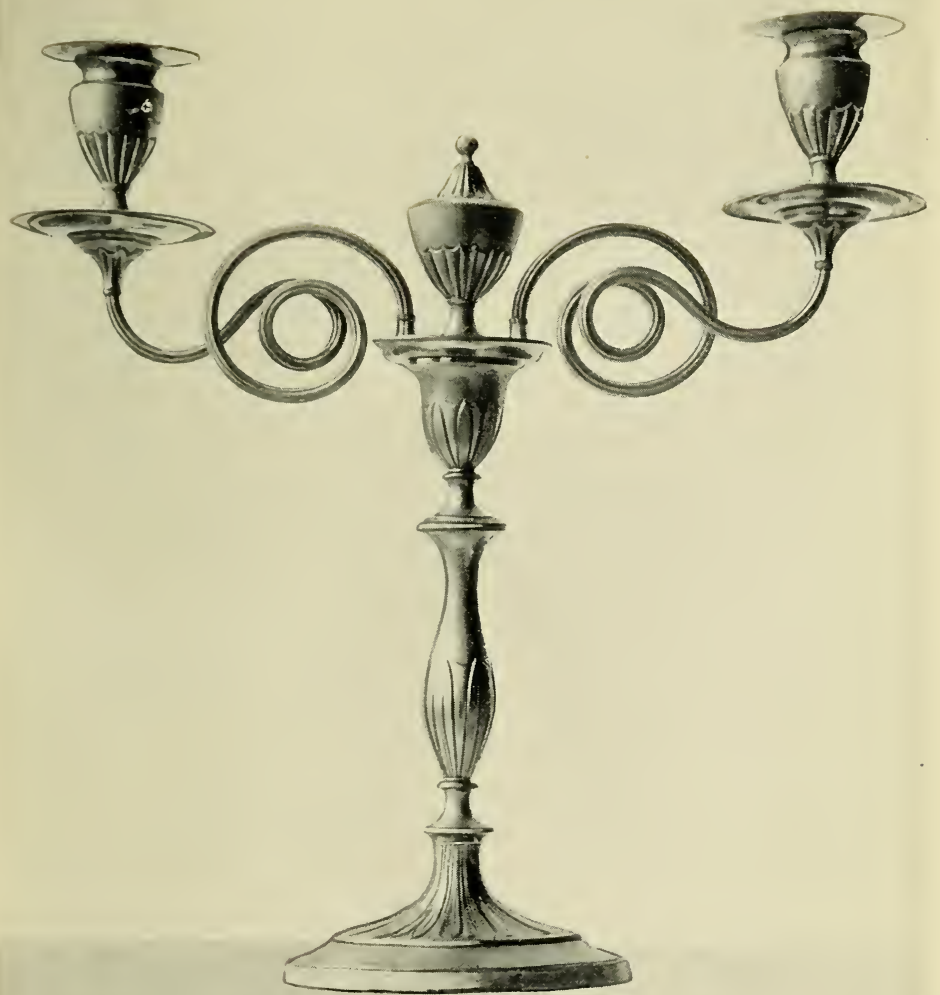

\section{OLD SHEFFIELD CANDELABRUM.}

Two lights: oval base, acanthus leaf decoration in column. Double spiral branches.

(In the collection of B. B. Harrison, Esq.) 



\section{CANDELABRA AND CANDLESTICKS 109}

an excrescence. In two examples this is shown in varying stages of decadence. It is obvious that the designer had lost sight of the fact that the curved loops could so be manipulated as to become an integral part of the design and contribute to its harmony. The same thing happens in regard to chair-backs. It was here that Chippendale proved himself a prince of designers. It was not so much what he put in as what he left out. In other words, take a great design of one of his superlative chair-backs and let the eye trace the spaces, that is the space form, trying if possible to eliminate the concrete solid design. The silhouette of the outlines of the spaces are really the key to the justness and beauty of the design. If one could remove the mahogany portions of an intricate carved back and placing it against a black sheet retain the beautiful outline of the spaces, the result, example after example, would be a design book in itself as fascinating as a book of Japanese stencil plates.

In the example I795, with the three lights (illustrated, p. III) there is little to quarrel with the design except that the long stem and wanton simplicity and lack of grace suggest the cast iron standard which effect is carried out by the common place spiral leading to the central light, which, by reason of its curves, attracts an attention to itself which is unwarranted by any special beauty it possesses. It is a blemish. It has no 


\section{CHATS ON OLD SHEFFIELD PLATE}

meaning as a curve and it detracts from a simplicity which otherwise the candelabrum might possess.

The other example illustrated (p. III) has unmeaning spiral design utterly vitiating an otherwise harmless candelabrum. Its spirals run riot and offer nothing pleasing. They stand as an attempt undoubtedly original on the part of the designer to produce something effective as a novel design. The style otherwise of the candlestick does not suggest that the craftsman had a hold upon sound design, but we might pass that. We are extremely thankful to know that nobody seems to have continued this style. In all possibility, by the laws of practical usage, the housemaid placed her vengeance on the offending spiral arms with no support and they broke in halves. The same servitor teaches the offending potter a lesson when, in vessels intended for everyday use, he adds ornament that is unduly projecting in handle or in spout. They pass into the heap of shards because common utility abhors useless ornament.

As a comparison with other forms of branched candelabra and as exemplifying the completed mastery the artist craftsman had over his design and its execution, two examples of rare form and character are illustrated (p. II3). The twolight candelabrum is of unusual shape, the standard being a full-bodied urn on which stands another urn. Branches issue from the lower urn 

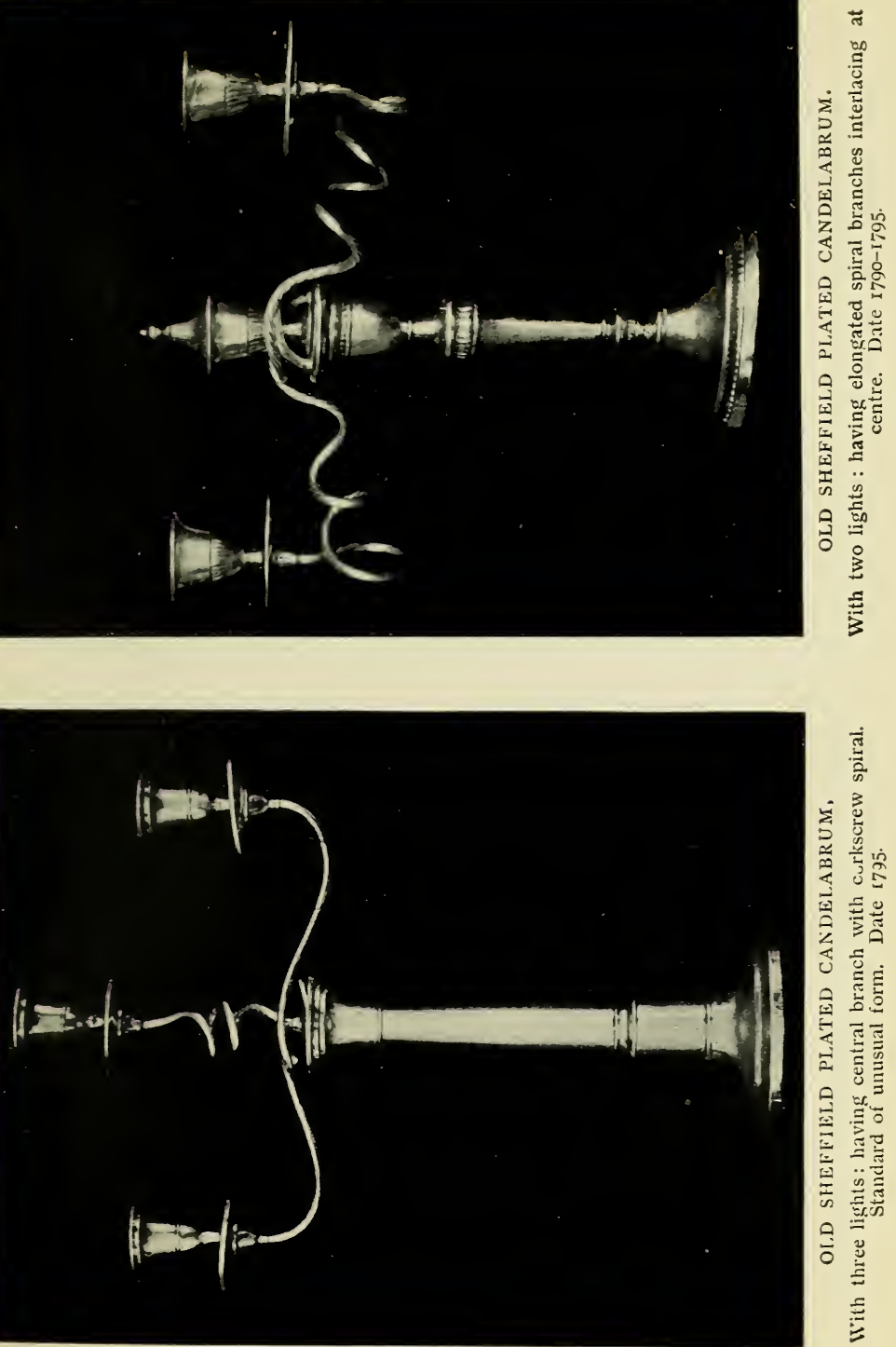



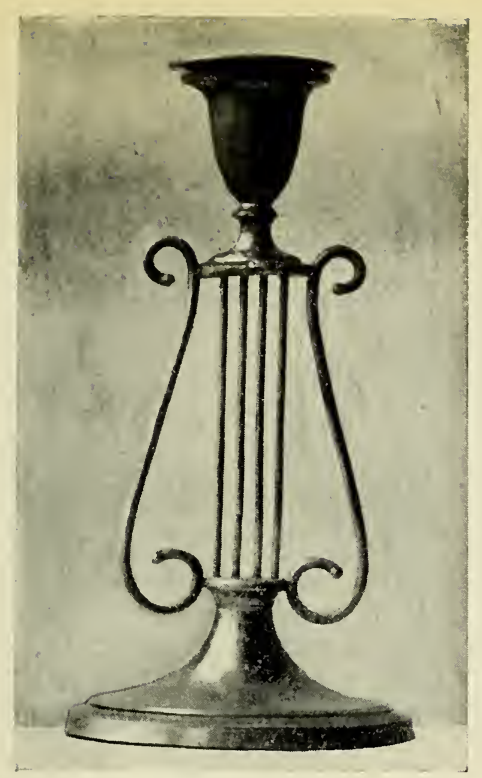

OLD SHEFFIELD PLATED CANDLESTICK.

Un oval base, with standard in form of lyre. Threaded oval cups and nozzles. Date 1795 . Height Io in.

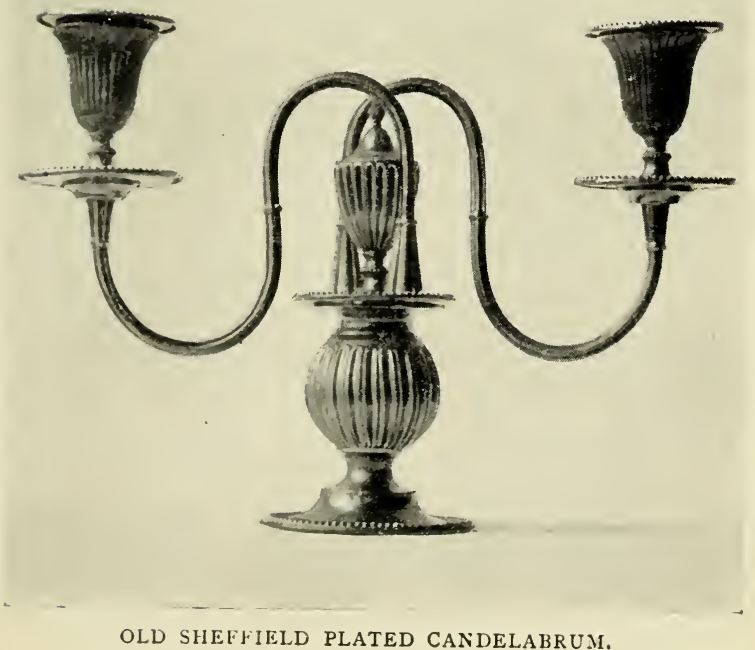

Will two lights : having S-shaped branches, with standard in for $\mathrm{m}$ of vase surn:ounted by another vase ornament.

(In the collection of B. B. Harrison, Esq.) 



\section{CANDELABRA AND CANDLESTICKS 115}

and in their intersections form beautiful curves of pleasing form.

The single candlestick (illustrated, p. II3), has another adaptation of curves in ornament. The standard springs from a circular base and is in the form of a lyre which supports an urn-shaped nozzle. This form undoubtedly is derivative from French sources. We find it in ornaments to metal clock cases, and it bespeaks the Sheraton period in possessing a grace and finesse associated with the designs of Louis Seize that he acclimatized in this country.

The Tri-Form Candelabrum.-The candelabrum with three branches has been found capable of much variation in character. These branches have had the advantage of being able to conform to conventional usages in regard to a triangular conformation and a trifid ornament. It is a favourite device in art from the lotus leaf of the Buddhist emblems to the fleur-de-lys. The love of a threefold ornament appealed to the woodcarver, and it is found on sprigs decorating porcelain. The use of three balancing adjuncts in ornament is universal, apart from the deeper or symbolical meaning of such forms.

In the example illustrated (p. II 7 ), in date [805, the three curved branches spring upwards and the lights are all level. This form is typical of some of the best three-branched candelabra then made. It is solid and massive, and has no false or overloaded ornament. It is dignified 


\section{CHATS ON OLD SHEFFIELD PLATE}

and imposing. The other example, in date I8Io, illustrated on the same page, betrays at once classic influence. The old models of Herculaneum and Pompeii had been eagerly refashioned as something new in the First French Empire. The portrait of Madame Rècamier by David shows her sitting on an empire settee with a tall standing candelabrum at its foot. The couch is a replica of old Roman stone forms and the candelabrum is a duplicate of a Pompeian style on tripod feet. The candelabrum illustrated has a stand consisting of three tapering legs reeded, and ending in claw feet. This supports an urn which in its turn supports another, which latter can be used as a light. From the lower urn proceed three branches, spread out in triangular manner.

A later candelabrum with two arms and centre light, illustrated (p. I2I) betrays every sign of bad design. The floral scroll work is hard and offensive. The leaf and shell ornament at base is equally unsatisfactory. It was this form that survived as it came on the threshold of the era of illumination by coal-gas. It was about this date that Sir Walter Scott lit Abbotsford by gas. "His application of gaslight to the interior of a dwelling house was in fact attended by so many inconveniences," says Lockhart his biographer, " that ere long all his family heartily wished it had never been thought of. The effect of the apparatus was at first superb. In sitting down to table in autumn no one observed that in each of three 

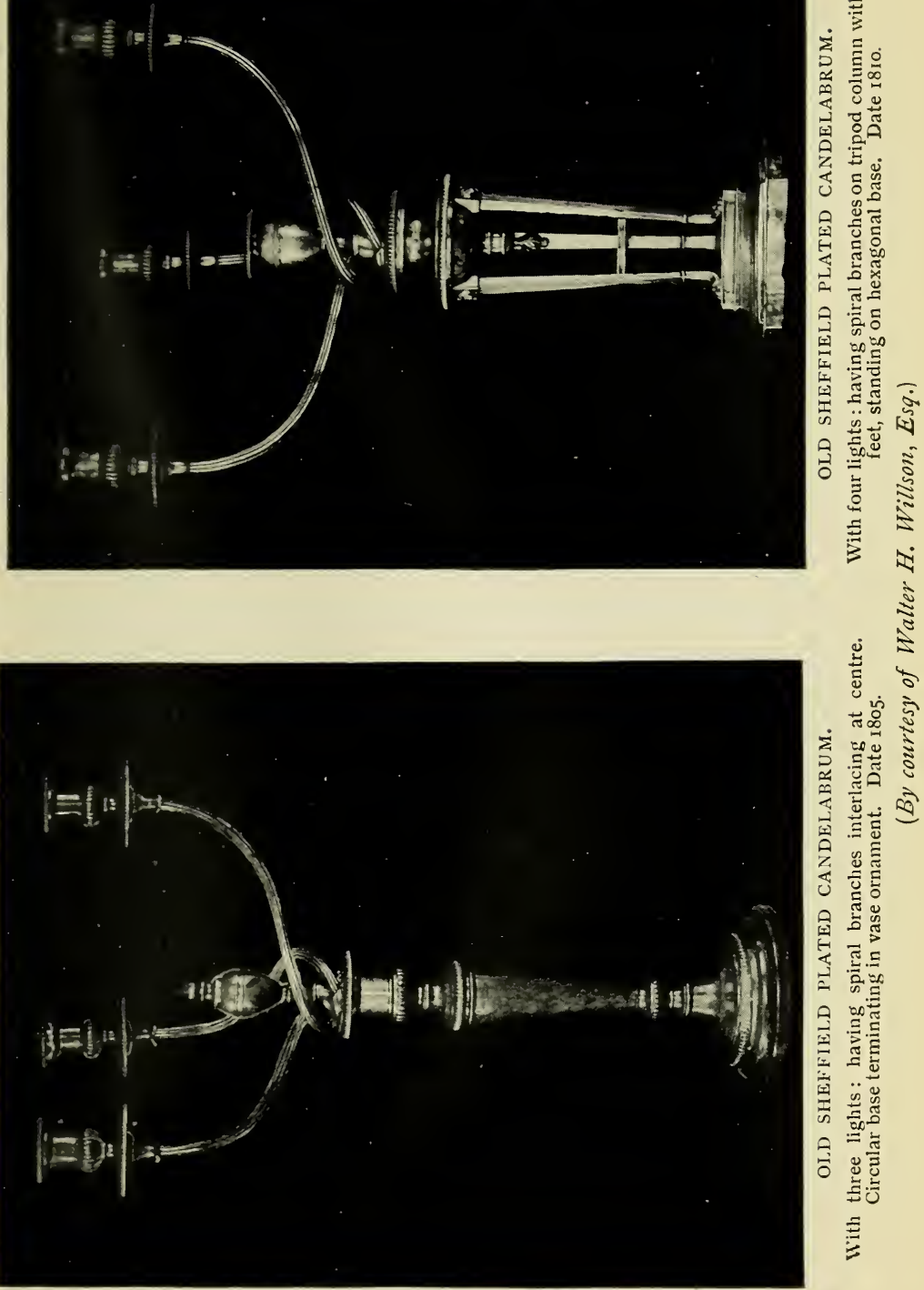



\section{CANDELABRA AND CANDLESTICKS 119}

chandeliers there lurked a tiny bead of red light. Dinner passed off, and the sun went down, and suddenly at the turning of a screw, the room was filled with a gush of splendour worthy of the palace of Aladdin; but as in the case of Aladdin, the old lamp would have been better in the upshot. Jewelry sparkled, but cheeks and lips looked cold and wan in this fierce illumination; and the eye was wearied and the brow ached if the sitting was at all protracted. I confess, however, that my chief enmity to the whole affair," continues Lockhart, arises from my conviction that Sir Walter's own health was damaged in his latter years in consequence of his habitually working at night under the intense and burning glare of a broad star of gas."

The Chamber Candlestick. - This form has had a long survival and up to quite a recent date, before the adoption of electricity, a row of earthenware candlesticks formed part of the appurtenances of the hall or corridor of any provincial hotel. The illustration (p. I23) entitled Serena, from an engraving by J. R. Smith after Romney's picture, shows a fair reader, entranced in some old world romance, illuminated by the light of a single candle, as injurious in its faint glimmer as was the glare of the gas to Sir Walter Scott. Romney painted Miss Sneyd as Serena at a date between I770 and I790. The form of the candlestick in the print, it will be seen, differs somewhat from the Sheffield plate examples illustrated on 


\section{CHATS ON OLD SHEFFIELD PLATE}

the same page. The example with the circular nozzle and circular base is in date about I8Io, and the two others with square nozzles and square bases are in date respectively $18 \mathrm{I}_{5}$ and I825. They are ornate in their ornament, and have silver filled mounts and edges. The example of the latest date is silver gilt.

\section{The Evolution of the Table Candlestick.-} The table candlestick is of long lineage. The Sheffield plated examples cover the last hundred years of the existence of the candlestick as a means of domestic lighting. During this period, especially during that portion from I765 to I790 a brilliant procession of fine designs in silver, made under the direction of highly inspired artistcraftsmen, exhibits a flexibility of ornament and a diversity of character rarely equalled in English metal work covering so short a period of time. It embraces the traditions of the Queen Anne period still retained in the types carried on in the reign of George II as robust as were the designs in mahogany in Chippendale's early manner following the broader splats and swelling lines of the Hogarthian period. With the Adam influence reticent decoration eminently fitted to grace and embellish table ornament made its permanent impression on the period, tinctured with inclinations towards flowing lines-the ribbon decorations of the carved wood chair-back, or later the subtle graces of boudoir art reflected in the designs of Thomas Sheraton. And with the steady 


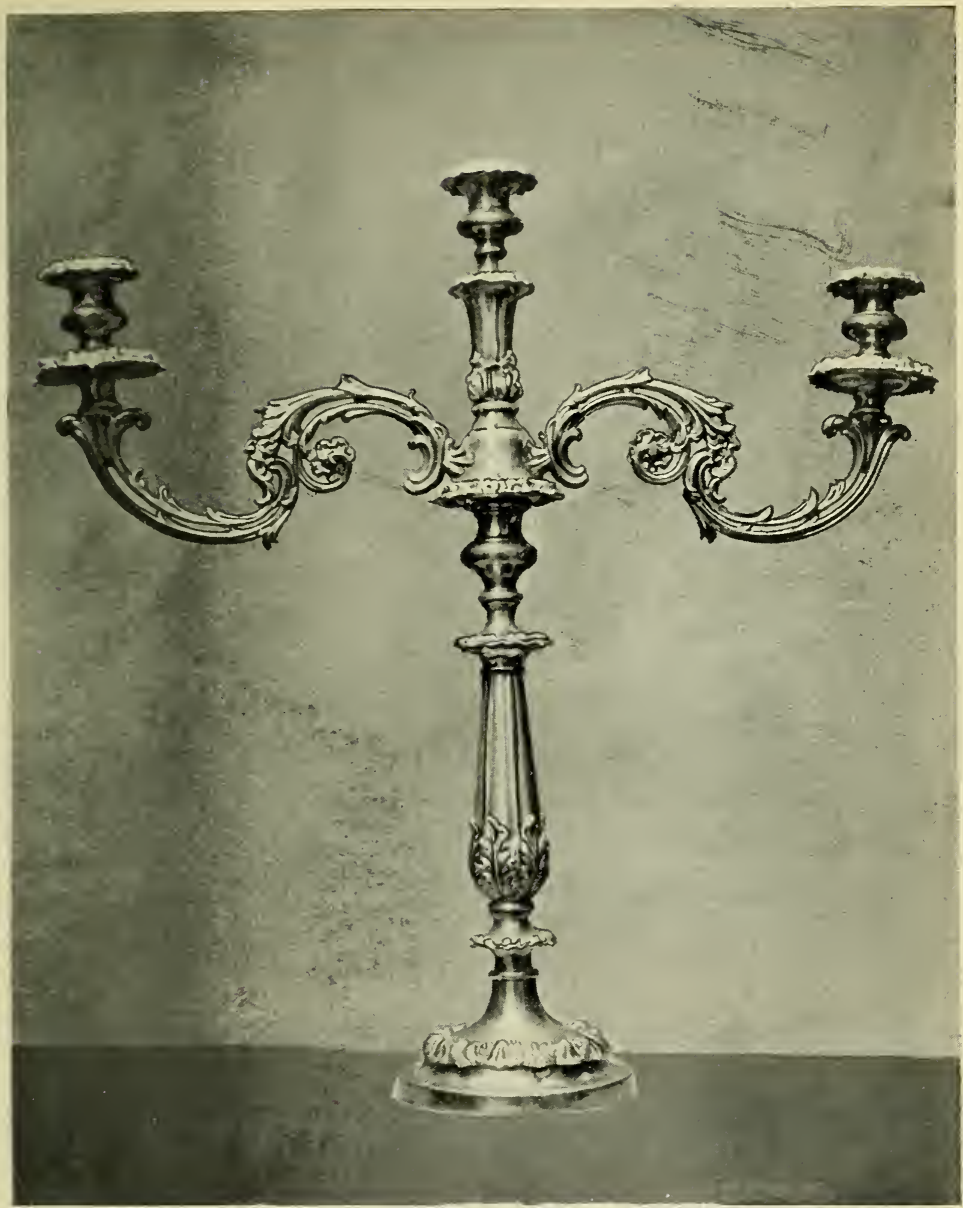

OLD SHEFFIELD PLATED CANDEI,ABRUM.

With two aıms and centre light. Arms curved and ornamented with floral scroll work. Base p'ain, with circular band of silver leaf and shell ornament. Height 24 in. Width $2+$ in. Date 1820 .

\section{(At the Sheffield Public Museum.)}

(Reproduced by permission of the Corporation of Sheffeld.) 



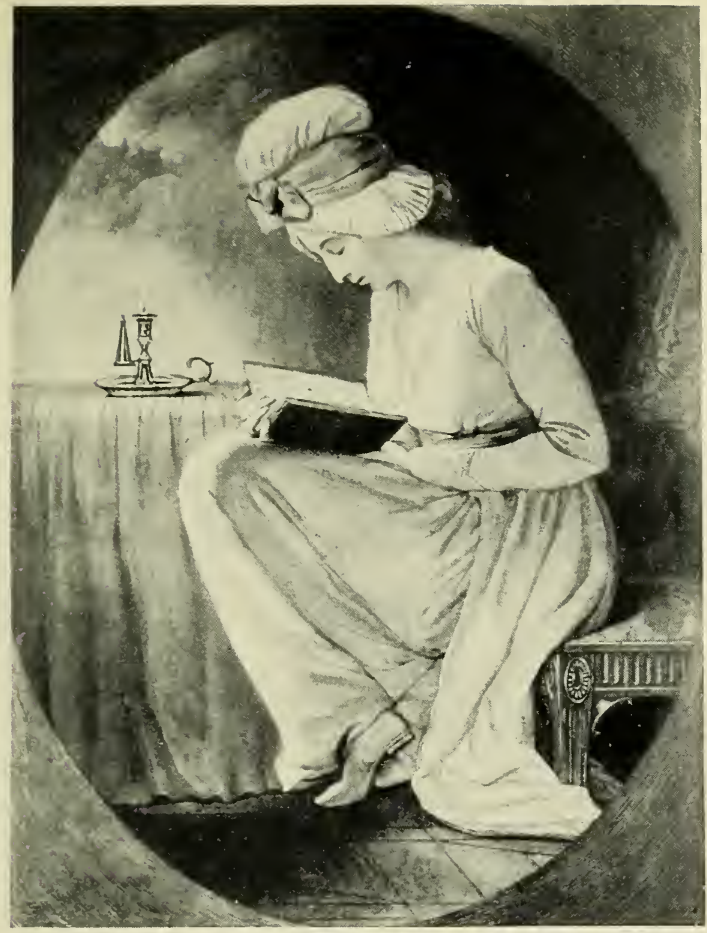

"SERENA."

(From an old print.)

Engraved by J. R. Smith, after Romney.
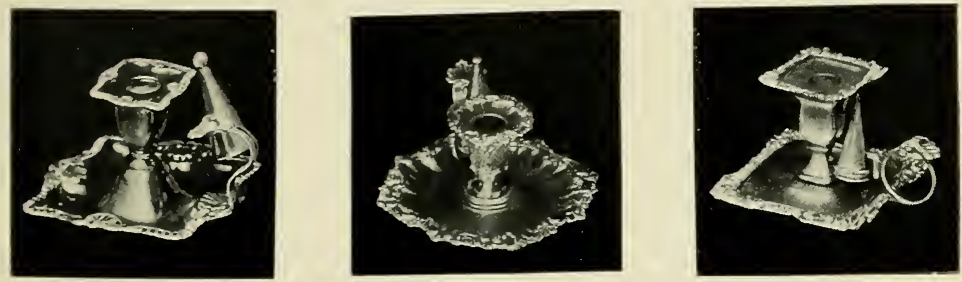

OLD SHEFFIELD PLATED CHAMBER CANDLESTICKS.

Gilt : silver-filled, gadroon and shell edges. Date 1825 .
Circular base, vase-shaped nozzle, silver-filled mounts. Date 18 Io.
Square base, ornate silverfilled mounts; single plate. Date 18i5. 

flow of models of table candlesticks reflecting the exuberance and native originality of a crowded art-period the creations of the potters were running concurrently in emulation of silver. Chelsea and Bow produced candlesticks environed with peasant maids and shepherdesses, in the technique appertaining to the clay, rich in colours and pleasing in effect. Wedgwood produced table candlesticks in black and blue jasper ware with cameo decorations in white, or finely modelled classic figures in basalt in which candelabra were embodied, and running through the period are the competitive creations of table candlesticks as an echo of silver forms by the glassworker.

The series of illustrations of the various types of Sheffield plated table candlesticks do little more than approximately indicate the rapidly changing styles in a period so richly inventive in decorative ornament. In the group illustrated (p. I27) the example on the left, in date I765, is on a square base with cluster columns and leaf capitals. The example on the right is in date I770. The base is round. It is here that the plater has exercised his ingenuity in fine reticent die work, and the edging is delicately beaded. The candlestick in the centre has a square base, with fine batswing fluting, and squareshaped columns ornamented with classic medallions. The nozzle has a character of its own in having a rim which is pierced.

The illustrations (p. I29) show other forms 


\section{CHATS ON OLD SHEFFIELD PLATE}

in process of evolution. The tall Corinthian column made a handsome table ornament. The example on left is one of a set of four, twelve and a half inches high. The bases are square and are decorated in clever die work with rosettes and festoons carried around the pyramidal base. This type has cluster columns terminating in capitals decorated with formal leaf design. The adjacent candlestick is a form found about I790. The base is square and fluted, and the column is in classic style terminating in a capital in Ionic style, with volutes springing out of twisted leaves and husks. The third example in the upper row is about I795 in date. The base is square and follows the same classic suggestions of previous types. The capital is square and fluted, and is decorated with conventional floral ornament. The nozzle is urn shaped.

The three lower examples of the period from I8Io to I830 show signs of debasement in form. The bases have now become circular. Each candlestick has certain beauties in it, little touches which invite respect and regard, but each also contains blemishes detracting from the exact symmetry which was the character of the earlier types. The floriate decoration as an ornament to the lower half of the column in the first example may be passed. In the second it has grown into an unpleasing excrescence, and the base is decorated in a florid manner disturbing to the eye. The last example has lost that fine feeling dependent 

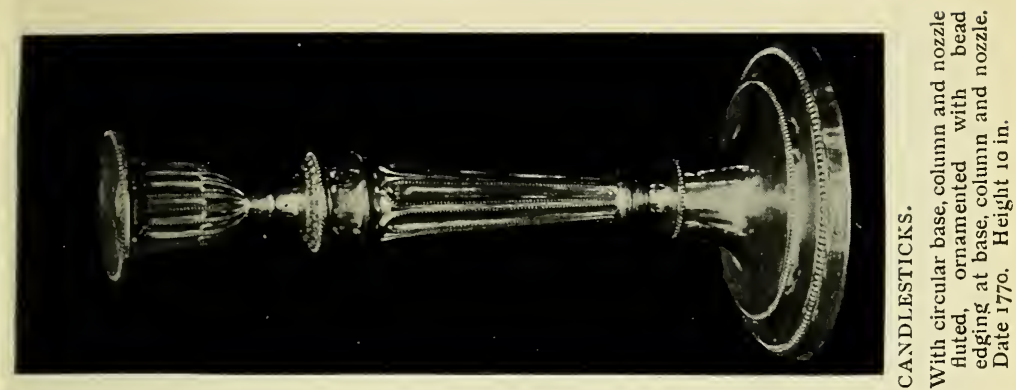

氠
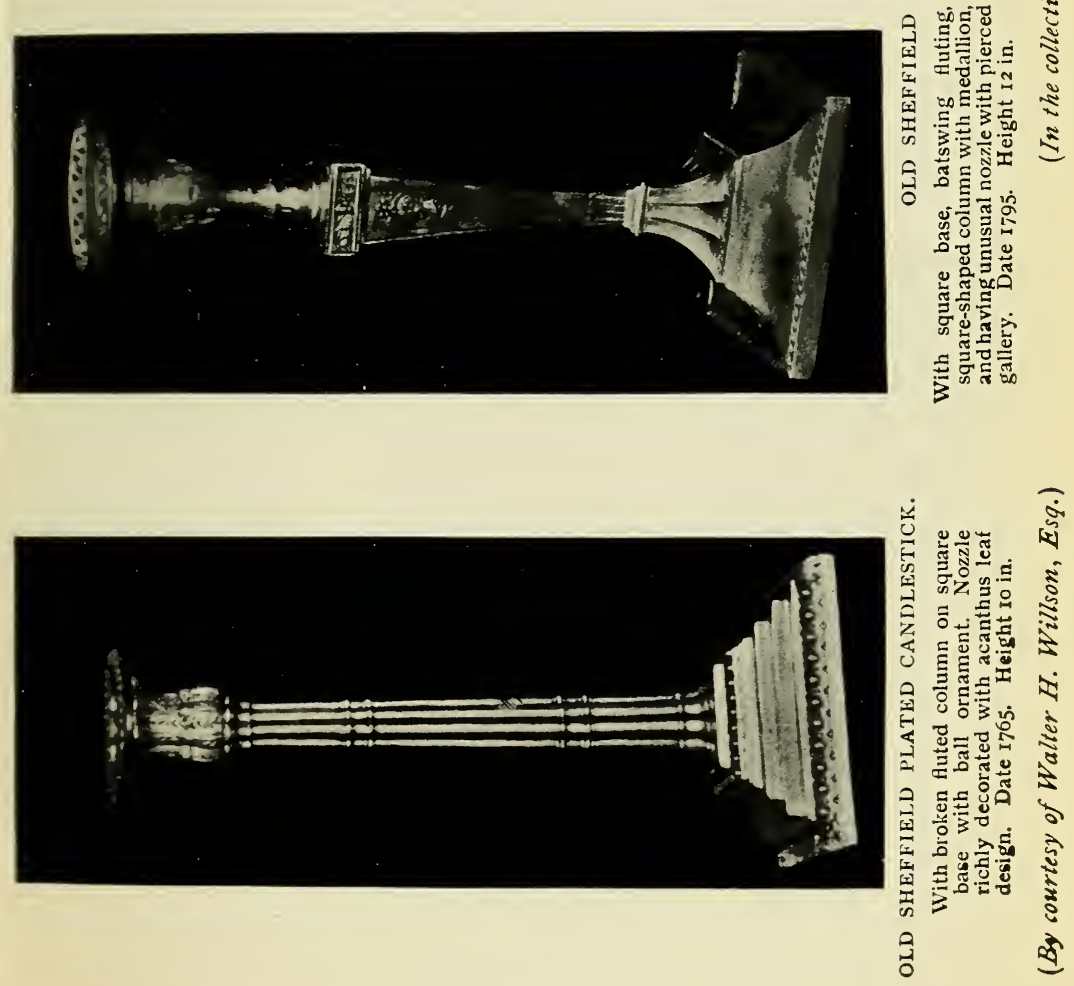


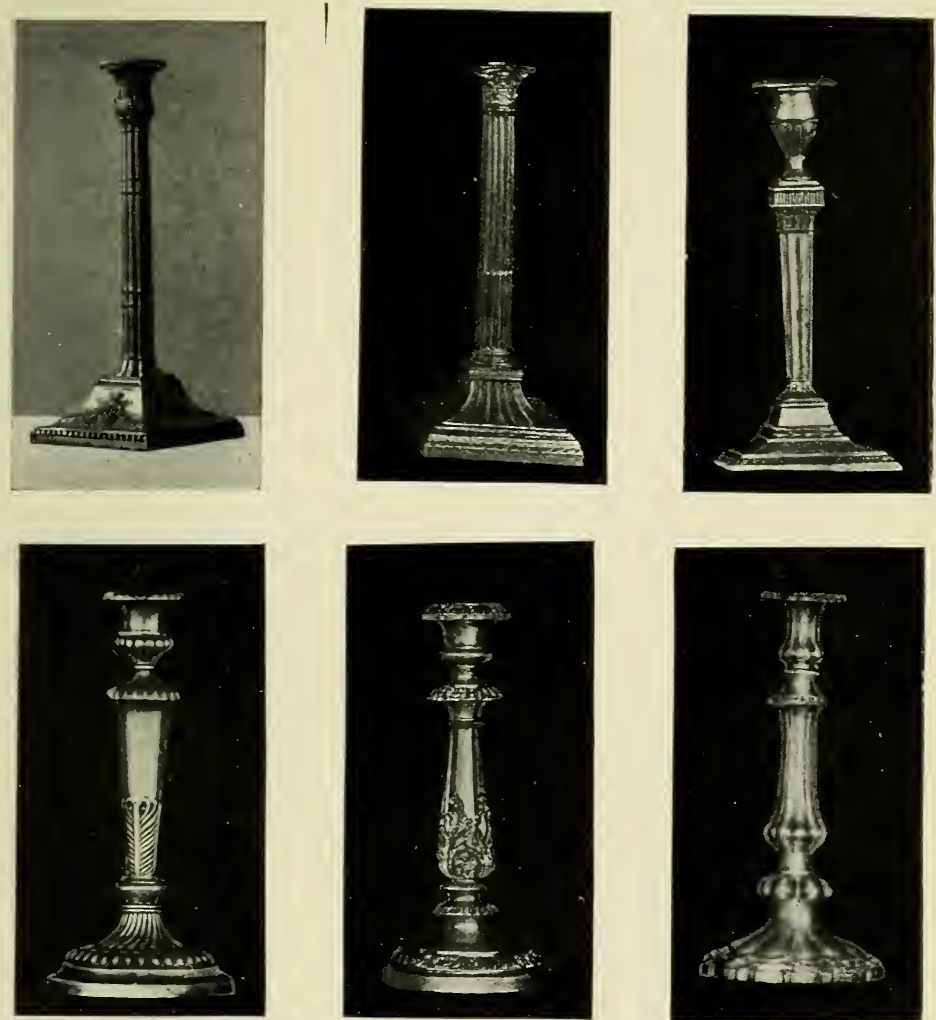

GROUP OF CANDLESTICKS, OLD SHEFFIELD PLATED.

Exhibiting types and variation in style for fifty years.

Upper Row-

1780. Broken fluted column. Acanthus leaf decoration, square base, medallion and ribbon ornament.

\section{Lower Row-}

1810. Circular base, spiral fluting. lobe decoration, urn-shaped nozzle retained.
1790. Square base, broken fluted column, terminating in Ionic capital.

1820. Circular base, with bulbous column heavily decorated with floral scrolls.
1795. Square base, tapering column fluted, surmounted by urn nozzle.

1830. Broken circular base, onion-shaped column, bulbous ornament. 

CANDELABRA AND CANDLESTICKS 131

on the easy flow of simple line. It is composite in character, it betrays a lack of inspiration. It is a very poor relation to the fine table candlesticks of the earlier period, where the beauty wins and fascinates. There is no such grace and distinction in these late examples, but they doubtless reflected the silver fashions then prevalent, which were in the main execrable in taste. 

IV

SALT CELLARS AND MUSTARD POTS

THE SALT CELLARS

THE PATTERN BOOKS OF SHEFFIELD

THE NEW STYLE OF TABLE SALT CELLAR

THE MUSTARD POT

A BID FOR THE CONTINENTAL TRADE 

CHAPTER IV

\section{SALT CELLARS AND MUSTARD POTS}

The salt cellars-The pattern books of Sheffield-The new style of table salt cellar-The mustard pot$A$ bid for the Continental trade.

THERE is nothing so ancient and so massive about the salt cellars that Sheffield made as there is in the old styles beloved by the collector of rare silver plate. There are no standing salts in Sheffield plate, such as those treasured at the Universities, or brought out on state occasions at the dinners of the great London Companies. There is nothing in the eighteenth century in silver approaching the grandeur affected by the standing salt and its place of honour at the tables when those who sat above the vessel and those who sat below it were of different status. The trencher salts of a later day were more democratic ; they were smaller and they answered the practical purpose of serving salt to the diners. But they had nothing of the stateliness of the great standing salt with its ritual as fixed as that of the loving cup which circulated, although the salt was a permanent fixture. Those who sat below the salt 
were either the Greek chorus or they were "preposterous shadows lengthening in the noon-tide of one's prosperity." They were poor relations, " a blot on your scutcheon, a rent in your garment, a death's head at your banquet." Charles Lamb touches on the late eighteenth century phase of the dependent below the salt. "He casually looketh in about dinner-time-when the table is full. He offereth to go away seeing you have company-but is induced to stay. He filleth a chair, and your visitor's two children are accommodated at a side-table. . . . He declareth against fish, the turbot being small-yet suffereth himself to be importuned into a slice, against his first resolution. . . He is a puzzle to the servants, who are fearful of being too obsequious, or not civil enough to him. The guests think they have seen him before. He calleth you by your Christian name, to imply that your other is the same as his own. He is too familiar by half, yet you wish he had less diffidence. With half the familiarity he might pass for a casual dependent; with more boldness he would be in no danger of being taken for what he is. $\mathrm{He}$ is too humble for a friend, yet taketh on him more state than befits a client. $\mathrm{He}$ is a worse guest than a country tenant, inasmuch as he bringeth up no rent. When the company breaks up, he proffereth to go for a coach-and lets the servant go. He recollects your grandfather, and will thrust in some mean and unimportant anecdote of the 

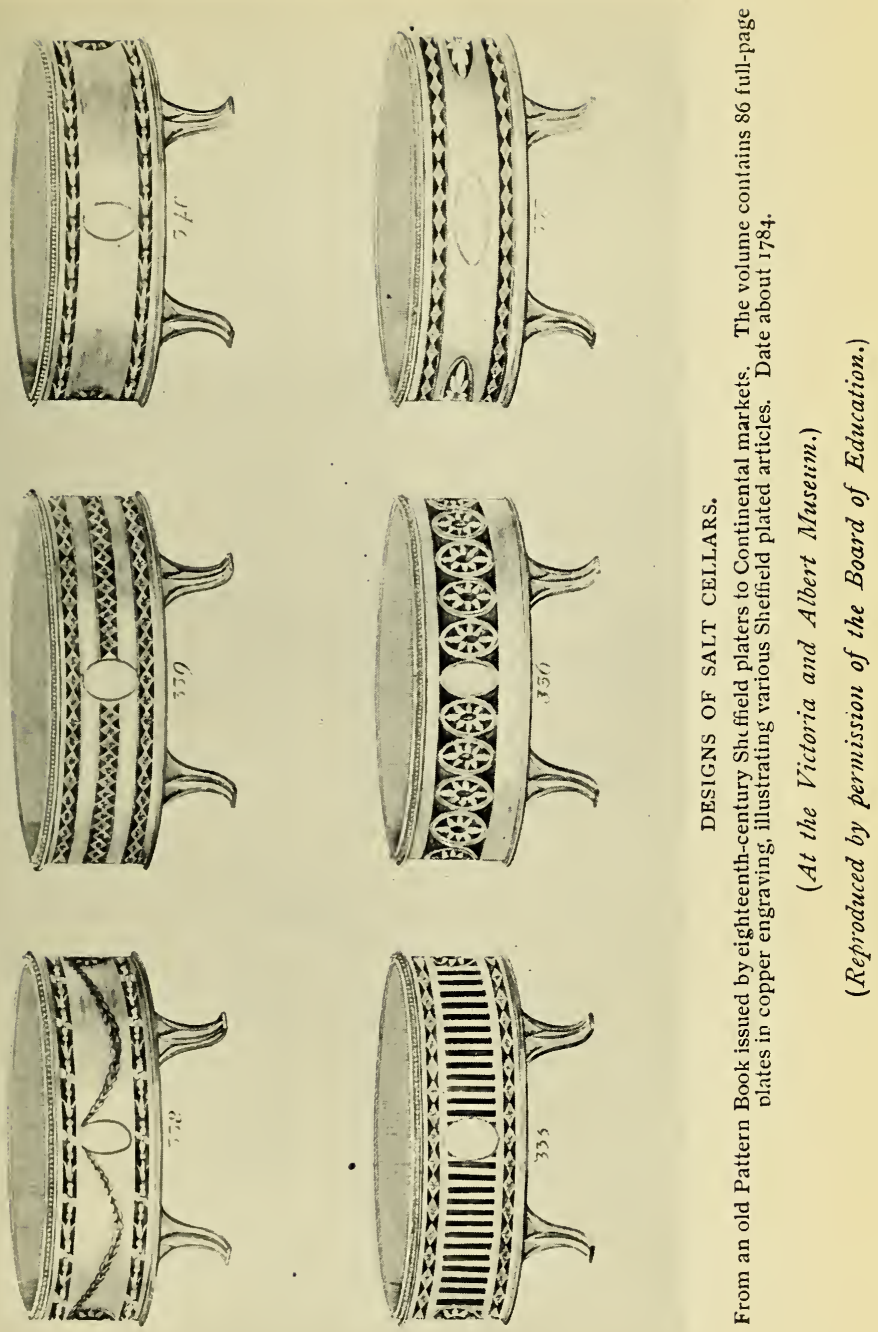



\section{SALT CELLARS AND MUSTARD POTS 189}

family. He knew it when it was not quite so flourishing as ' he is blest in seeing it now.' $\mathrm{He}$ is of opinion that the urn is the more elegant shape; but after all, there was something more comfortable about the old tea kettle-which you must remember."

What a picture, graphic and piquant, of the closing years of the eighteenth century. Had the great standing salt survived how Elia would have revelled in his sly whimsical manner in portraying the exactitude with which it was fixed as a thermometer to register the correctitude of degrees of social affinity with the host. But the scattered plebeian trencher salts, as was the urn, which succeeded the copper kettle, were of the days when Sheffield and the silversmiths ran neck and neck.

The Pattern Books of Sheffield.-Advertisement is often considered to be of modern origin. In the twentieth century it is true it has taken to itself attributes which might very well have been eliminated. The press is the fourth estate, and its power for good or evil is illimitable. It is obnoxious to find a page of advertisement printed on the cheap edition of a novel. It is a stab in the vitals to read an insidiously worded article carefully printed in an evening paper and find it only an advertisement. There is a Plimsoll mark in advertising, and modernity has not always agreed as to where this should be placed. 


\section{CHATS ON OLD SHEFFIELD PLATE}

There were advertisements in the journals of the days of Charles II. In Anne's day in the Spectator we find on June 2, I II2, advertisements concerning a preparation for "polishing and setting Razors, Penknives, and Lancets, not to be paralleled, being much more durable and smooth, never growing rough by using, but setting Razors with greater Fineness and Exactitude than any other sort possibly can. Price Is. each. Sold only by Mr. Allcrafts, a Toy Shop at the Blue-Coat Boy against the Royal Exchange in Cornhill and Mr. Paishon, a Stationer at the Maypole in the Strand."

Sheffield goes back to I624, when the Cutlers Company was incorporated by Act of Parliament. Cutlery and tools were the great features, but later there grew up a special branch known as "steel toys." Button-hooks, corkscrews, key rings, nut-crackers, swivels and spring hooks, and many other articles. Here then was the foundation of trade long established and trade customs long in operation. It is not therefore surprising to find that when the great impulse came with factories and mills arising on every hand for rolling plate and manipulating it into shapes acceptable to the world of fashion, that Sheffield rose to the occasion. Her catalogues, beautifully engraved and costly to produce, were embellished with designs of examples she was prepared to export to the Continent. From these Pattern Books we get a very interesting sidelight into the intricacies 

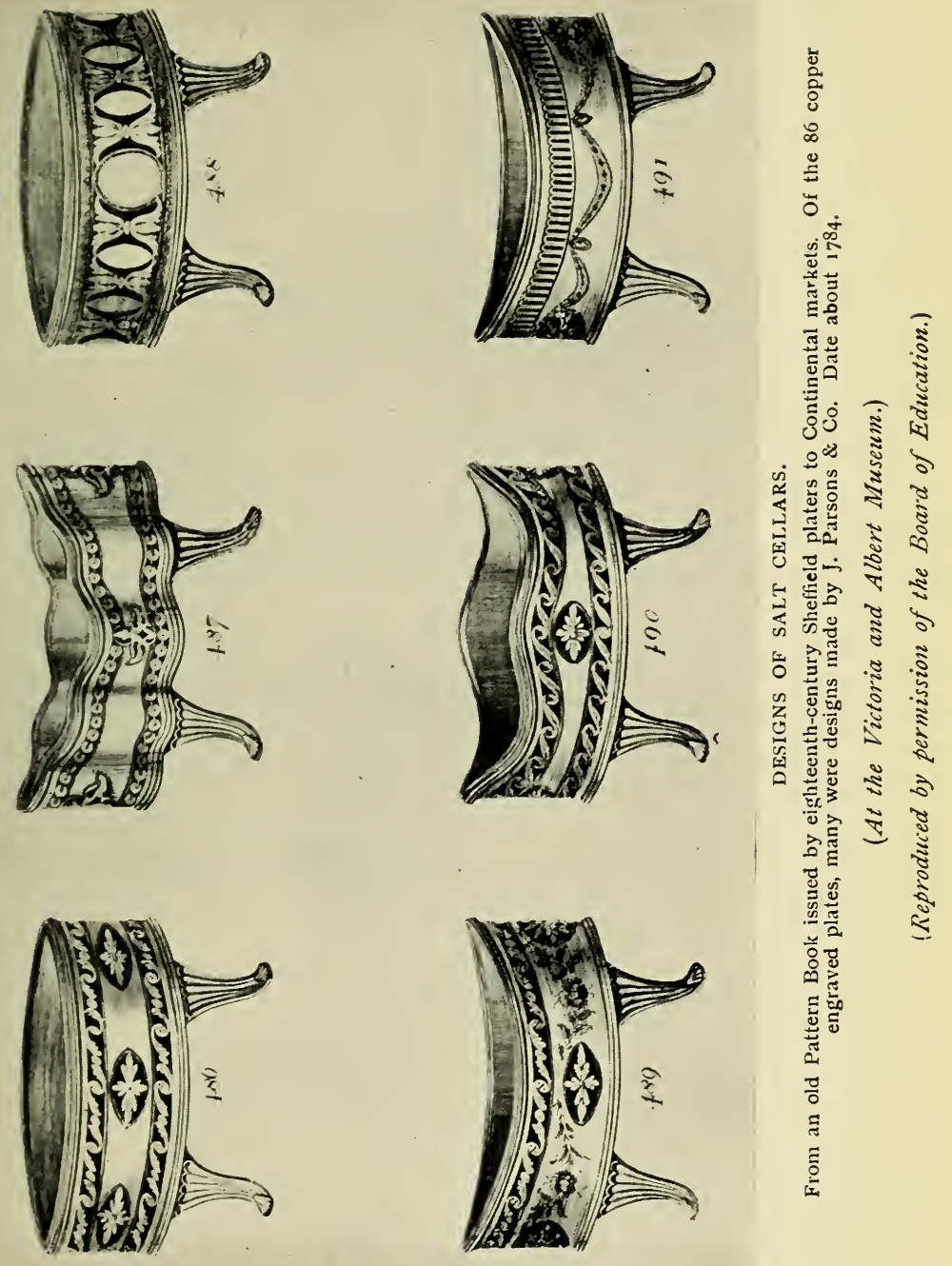



\section{SALT CELLARS AND MUSTARD POTS 143}

of the business side of the undertakings which were evidently on colossal proportions.

In the examination of the designs each by each it will be observed that as is usual in modern trade publications every variation is given of designs differing from each other although in apparently unimportant details to the public. But this peep behind the scenes shows how exact were the traders in illustrating such differences in design.

The point arises as to whether the Sheffield platers themselves made these slight variations in design, adding here a piece of chasing and there a chain of festoons, each article having this slight variation from its fellow, or whether they were actually following the silversmiths' designs in silver plate where similar variations may have been made. We do not know. It is a moot point. If we cannot find in silver, and examples have not always been found to agree exactly with Sheffield plate reproductions, all that we know Sheffield produced we are on the horns of a dilemma. First, some of the silver designs required to indicate originals that Sheffield must have copied are missing and must have been destroyed, or, secondly, some of the designs of Sheffield had no counterpart in silver; that is to say, they were original designs made by the Sheffield silver platers as variations (as the illustrations show) of silver models.

This is an interesting point, and it has never 


\section{CHATS ON OLD SHEFFIELD PLATE}

been quite cleared up, as to whether all Sheffield plated work can be matched by having examples of solid silver plate produced as prototypes from which such models were taken. Until this is done systematically it is not quite certain whether Sheffield did or did not invent certain additions of her own in embellishing designs which originally came from the silversmith. The presumption is that she did; broad general designs as prototypes were used, but details in ornament and decoration and a series of minor differences were made to suit the technique or to offer variety to clients.

An examination of the specimens from the old copper-plate designs (illustrated, p. I37) shows how slight some of the variations in chasing were. No. 338 on the top row on left is similar to No. 340 in same row which latter is minus the festoons. No. 339 has an upright medallion and a central band of chased lozenge ornament. No. 337 has the same design in bands top and bottom, the medallion is sideways and there are added panels of ornament at side.

Another illustration (p. I4I) shows similar minute variations which were offered to the trade. No. 486 on the left at the top row is practically the same as No. 489 , on the second row beneath which has floral chasing added, and the next example, No. 490, differs only inasmuch as it has a broken curved top. The differences therefore are only those found in trade catalogues. 

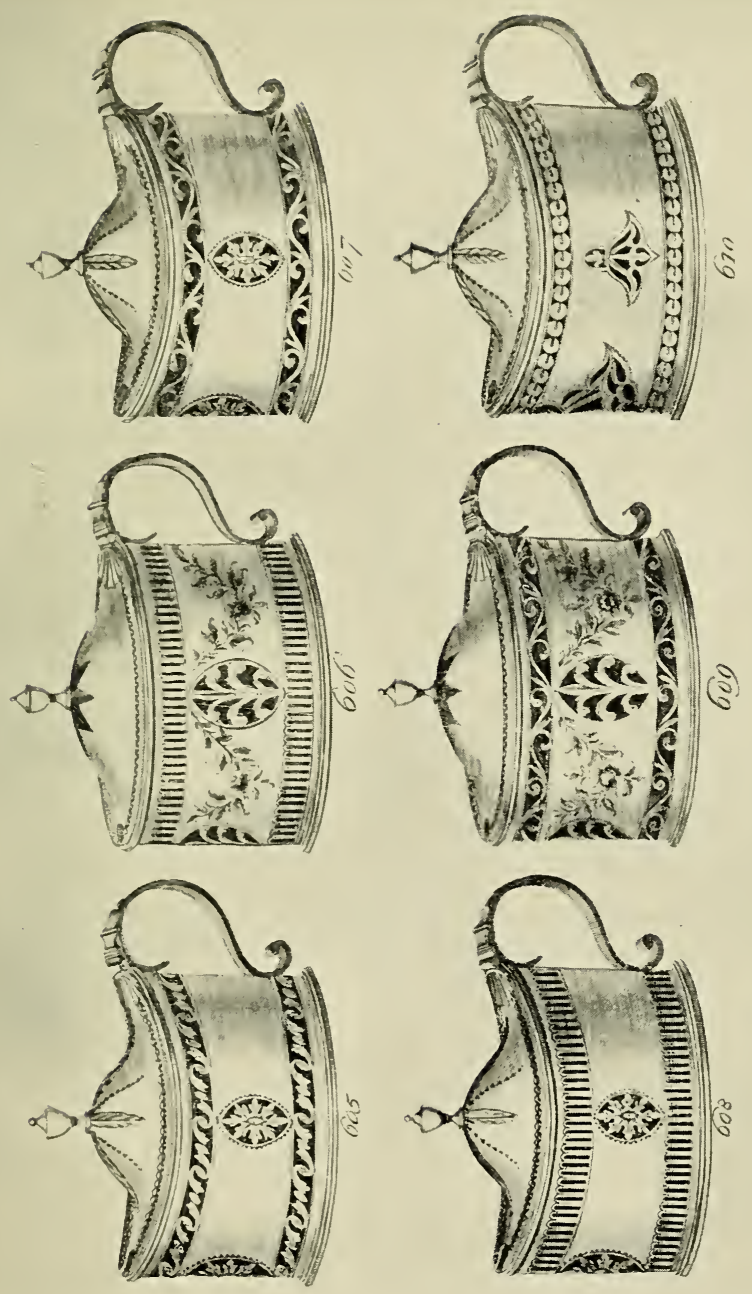

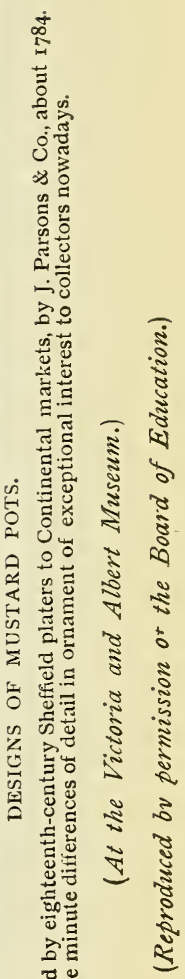

'0 

SALT CELLARS AND MUSTARD POTS 147

\section{The New Style of the Table Salt Cellar.-}

Apart from the days of the great standing salt of the late seventeenth century, the potter followed on at Rouen and at Lambeth with simulations in white ware of these creations of the silversmith. In the days of Queen Anne and in the reign of George II the trencher salt was of minor proportions and simple in design. It had no feet and it did not attempt to be ornamental in the same degree that is observable in later salts where the decorative effect is beautiful and symmetrical and where they followed in succession all the phases of contemporary ornament. They had hoof feet, claw and ball feet, were perforated in their designs, were oval or hexagonal in shape, adopting in turn the classic festoons of the Adam period, and the godrooning of the tureen of the late George III massive style. They had three feet and then four feet, till they finally dropped the foot altogether. When Empire forms were in vogue they are found with sphinxes or winged griffons and on tripod stands, and in the decadence they sunk to trivial designs as inartistic as the crude earthenware butter pan in the dairy.

It is interesting to the collector of old Sheffield plate to trace his designs and compare them with the silver hall-marked specimens throughout the period from I770 till $I 820$. He will find that in the main the Sheffield plated examples of the period about I785 to I795 offer examples in 


\section{CHATS ON OLD SHEFFIELD PLATE}

decorative style not surpassed by any others, and he will also find that the silver plate of that particular period is not quite so replete with similar designs as one would suppose, taking it for granted that all the designs of the platers were taken from the prototypes found in silver.

The Mustard Pot.- "What say you to a piece of , beef and mustard ?" says Shakespeare in his Taming of the Shrew, which shows the use of this condiment at the sixteenth century English table, though there is no record of mustard pots having formed part of the plate. Swift gave certain satiric directions to a servant how to snuff a candle, and he added further injunctions, "Stick your candle in a bottle, a coffee-cup or a mustard pot."

In collecting, the mustard pot bursts on the horizon about the year I760. Fitted with blue glass liners, they ran in triumphant progress with the sugar pails, and cream pails, through a period of thirty to thirty-five years, offering the choicest specimens of cut and pierced work, with festoons and with medallions in classic style, and decorated with exquisite chasing.

Their shapes varied with varying fashions. The illustration (p. I45) taken from an old Design Book by J. Parsons and Co. of Sheffield, about I784, shows the type then fashionable. All these are of oblong form. The lids spring up with fine contour and are chased with various patterns, all of them terminate in an urn pediment, fol- 


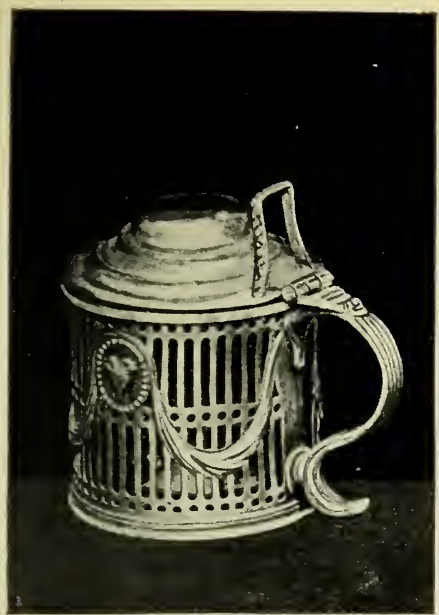

OLD SHEFFIELD

1775. With bar piercing : Medallions and festoons. Circular base; dome lid. Handle of form used on flagons.

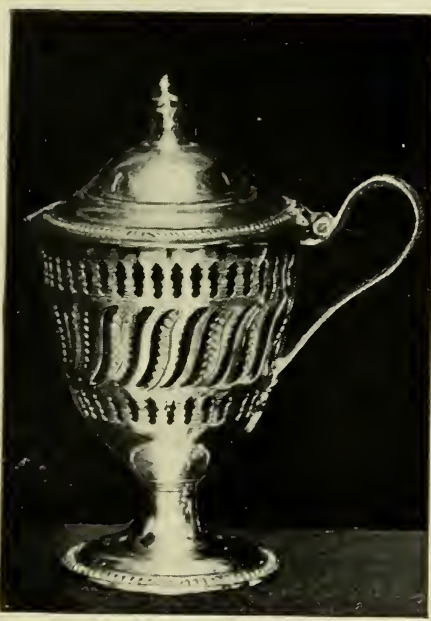

1785. Round in shape on collette foot; scroll piercing. Circular lid surmounted by knob.

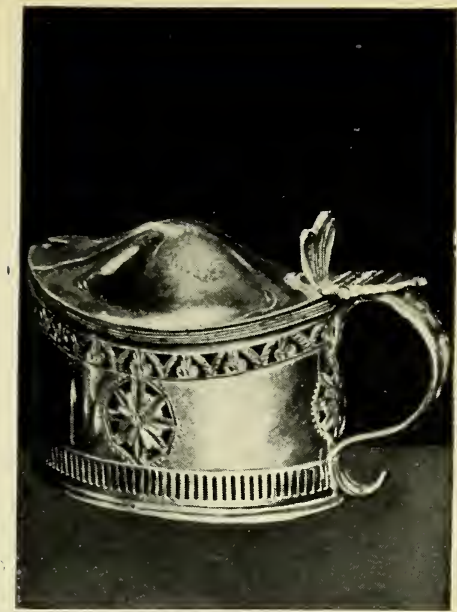

PLATED MUSTARD POTS.

1785. Oval shape. Handle with Prince of Wales's feathers as thumb-piece. Medallion star pierced. Threaded rim.

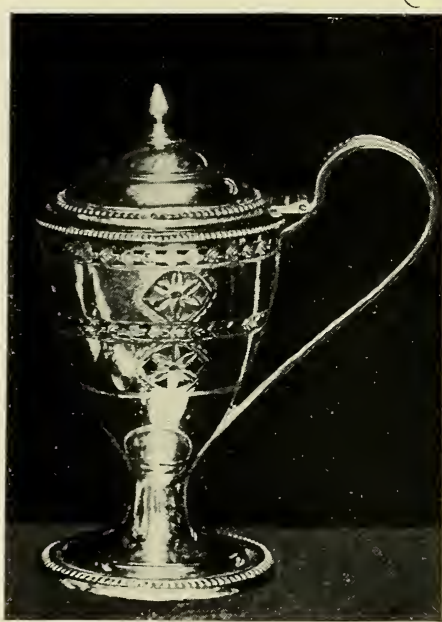

1790. Vase shaped on collette foot. Bead edging and beaded handle. Star piercing.

All these examples have blue glass liners.

(In the collection of B. B. Harrison, Esq.) 


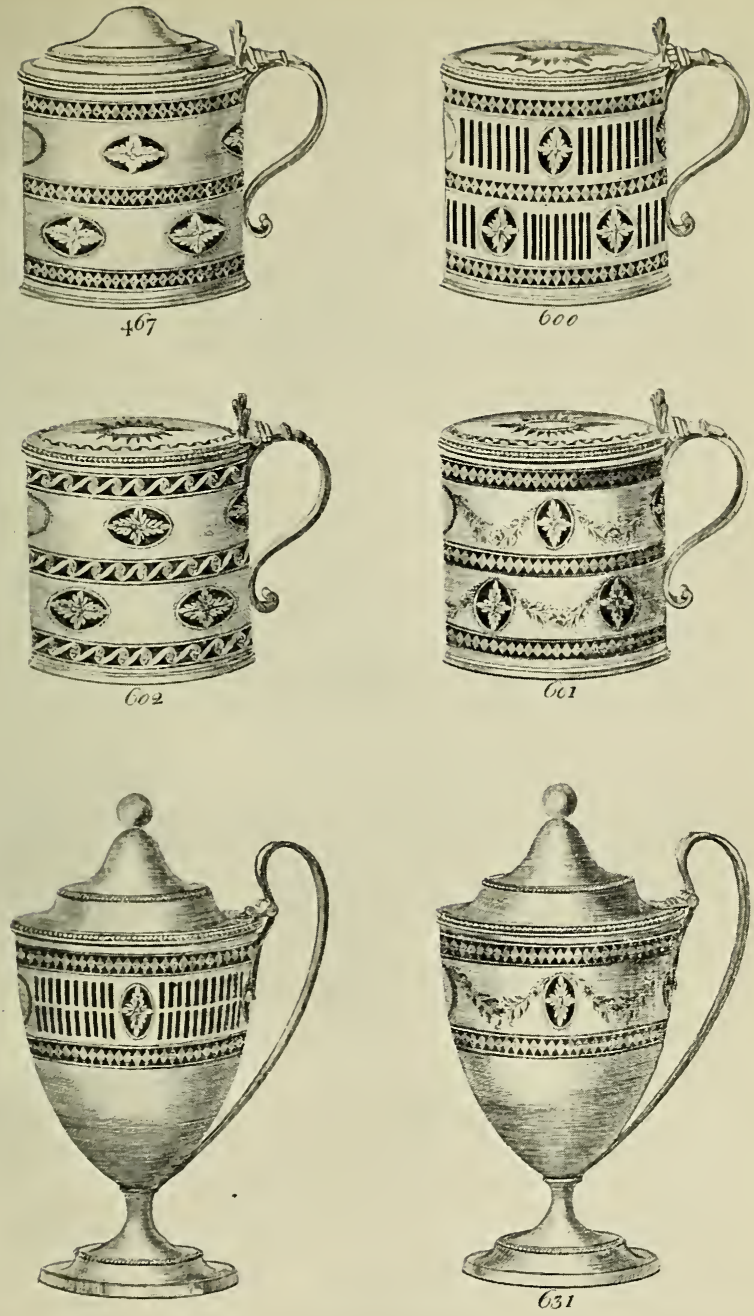

DESIGNS OF MUSTARD POTS.

Fıom an o'f Pattern Brok issued by eighteenth-century Shefficld platers to Continent. ' narkets. Many are by J. Parsons \& Co., abotit 1784 . The fine character of the cut and pierced ornament indicates the artistic nutput of that period.

(At the Victoria and Albert Museum.)

(Reprodused by permission of the Board of Education.) 



\section{SALT CELLARS AND MUSTARD POTS 153}

lowing the prevailing note in decoration. As was shown with salt cellars in regard to these old pattern books the designs are only slight variations from each other, differentiated from each other by numbers for trade reasons. But the differences are trifling, as will be seen from the illustration. The middle examples on the two rows illustrate this. The same ostrich feathers, a simulation of the fleur-de-lys, and later in Hepplewhite manner to be affiliated with the Prince of Wales's feathers as a permanent feature in design. In both examples this is a feature as a pierced medallion. The floral festoons are the same in both cases, but the only variation is the chasing in the upper and lower bands. The other examples show similar relationship.

During the period of classic design there was a drum-shaped upright form as is shown in the illustration (p. I49) with handle and lid, by the way, which go to an earlier period. The adjacent example, I785 in date, is oval, like the copper-plate pattern book examples illustrated, but its character is finer. The pierced designs as in the I775 example are of a fine quality. The thumb piece at the handle, it may be noted, goes back to seventeenth century days and is found in flagons.

Other drum forms are shown in the illustration (p. I5I) and the same slight variations appear in trade differentiations in this copper-plate catalogue of examples ready for export. Some 


\section{CHATS ON OLD SHEFFIELD PLATE}

of these, it will be noticed, have flat lids and one example has the dome-shaped lid of the flagon of earlier days. The tall urn-form offers another variety of shape. It is here shown in the engraved examples and it is further exemplified in two fine examples in date $I 785$ and $I 790$, illustrated (p. I49). In the left hand specimen the pierced work exhibits an originality and beauty in its curved perforations. The other mustard pot has pierced star ornament and delicate beaded decoration, on body and handle. In regard to the handles of these urn mustard pots there is a departure from exact classic countour. The illustration ( $\mathrm{p}$. I5I) shows the handles in fine curve, but severely classic. The practical examples have lost this severity, the handles are more the handles of the working silversmith than the designs of the drawing master. In regard to Sheraton's design books there are similar differences. The practical craftsman did not always live up to the ideal of the designer.

A page of mustard pots illustrated (p. I55) shows the diversity of the styles, and collectors can compare their Sheffield plate not only with marked examples of silver but with designs that were issued from Sheffield in the series of Pattern Books which happily have not been destroyed. A page of pepper castors illustrated (p. I55) shows similar inventiveness in design and ornament.

\section{A Bid for Continental Trade.-The series}



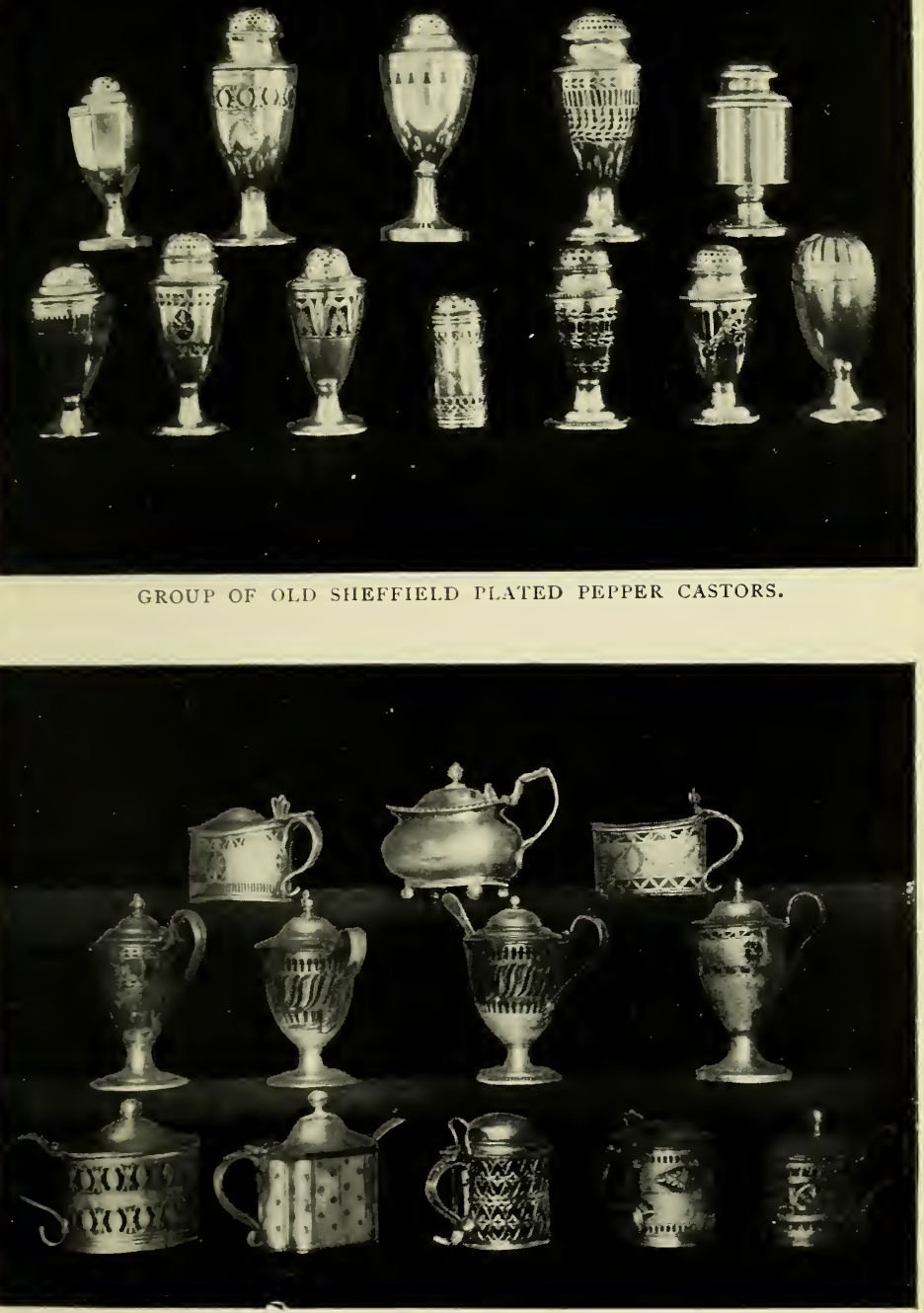

GROUP OF OLD SIIEFFIELD PLATED MUSTARD POTS.

(In the collection of B. B. Harrison, Esq.) 



\section{SALT CELLARS AND MUSTARD POTS 157}

of illustrations reproduced throughout the volume show that Sheffield was organized and fully equipped as an art industry, ready and competent to seize foreign markets. To those who imagine that the Sheffield silver plating process was something comparatively trivial, wholly imitative, and more or less of little moment in reckoning the eighteenth century art industries in England, this should come as a shock. We do not remember that Worcester or Derby, Chelsea or Bow, our much vaunted porcelain factories, ever had much relationship with the Continent in the way of trade. Wedgwood did, and the other Staffordshire potters did, because they were more organized than the porcelain factories. It is interesting, therefore, to find that on the Continent a demand had arisen for English metal work. The metalsmiths on the Continent were by no means deficient in originality. For centuries in Italy and in Holland, in Germany and in France, some of the finest workers in gold and silver, in brass and iron, artists in jewels and in enamel, had won a great renown. It is somewhat flattering to find that the foreigner saw, what perhaps was less recognized in the country of its origin, that the work of the Sheffield silver platers stood on a plane apart. And their flattering attentions were not only confined to purchasing replicas of fine English silver. Whether they bought it as being useful from a trade point of view to copy English silver designs, as a short cut to getting 


\section{CHATS ON OLD SHEFFIELD PLATE}

fine models, or whether they loved it for its own sake as a cheap and as a beautiful reproduction of fine designs, we cannot determine, but they did the Sheffield platers the honour of copying their technique and there are some fine examples of their work. In France, plated ware in the Sheffield manner was manufactured. We illustrate a coffee pot of no mean design (p. 2II) of French workmanship, and it is stated that in Holland and in Russia similar imitations of the Sheffield technique were made. Special marks were compulsory for this plated ware in the country of its origin in order to prevent its sale as solid silver plate. Two French marks illustrated (p. 29I) show the words Doublé (copied) or Plaqué (plated) together with figures denoting the quantity of the silver. 
CAKE BASKETS

DECANTER STANDS OR

COASTERS

\section{DISH RINGS}

INKSTANDS AND

TAPER HOLDERS 



\section{CHAPTER V}

Cake baskets - Decanter stands or Coasters-Dish rings-Inkstands and taper holders.

As the days wore on at Sheffield the technique, as collectors know, became amazingly perfect. The silver wire following the intricate outlines of a vessel disguising the raw edges of the copper, was used in a manner unequalled by the craftsman in silver plate because he had no need of such artifices to conceal in his technique the poverty of the base. He was working in a solid metal where no base metal at every conceivable point thrust itself into prominence. He could engrave deeply with no possibility of going too deep and betraying the shining copper. His applied ornament was solid silver, and here the Sheffield plater runs parallel in regard to die work and soldering parts together. But, in all, the Sheffield plater was more skilled, his die work is delicate and exhibits no noticeable trace as to its extraneousness. He may be compared with the artist in veneer of the same or an earlier period. The perfection of applied veneer and the exquisite skill employed by the cabinet-maker in covering oak with fine figured mahogany is unsurpassed. 


\section{CHATS ON OLD SHEFFIELD PLATE}

Veneers have in modern days been so skilfully made until they are no thicker than a cigarette paper, the modern glue and the modern processes have worked on scientific lines, although in many respects they have not outrivalled the old worker in veneers. Similarly, in Sheffield plate, the great note of exclamation, surprising and wonderful, is at the wire edged work, the handling of dies in a subtle and delicate manner, and the great result produced by a difficult technique. Stage by stage the Sheffield platers increased their facility for cunning handicraft. Machinery they had, and clean-cut differentiation of task. In fact the various branches soon became specialized in such a great industry. There were the die sinkers, and the workmen who fashioned dies and the workmen who fitted them ingeniously in position were others than those who soldered candlesticks together. The candlestick makers became a separate industry. Piercing and cutting, and the designs for this craft, soon became separate and were carried to a great point of perfection. Chasing as a craft and the designs for chasing as an art it may readily be believed formed another separate branch. From the preparation and fusing of the copper and silver, the rolling of the ingot, to the later stages of artistic technique, so great and extensive an art industry systematized itself into component working parts. But through it all runs like a silver thread the intensity of the magical working of wire. Wire, unheeded by 


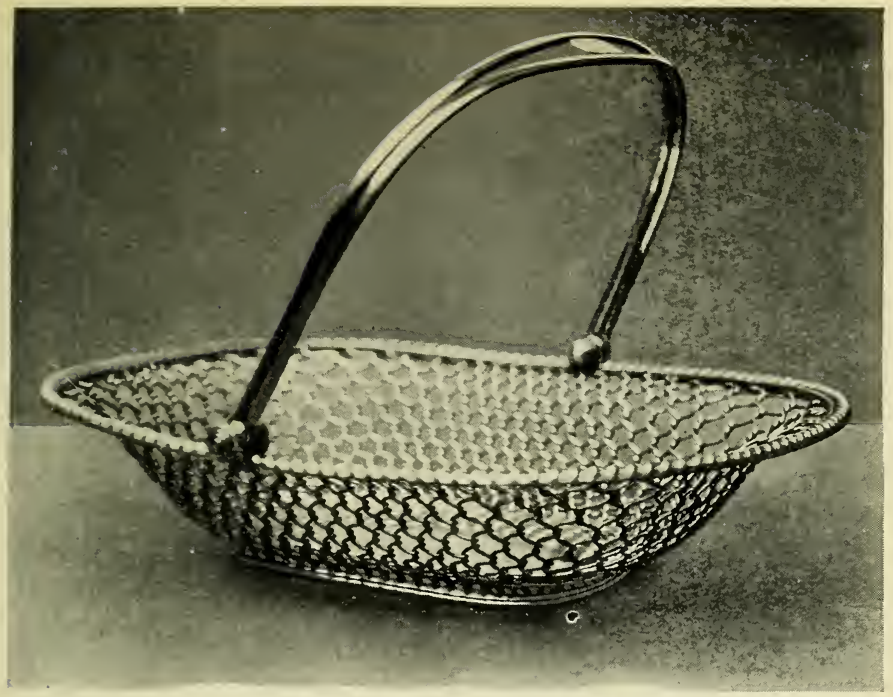

OLD SHEFFIELD PLATED CAKE BASKET.

Woren wirework with gadroon border, with handle in plain double bands and hinged. Date 1800.

(At the Sheffield Public Museum.)

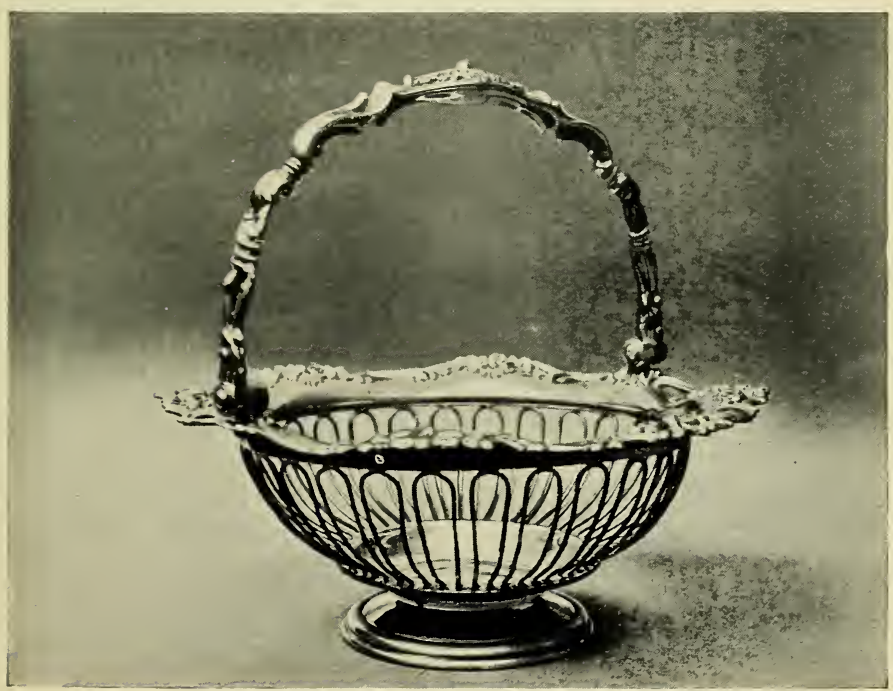

OLD SHEFFIELD PLATED CAKE BASKET.

With circular base : having wire body surmounted by a broad lip heavily decorated with foral ornament: massive handle with hinges. Date 1810 . Diameter $9 \frac{1}{2}$ in. Base 4 in.

(At the Sheffield Public Museum.)

(Reproduced by permission of the Corporation of Sheffield.) 

the tyro but beloved by the connoisseur, converted copper and silver, with its too obvious copper edge into solid plate to all appearance. It duplicated all with which the silversmith could endow his plate and it represented toil and infinite pains, the genius of Sheffield, in producing results which are unequalled as tours de force in metal technique.

Cake Baskets. - The cake or bread basket offered a fine field for free manipulation of the sheet silver, for fine pierced-work, or designs classic and severe, or urn-shaped and massive. All these are found, and Sheffield plate cake baskets are always sought after by collectors as offering something delectable in design and exquisite in detail.

The example illustrated (p. I63) is composite in its technique. The broad solid band as a rim has pierced ornament, as has also the foot. The body of the basket is wire work. The hinged handle is a solid band. A fine woven wire example, in date 1800 , has a gadroon border, with handle with double bands and hinged. This is in simple basket form. The woven wire follows the technique or simulates the character of a plaited straw basket, just as Wedgwood ware baskets and dishes simulated the plaited and interlaced rush baskets. One must compare Sheffield plate with the silver examples by Edward Romer and William Plummer about I760. A later example, in date I8Io, illustrated (p. I63) has a circular base from which springs a wire body surmounted 


\section{CHATS ON OLD SHEFFIELD PLATE}

by a broad lip or rim heavily decorated with floral ornament, and having massive handle with hinges. The touches of extraneous ornament indicate the departure from the wire worker's reticence and simplicity. The design is debased from such simplicity as is found in pure wire work by these added floral ornaments. Lightness and grace are the keynotes in wire work and here they are destroyed by the unwanted additions.

Decanter Stands or Coasters.-This is a great family. At first glance it would not seem that there was much room for variation in articles designed for so simple an object as holding a bottle or a decanter and preventing it staining the polished mahogany table. But an examination of various types shows how inventive was the Sheffield designer in producing original shapes of great diversity of character.

In regard to ornament they received the elaborate attention of the piercer who allowed his designs to attain a rich quality only excelled by the dish rings to which reference is made later. They were circular, they had broken tops with flowing curves, or they were octagonal. They had richly gadrooned edges or fine beadwork, or in some examples they had four handles reminiscent of decorative ornament of an earlier period.

The four examples illustrated (p. I67) illustrate types which were being made from 1785 to I79o. They are all from pairs, and each exhibits repre- 

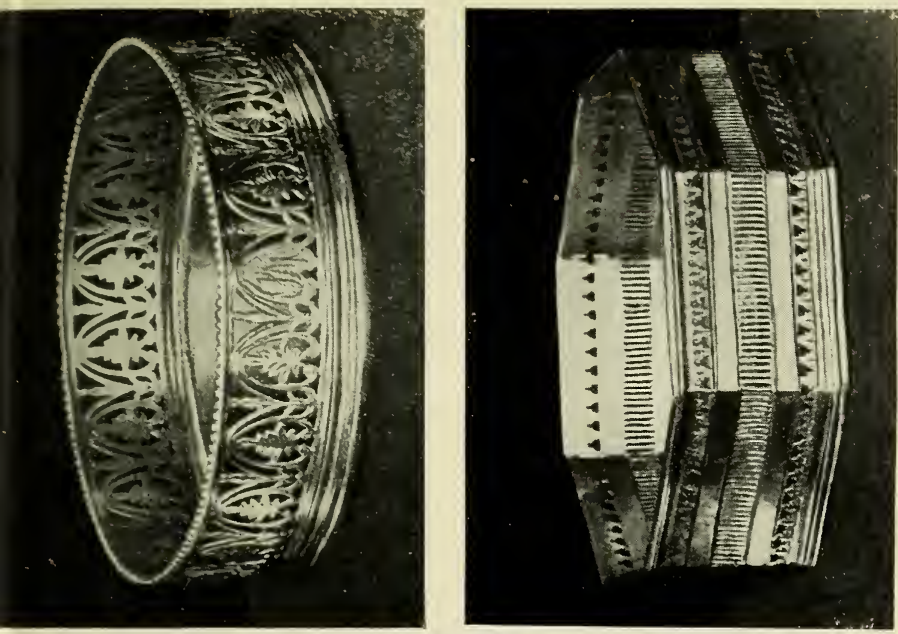

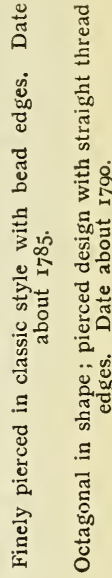

है

空

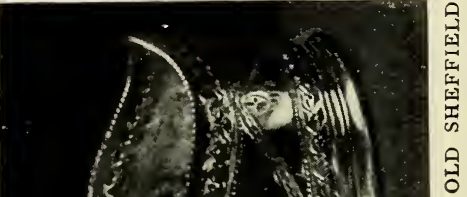

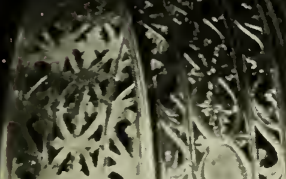

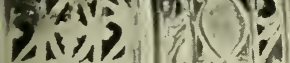
crive Nivis its $\rightarrow$ ite

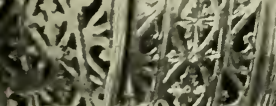
arist

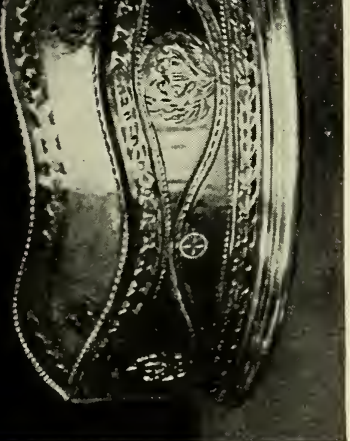

के चू है

ปูป

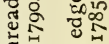

武诘范

चंत्

苋苟

चु

总

离 思 



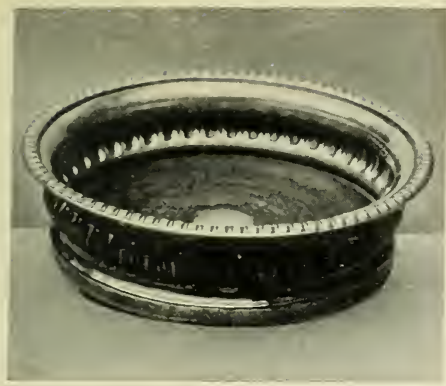

OLD SHEFFIELD PLATED COASTERS.

With broad beaded pattern; having turned wooden bottom with silver boss in centre. Date I8Io. Diameter $5 \frac{7}{8}$ in.

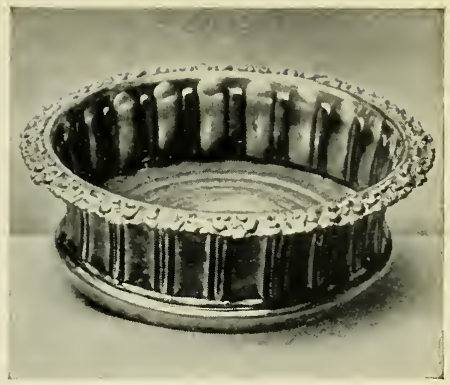

Vertically fluted : with moulded border of scroll design. Turned wooden bottom with plated boss in centre. Date 18 I $_{5}$. Diameter $6 \frac{1}{8}$ in.

(At the Sheffield Public Museum.)

(By permission of the Corporation of Sheffield.)

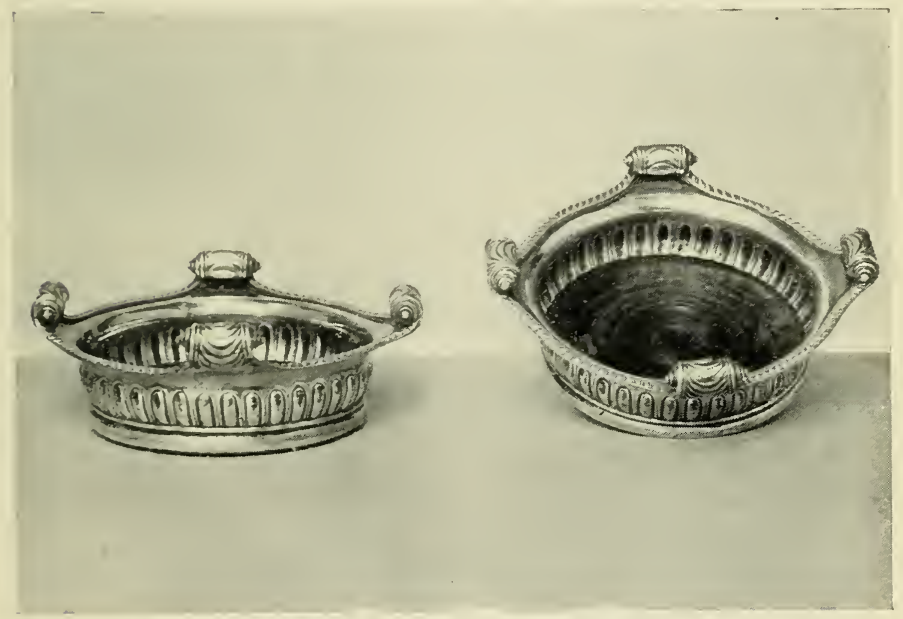

OLD SHEFFIELD PLATED COASTERS.

Circular bases with turned wooden bottoms. Rims with gadrooned edges terminating in four raised scroll ornaments. Date 1805 .

(In the collection of G. H. Wallis, Esq., F.S.A.) 



\section{DECANTER STANDS OR COASTERS 171}

sentative features. The earlier form was not quite so deep as is found in later coasters. In later examples the height is twice that of the earliest type. Perhaps it was found that bottles or decanters were apt to fall over as the evening wore on, but it is certain that the protective guard became higher, and some of the tallest can be used quite comfortably nowadays to hold a syphon of soda. The elaborate pierced floriate work in the 1785 Coaster (p. I67) is classical in character, and it has bead edges and stands as an excellent piece of workmanship. The adjacent example, I790, is seen to be taller though still not so tall as were made at a later date, in the decadence. The pierced work is less effective and may be compared with some of the designs on what are known as Irish dish rings or potato rings. It has threaded and plain edges.

A departure from the circular top is shown in the lower example, of 1785 in date, with pierced and chased work of rosettes and festoons. Its broken curved top rim is decorated with bead edges. The other octagonal shaped specimen, in date $\mathrm{I} 790$, is pierced in reticent manner corresponding with its geometric form, and has straight thread edges. -

At the opening of the nineteenth century new forms came into vogue, the pair of Coasters illustrated (p. I69) are of an unusual design where four scrolls ornament the rims. These scrolls have the suggestion of French First Empire 


\section{CHATS ON OLD SHEFFIELD PLATE}

decorative work found in domestic ornament and embodying bronze work sphinxes, griffons and other bold designs adapted reminiscent of Herculaneum. These coasters have turned wooden bottoms.

Another Coaster (p. I69), in date I8Io, has a broad beaded pattern at edge and a turned wooden bottom with a silver boss in the centre. This particular style has become a favourite and has been duplicated indefinitely and is known as familiarly the world over. In this it resembles the success of the willow pattern plate which, as a piece of pseudo-Chinese design, won the admiration of the public in the eighteenth century, and has been made by all the Staffordshire potters almost as a stock pattern.

On the same page is a later Decanter Stand, about $\mathrm{I} \mathrm{I} 5$ in date, having a turned wooden bottom with silver boss in centre. It is vertically fluted, and has a heavy moulded border of scroll design. It will be seen how far this example has departed from the fine character of the types which were being made in the great period prior to I790. The love for ornament ran riot. It was misplaced and heavy mouldings and solid ornaments were added to articles that could not stand such meaningless exuberances and carefully executed details which choked all natural simplicity of line.

Restlessness of invention seized the Sheffield and other platers. Old forms were discarded, not 


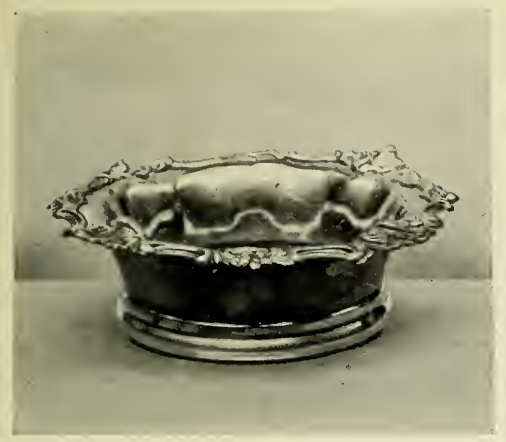

OLD SHEFFIELD PI.ATED COASTERS.

Lip decorated with scalloped floral design. Turned wooden bottom with plated boss. Date 1820.

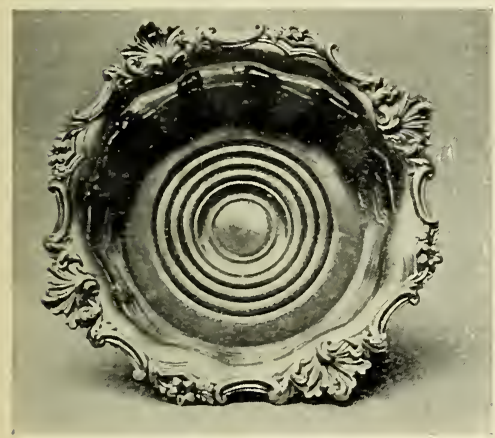

Interior of above. Diameter $6 \frac{1}{8}$ in.

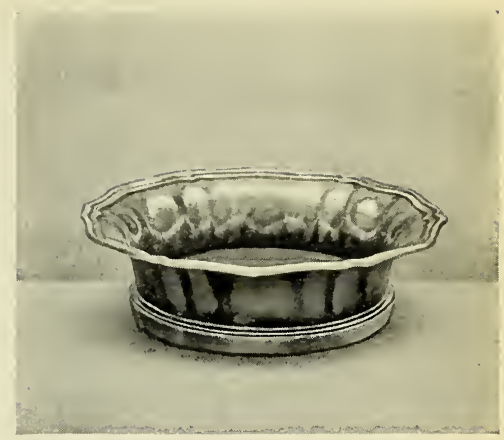

With moulcled edçe and bioadly fluted. Turned wooden bottom with plated boss. Date 1805 .

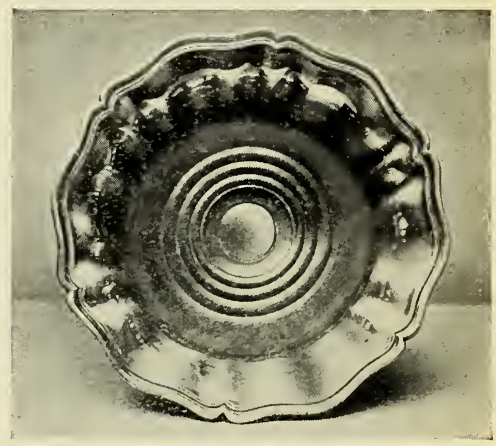

Interior of above. Diameter $6 \frac{3}{4}$ in.

(At the Sheffield Public Museum.)

(Reproduced by permission of the Corporation of Sheffield.) 



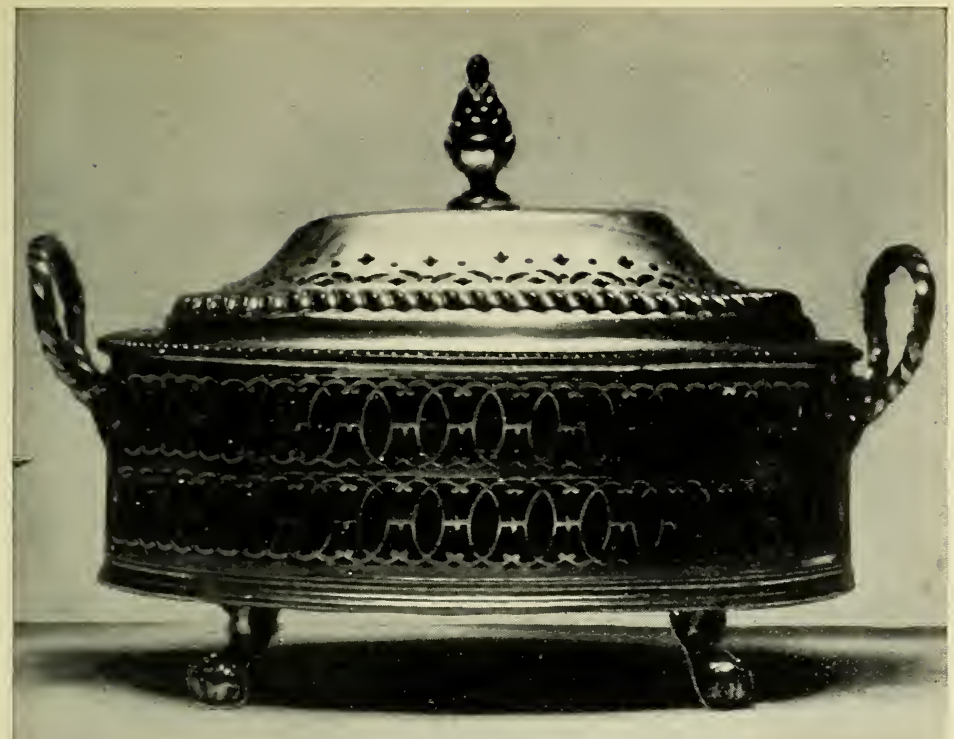

OLD SHEFFIELD PLATED BUTTER DISH.

Oval, finely pierced, having cliased lid surmounted by pineapple. Twisted wire handles , on four claw and ball feet. Blue glass liner. Date about 1785 .

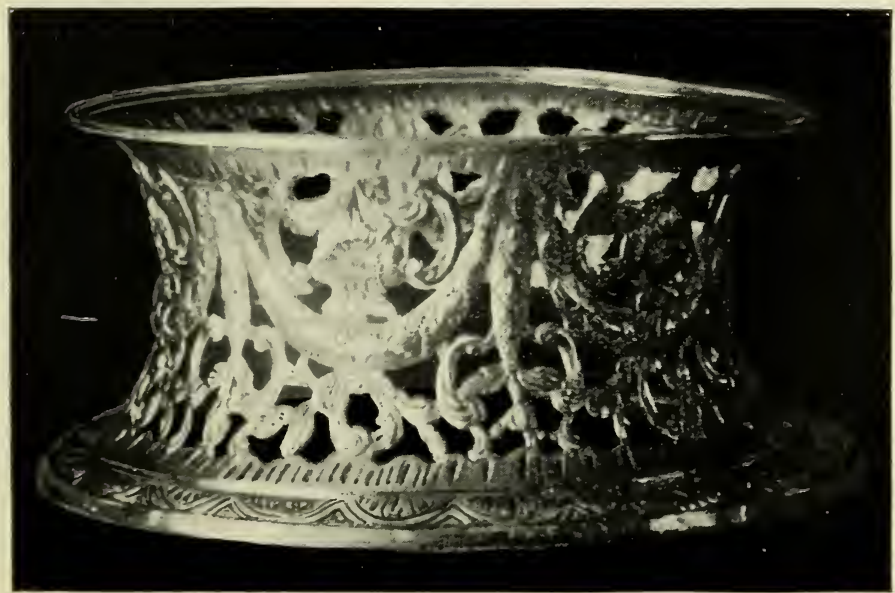

OLD SILVER PLATED DISH RING.

Pierced ornament of floral design and scrolls. Date I775. Made in imitation of Irish silver Dish or Potato Rings.

(In the collection of B. B. Harrison, Esq.) 

because they had outlived their usefulness, but because fashion demanded or appeared to demand something new. The decanter stand began to have its lip spread out more like a dish than like the early form of coaster. Some were decorated lavishly with scalloped floral design as in the example illustrated (p. I73), in date I820. An illustration of the vessel upturned shows the crowded character of the design. The wooden turned base has the usual silver stud or boss in centre. The adjacent example, fifteen years earlier, shows a finely moulded edge broadly fluted. The character of this example is not open to any criticism as to over lavishness of ornament. It is true it exhibits a newer style, but it holds its own as a fine and comparatively reticent piece of design.

The Dish or Potato Ring.-The Irish silversmiths were particularly ingenious in their pierced work. Will Hughes at Dublin about I770 made some interesting pieces reflecting the sanest art. There was always a dignity and grace in the decoration which was strongly classical in its lines, embodying medallions and rosettes and festoons of drapery. The Dish Ring or Potato Ring is a form peculiar to Ireland. It was only made for a comparatively short period, and has been revived again as a modern memory of old fashions, though its use is not quite understood nowadays. These rings are stands upon which bowls were placed to prevent the hot vessel from injuring the 


\section{CHATS ON OLD SHEFFIELD PLATE}

surface of the mahogany table. They are also believed to have supported wooden bowls containing potatoes. Genuine Irish examples are always circular. Bowl and dish were synonymous terms in the late eighteenth and early nineteenth centuries, hence probably the term "Dish Ring." They were made as early as I760. There is a marked example with the Dublin hall mark for that year, together with the maker's mark, Robert Calderwood. Large prices have been paid for examples of old Irish silver dish rings. £I29 was given for an example hall-marked 1757 , and other prices range from $£ 50$ to as high as $£ 25^{\circ}$; in view of their slight weight this works out in some instances at two hundred and thirty shillings per oz.

Examples of Irish work are sometimes apparently simple, but having such careful technique and skilful manipulation of the design as to give the greatest opportunity for the effective play of light and shade and silhouette. Another form more intricate embraced the use of birds and flowers and miniature pastoral scenes embossed, while a more simple form yet capable of fine character was that which confined itself to basket work with round or flat wire interlaced.

It is natural therefore that the Sheffield silver workers saw in the Irish dish ring a design worthy of imitation; and imitate it they did. In consequence a great number of plated replicas were exported to Ireland. They have an interest, and the example illustrated ( $p$. I75) shows the 

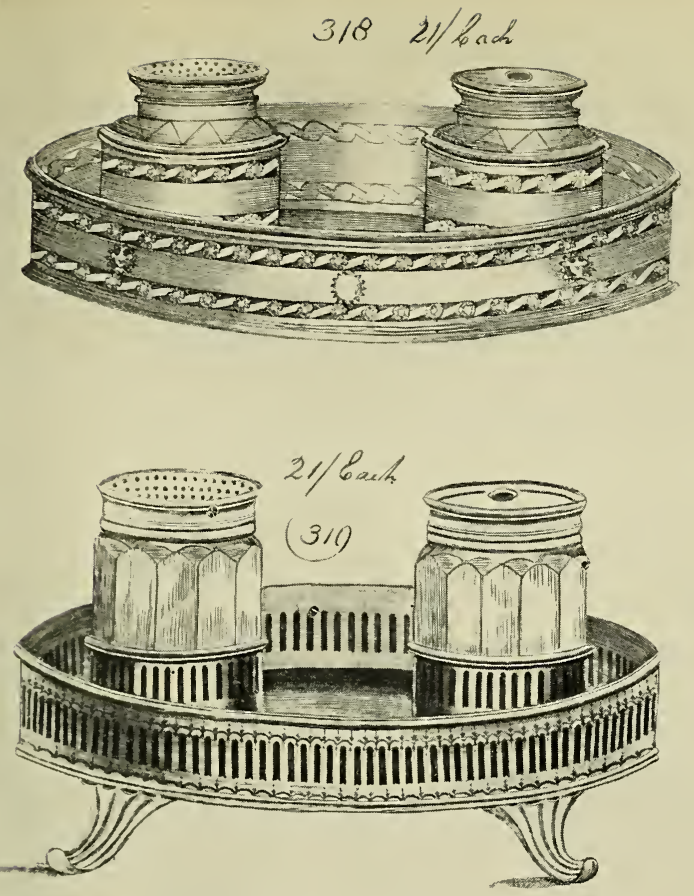

$32030 /$ bud

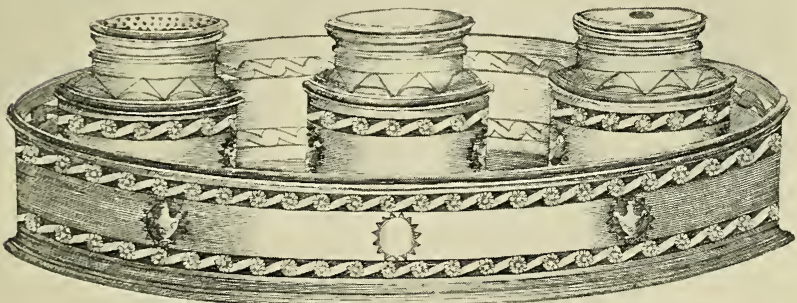

DESIGNS OF INKSTANDS.

From Pattern Book of eighteenth-century Sheffield platers' work; issued by J. Parsons \& Co. about I792. The left-hand examples with perforated lid are pounce boxes. The lower stand is priced at 30 s., the others at 2Is. each cash, and the book is signed "Jno. Green, escompte $30 \%$."

(At the Victoria and Albert Museum.)

(Reproduced by permission of the Board of Education.) 

class of work the Sheffield craftsmen turned out in emulation of their Irish silver prototypes. It is an ordinary pierced design embellished with festoons. Some of the Sheffield examples were finely pierced and chased in a manner no less perfect than the same class of work one finds on the sugar pails, the mustard pots, and the salt cellars of the best period. The Butter Dish illustrated (p. I75) fully exemplifies this type of work at its best. It is oval and finely pierced with an unusual design giving in silhouette the effect of diaper ornament. It is on four ball and claw feet, and the lid is chased and is surmounted by a pineapple. The handles are twisted. These vessels, like the others enumerated above with pierced work, are furnished with blue glass liners, and these collectors are fortunate who find bargains with the original glass liners.

Inkstands and Taper Holders.-The old Sheffield plated inkstand is beloved by collectors. The oval tray was always an elegant piece of work, either pierced with fine running design over an extended surface as border top and bottom and often chased with medallions. The three examples illustrated (p. I79) are from an eighteenth century Pattern Book issued in 1792 by Messrs. J. Parsons \& Co. of Sheffield. Written in ink on the first page for information of continental buyers is "Jn. Green escompte $30 \%$." Green was one of the partners of the firm. This little book in paper covers has no less 


\section{CHATS ON OLD SHEFFIELD PLATE}

than eighty-four copper plate engravings, and for the delectation of the later collector the prices are written in ink throughout. The prices of the examples illustrated are "2Is. Each" the two top ones, and "30s. Each" the lower example.

It will be seen that the latter has three pots. The pounce pot was always a necessary portion to the old inkstand, being used as a sifter in the days before blotting paper was invented. Fine sand was dusted over the writing. It would appear that the pounce pot with its perforated lid is on the left in all the three examples. The centre pot in the lowest inkstand was additional, though not as one might at first assume for a different coloured ink as the lid has not the same cover as those for ink with a tiny hole in centre. It was apparently a receptacle for some of the appurtenances of the writing table, certainly not pens, for steel nibs were not then invented, and every one wrote with a quill pen which he could sharpen with a penknife. Nowadays the art of cutting a quill by hand is one of the lost arts.

An illustration from a Design Book issued by Robert Cadman and Co. of Sheffield about I797 gives three examples of Taper Holders (p. I83). The nozzle at the top shows the tiny light from the coiled wax taper. The apex of the stand really consists of a miniature candlestick. Two of the stands, as will be seen, have the handles and thumb pieces at the bottom. They are all 


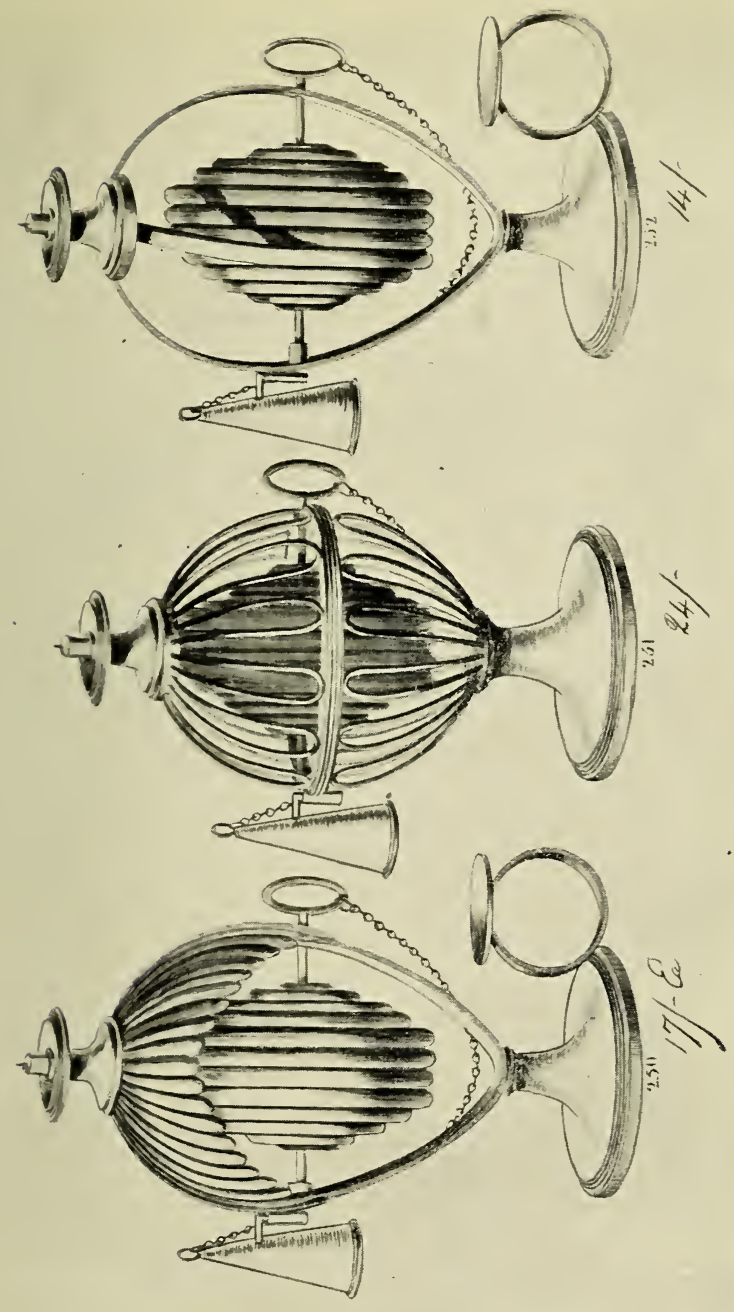

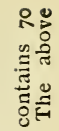

응.

के

हा

总跤

ஸे 류

똥 롱

ज.

얻도

감 0

인

ङ

의을

웅

ज 0

00

놀

㱐

졸

ธี

ค 휴

०ै है

๘

نं $\dot{0}$

$z_{0}^{2}$ \&

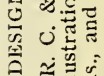

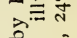

已苞

幽紫

$\because$ 宁

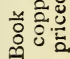

इ불

可

ह

은

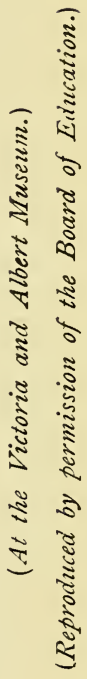





\section{INKSTANDS AND TAPER HOLDERS 185}

of varying form; that on the left has a canopy covering the coiled taper, that in the centre encloses the taper in a wire cage, while the example on the left is the simplest in construction and enables us to see how the taper as it burned was thrust upwards to the aperture at the top. All three have extinguishers attached by a chain. Some of the descriptions in the book from which these designs are reproduced are in French as well as English, as it was intended for use in the Continental markets. 

VI

TEAPOTS

TEA AND

COFFEE SETS

TEA RETTLES

COFFEE POTS

SUGAR BASINS 

Teapots - Tea and coffee sets-Tea kettles-Coffee pots-Sugar basins.

THE eighteenth century of the days of Hogarth, with his Gin Lane and Beer Street and with his satiric pencil reflecting the follies of his day is filled to repletion with eating and drinking, especially the latter. During the later years of George II there had been going on a vigorous protest between two parties as to the relative effects of beer drinking and gin drinking. In I752 appeared a print of the "Funeral Procession of Madame Geneva." A song was very popular in I757 under the title of the "Beer-Drinking Briton." One couplet will suffice to indicate its character:

For your beef eating, beer-drinking Britons are souls

Who will shed their last blood for their country and king.

In 1758 , owing to the scarcity of corn, a bill was passed for the prohibition of the distillation of spirits. Porson wrote a series of epigrams in the Morning Chronicle about Pitt and Dundas going drunk to the House of Commons on the evening when a message was to be delivered from his Majesty relative to war with France. 


\section{CHATS ON OLD SHEFFIELD PLATE}

Pitt, who tried to speak, found himself unable to do so, and was kindly pulled down to his seat by his friends.

"Who's up ?" enquired Burke of a freind at the door.

"Oh! no one," says Sherry, "though Pitt's on the floor."

Sheridan, the maker of the quip, and Porson, the Greek scholar, together make up a fine quartet as exemplifying the Bacchanalian habits of their day.

As to the vessels used in spirit drinking and in wine drinking Sheffield contributed her share. The punch bowl more often than not was of oriental porcelain, but the finely shaped monteiths, where the scalloped rim allowed of a row of glasses being hung around were made as early as I700 by Anthony Nelme, by Fogelberg in I70I, and many another great silversmith. They continued to the middle and latter years of the century, and in Sheffield plate there are some very excellent examples, and there are punch bowls with designs simulating those in the Flaxman manner executed by the silversmith. Ice pails with lion mask handles, and a glorious array of wine coolers, urns in the classic style simple and reticent, or vases with richly godrooned rims and massive handles, such as Roberts and Cadman made in 1815 ; all these were found on the sideboard receiving the attention of the butler.

But the teapot and the coffee pot did not go 


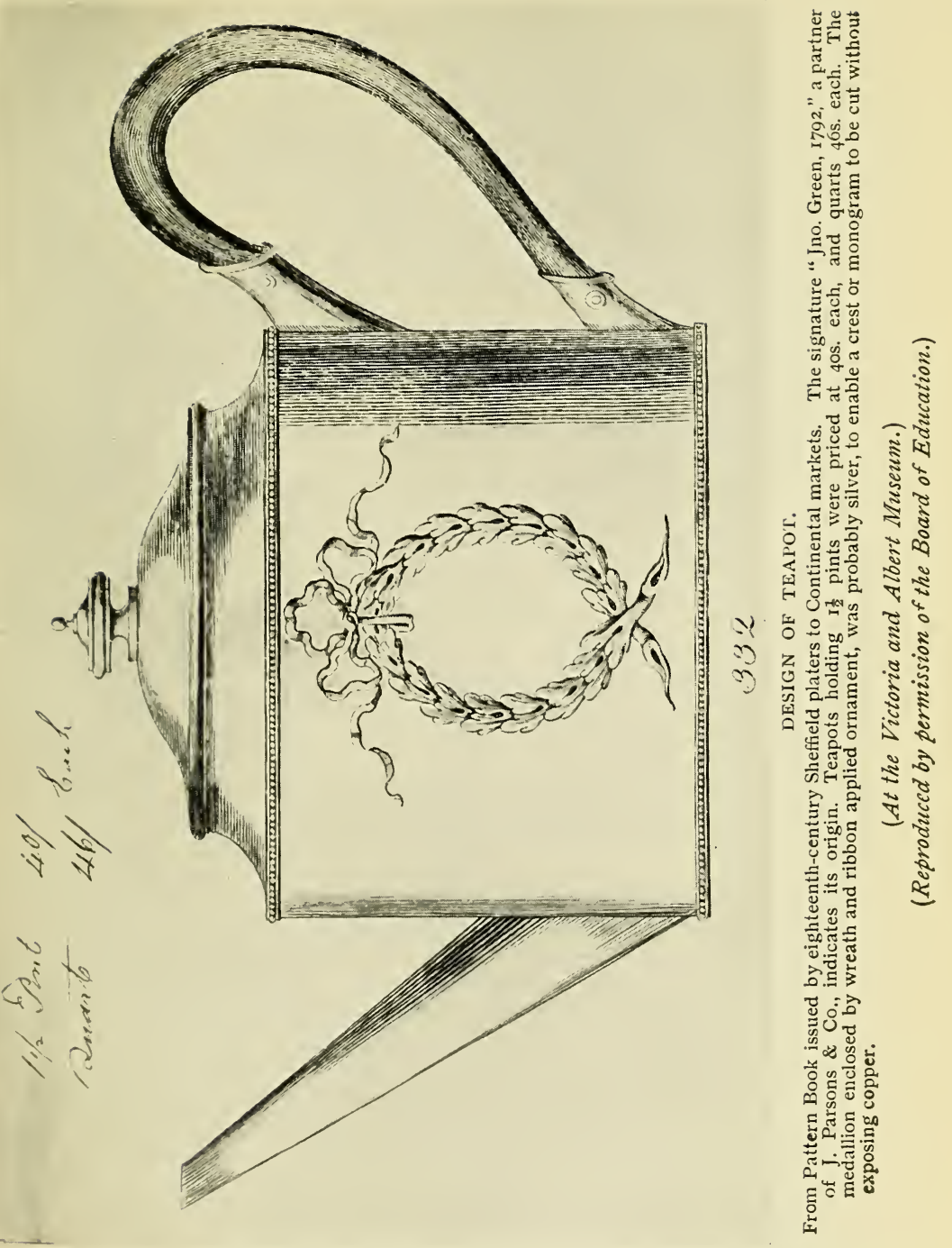





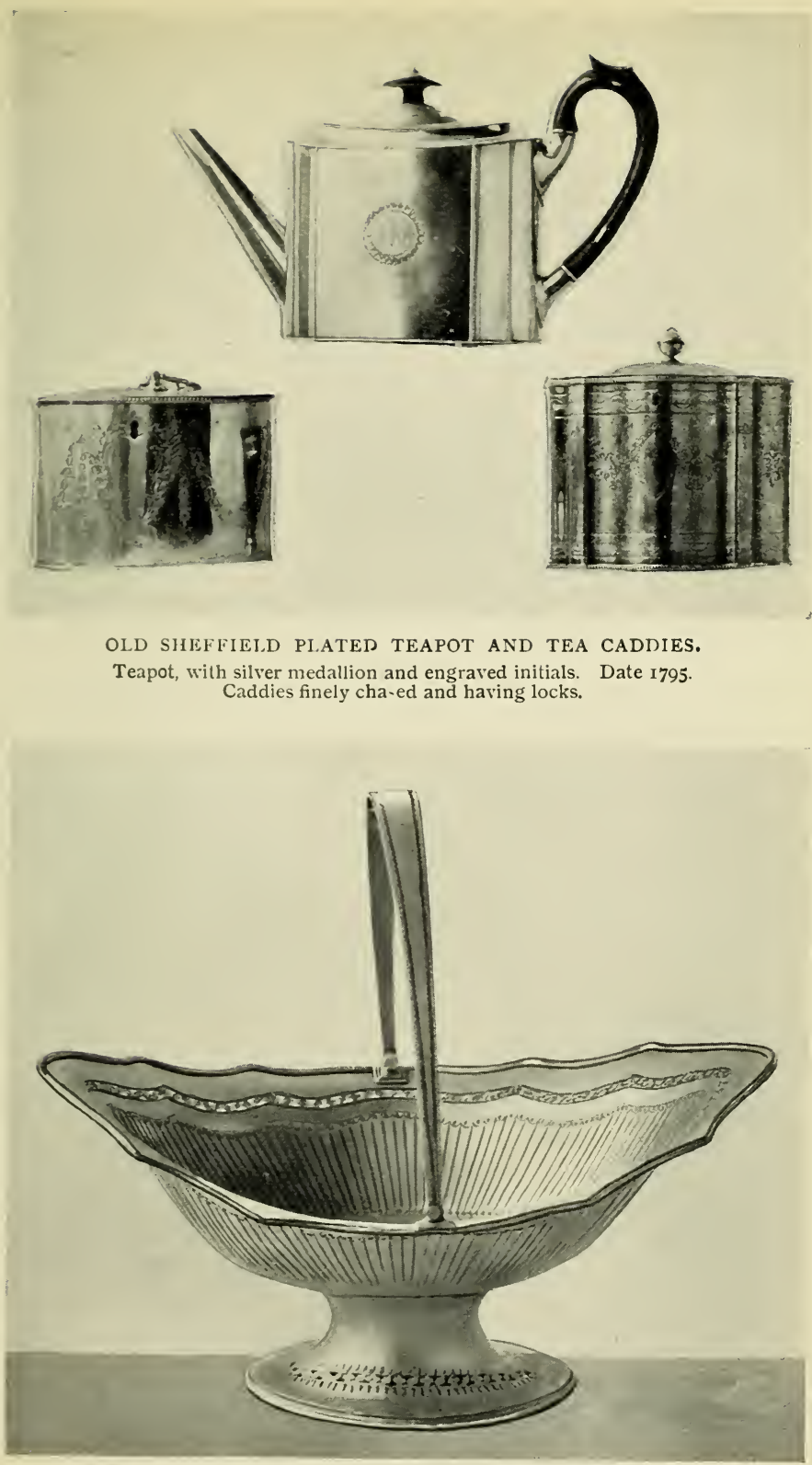

OLD SHEFFIELD PLATED CAKE BASKET.

Plain band-hinged handle. Pierced work at foot and shoulder Shaped and fluted body.

(In the collection of B. B. Harrison, Esq.) 

unrecognized by the Sheffield artisans. What the silversmith did the platers did, and followed the fashions in rapid simulation of styles just catching the public taste. In determining date this must be borne in mind. At most the silver plate was only a year ahead of the replica. Sheffield was too alert to lag behind in fashion, especially in fashions which might readily change.

In eighteenth century polemics we find opponents to tea and to coffee. Jonas Hanway, the eastern traveller, who popularized the use of the umbrella in England, was antagonistic to the use of tea as a national beverage. And epigram writers were busy, as for instance:

If wine be a poison, so is tea-but in another shape,What matter whether we are kill'd by canister or grape.

The illustration (p. IgI) shows the class of teapot made about I790. The price, which is written in ink, is " $\mathrm{I} \frac{1}{2}$ Pints 40s." and "Quart, 46s. Each." These prices must seem delightful to the lover and collector of old Sheffield plate nowadays who has to pay swinging prices, especially when we read that the old trade prices were subject to thirty per cent. discount. But it is the same with old Worcester china, where the original prices were a tenth of what is paid now. An interesting feature about this teapot illustrated is that it shows the fusion of the classic design in the wreath and the Chippendale manner in the ribbon ornament, which latter style finds 


\section{CHATS ON OLD SHEFFIELD PLATE}

its way into bookplates of the period. The French school of engravers of the Louis Seize period embellished their oval portraits with ribbon ornament in this character.

These medallions intended to receive the crest of the owner were of silver. The Sheffield plater affixed them in position in a cunning manner with no unskilful touch. They were capable of receiving deeply cut engraving without exhibiting the copper underneath. They are a feature present in many examples not only of teapots but many other articles made in plated ware.

A similar teapot to the design in the Pattern Book is illustrated (p. I93). The Pattern Book bears the name Jn. Green I792, and as he was a partner in J. Parsons \& Co. there is some likelihood that this is one of their productions. On the same page are two Tea Caddies, oval in shape, with broken outline, in the same fashion as silver tea caddies made about 1785 , and having the characteristics of the Sheraton delicacies in cabinet work. The lid of one is surmounted by a round knob and the other by a hinged handle. They both have locks. The chasing is in classical manner, not so severe as that of the Adam period, but still retaining much of the formal grace of the festoons. The cake basket shown on the same page is contemporary, though it indicates a departure from classic feeling.

The earliest tea caddies came from China and 


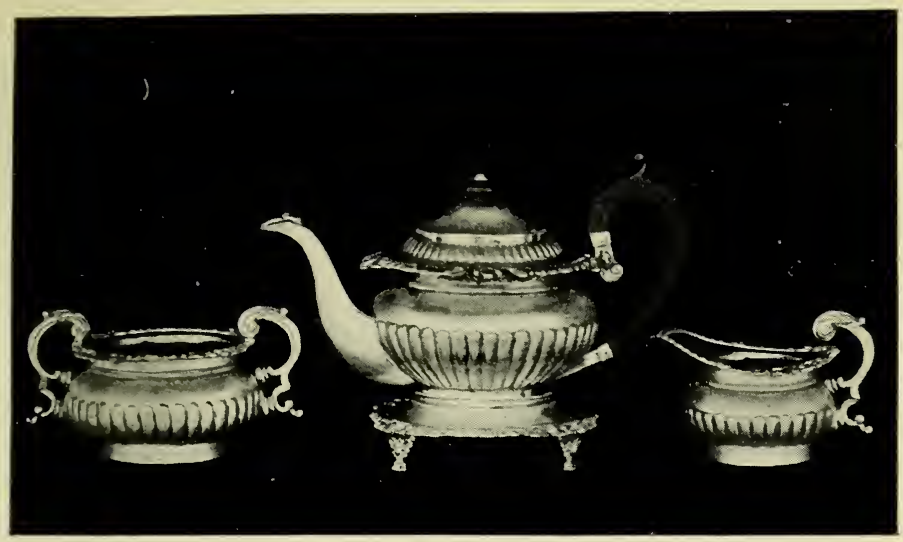

OLD SHEFFIEID PLATED TEAPOT, SUGAR BASIN, AND CREAM JUG. Date 1810.

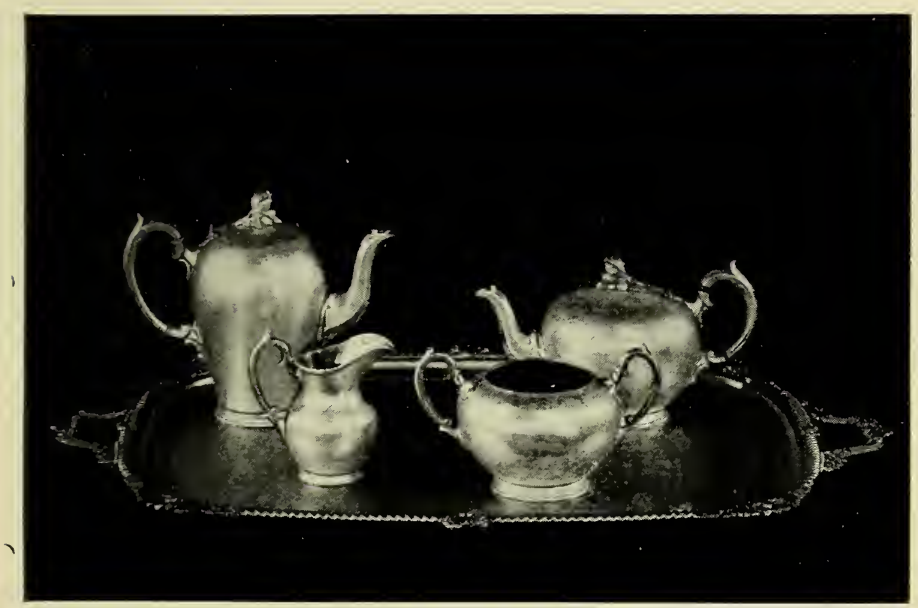

OLD SHEFFIELD PLATED COFFEE POT, TEAPOT, SUGAR BASIN, AND CREAM JUG ON TRAY.

Date 1820 .

Four-piece sets were made after this. 


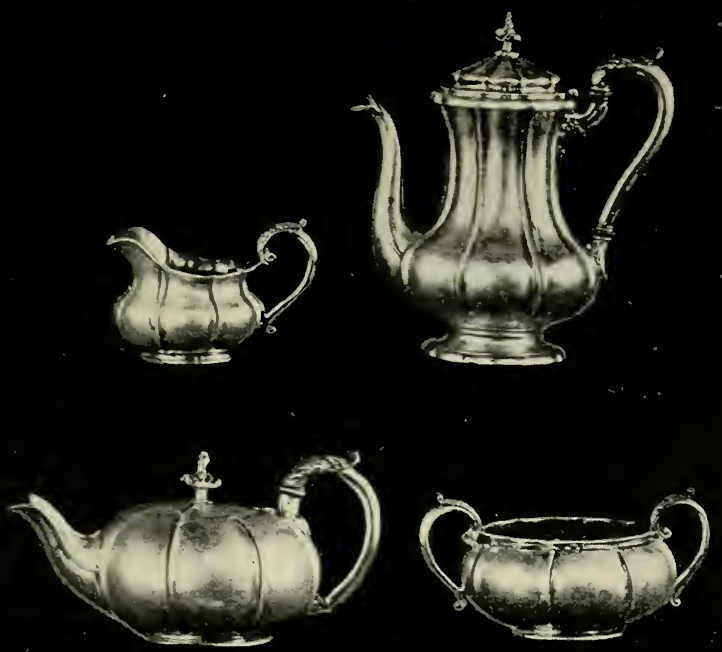

OL.D SHEFFIELD PLATED SET.

Date 1825 .

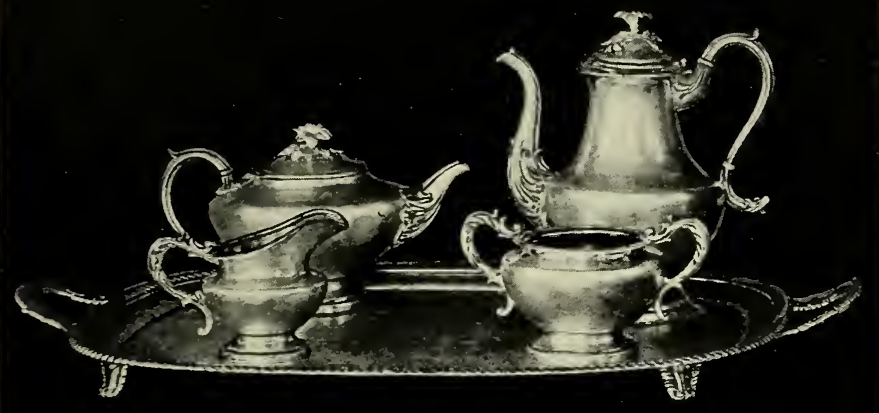

OLD SHEFFIELD PLATED SET WITH TRAY.

Date 1830.

(By courtesy of Waiter H. Willson, Esq.) 

were decorated in blue and white. Worcester produced fine examples, some in powder blue. Whieldon made and dated others "Green Tea, I765." Wedgwood had his square canisters in black basalt ware. Liverpool printed dainty transfer pictures on these dainty caskets. They are found enamelled by Battersea in rich colours. They are found in pewter and they are found in glass. Bristol produced white opaque bottles inscribed "Hyson" and "Bohea," and there are square cut-glass caddies with silver mounts and handles, and in Holland the old Delft examples came with the early days of tea drinking. The cabinet-makers, Chippendale and Hepplewhite and Sheraton, show tea caddies in their Design Books and they were splendid pieces of work in mahogany and satinwood with ivory and coloured marquetry. Many of the little caddy spoons of such pleasing variety of shape were made to go with these tea caddies, and were produced at Sheffield as well as in solid silver.

Tea and Coffee Sets.-It was not until about I 820 to I825 that tea sets were produced with teapot, cream jug, and sugar basin as well as the coffee pot. The set illustrated (p. I97), about I8Io in date, shows this omission. Later in I820, as shown in the illustration below, the coffee pot became part of the set; and in the illustration of the sets it is clearly seen that the styles of the coffee pots are in keeping with the rest of the set and have not been matched or added later. 


\section{CHATS ON OLD SHEFFIELD PLATE}

The four-piece sets became a common feature after the first quarter of the nineteenth century, and some of these are of pleasing character. Two sets, I825 and I830 in date, are illustrated (p. I99). With these were accompanying trays of solid manufacture and about this date they were very heavy and richly ornamented by die work with appliqué shell patterns and foliage at the rims. They only emulated the very solid silver of the late Georgian era when silver was sold by weight by the dealers and so much added for "fashion," that is, fashioning it. This latter item in massive pieces was a comparatively insignificant sum compared with the total cost, which provoked the eighteenth century epigram:

When Loveless married Lady Jenny, Whose beauty was the ready penny;

"I chose her," said he, "like old plate, Not for the fashion but the weight."

The tea urn offered fine opportunities for rich design and splendour of ornament. It was in vogue in the opening years of the nineteenth century and had a fairly long life. Nowadays it is relegated to the lumber-room, or, if the hostess be a collector, it is dragged forth from its obscurity to grace the display of family plate. The example illustrated (p. 203) is on an octagonal stand with claw feet. It belongs to the same period and has the same ornament at the base as the candelabrum illustrated (p. 93) showing First Empire 


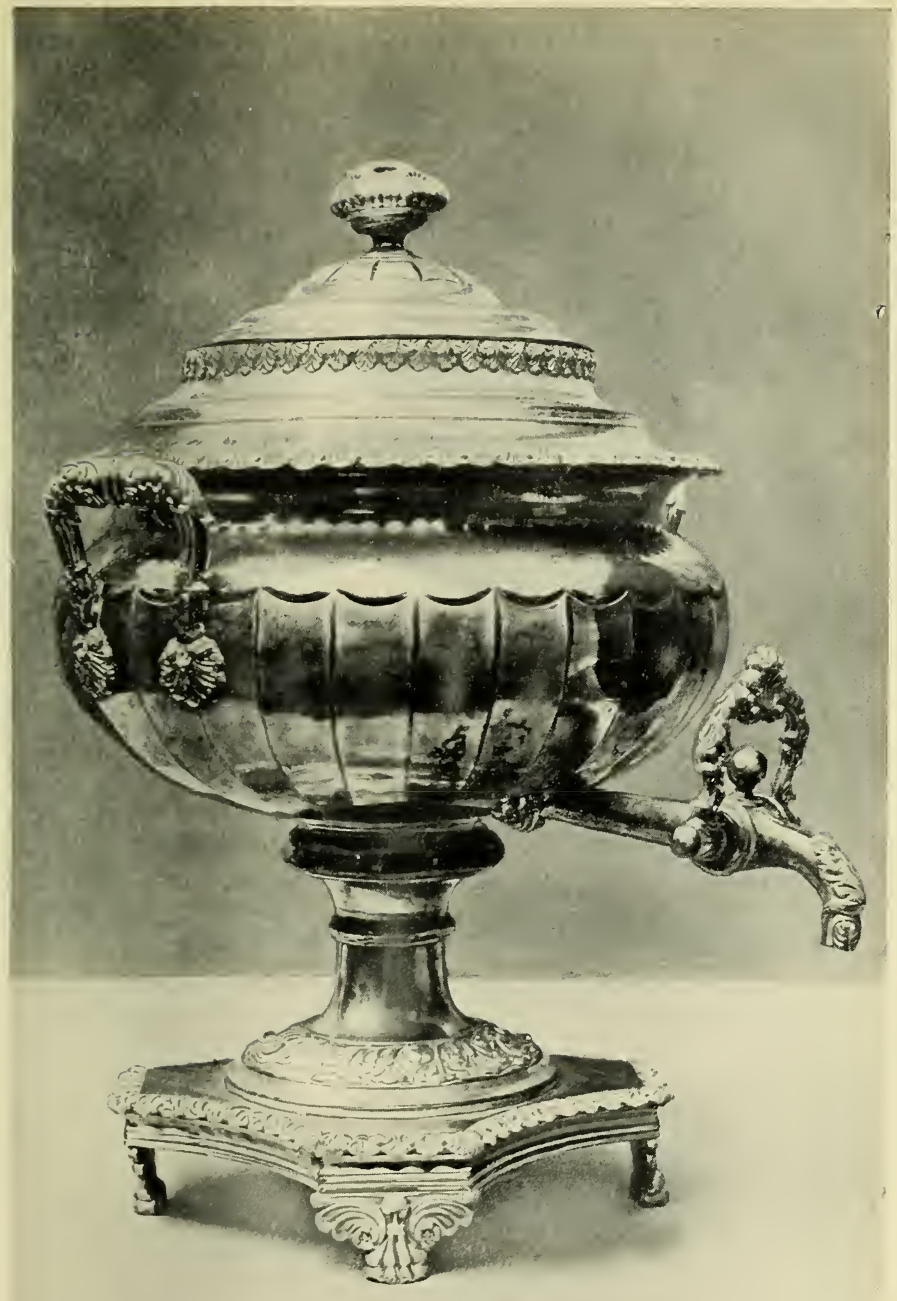

OLD SHEFFIEI.D PLATED TEA URN WITH COVER.

Circular base, to which is attached an octagonal stand on claw feet. Richly decorated rims in floriate style. Date 1810.

(At the Sheffield Public Museum.)

(Keproduced by permission of the Corporation of Sheffield.) 

influence derivative from Pompeii. The whole piece is richly decorated in floriate style. Patrick Robertson of Edinburgh produced tea urns in silver under the same influence.

Tea Kettles.-There is something especially fascinating about these old vessels. As early as Queen Anne, tea kettles with a little spirit lamp beneath were in use. One hall-marked for the year I709 made by N. Locke sold in I909 for $£ 243$, being two hundred shillings per oz. Paul Lamerie made some fine examples just when Thomas Boulsover was launching his invention at Sheffield. It is not surprising to find the Sheffield kettles appealing to connoisseurs because many of them are possessed of beautiful ornament, and the die work is exceptionally perfect. Even in late examples the artistic possibilities of so graceful a vessel have not been missed. They are usually termed tea kettles, and there is no doubt that since the days when Queen Anne drank tea in the Orangery at Kensington Palace and Dr. Johnson graced the tea table of Mrs. Thrale, these vessels were part of the tea table equipment. But there is reason to suppose that they also bore a brave part in preparing the hot water for toddy and for punch. But in any case they hold a firm hold on the collector's esteem and regard, whether he be as austere as Father Mathew, who tilted a lance at spirituous cordials, spiced and unctuous, which, like ginger, were "hot in the mouth," or whether he be as convivial as 


\section{CHATS ON OLD SHEFFIELD PLATE}

Father Prout, whose Bacchanalian songs belong to the days of Bèranger.

The examples illustrated (p. 207) each have pleasing qualities to attract attention. The upper one, in date about I805, has a fine body. Its cover is surmounted with a twisted flame ornament such as is found in candelabra. The ornamental stand is rococo, almost reminiscent of the period of Louis Quinze. But the whole effect, though ornate, is very pleasing.

The lower example, in date I820, the last year of the reign of George III, has a melon-shaped body, and the handle is hinged. The base exhibits rococo ornament in Chippendale manner, suggesting certain designs in his Director which were too ornate to be carried out. They were only designs as suggestions rather than working drawings. But it suggests, too, curiously enough, certain forms of the watch-stand then fashionable. In fact, taken away from its present environment, it might with a very little brazing be used as a support for a watch, that is, if the lower superstructure be taken away.

Coffee Pots.-With so many varieties of coffee pot made by the leading silversmiths Sheffield had no reason to be short of examples. The coffee pot was always taller than the teapot, and it has retained its form to this day, though the earliest teapot known in this country was tall and might well be mistaken for a coffee pot; it is in date 1670 and was presented by George, 

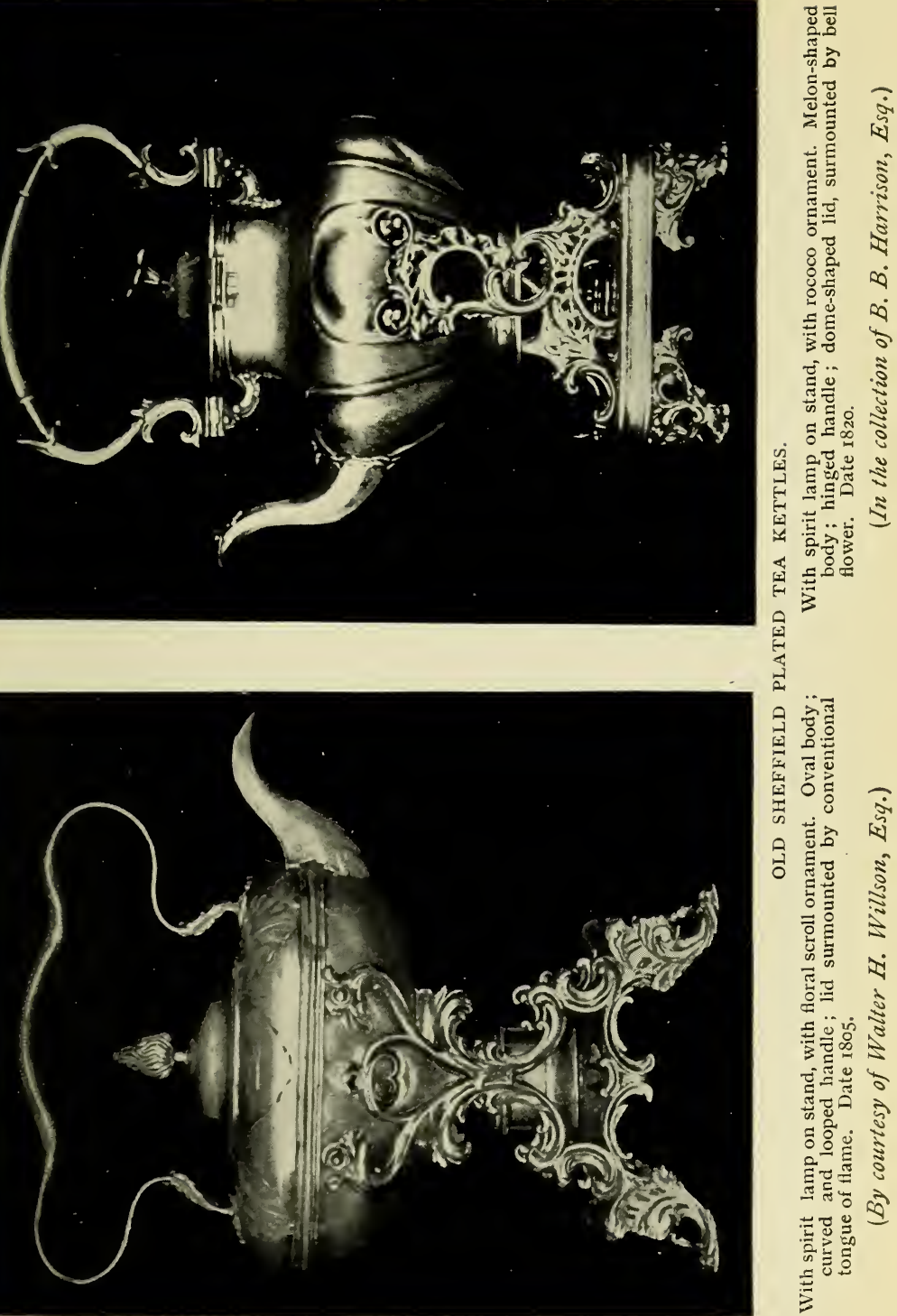

Lord Berkeley, to the Honourable East India Company. They were made in various parts of the country, in London, at Chester, and the marks shown on a coffee pot made at Newcastle-uponTyne, in date I737, of quite the ordinary form in use to-day, are given in the Appendix (p. 279).

The illustration (p. 2II) shows an example of silver plated ware made in the Sheffield manner by fusion and rolling which was made in France. Its body is oviform. It has three legs, which terminate in claw feet. At their juncture with the body there is an ornament of conventional honeysuckle pattern produced by die work. The shoulder is decorated by a band of classic ornament. The cover is surmounted by an acorn. The spout is moulded in the form of a dragon's head, a form found in a coffee pot made by Patrick Robertson of Edinburgh in I769, and in the Royal Scottish Museum, Edinburgh. The handle is wood. There is no doubt about the character of this piece. It is un-English in its design, though it undoubtedly duplicates the technique of Sheffield. It bears the French mark of "Io.M," illustrated in Appendix (p. 29I), the highest quality of plated ware, and has the additional stamp Plaqué (plated) without which no plated articles could be sold in France. The French law in regard to plated goods is severe. "The punch of each maker de doublé or de plaqué has a particular form determined by the Administrator of the Mint. The maker also indicates on his works the numerals 


\section{CHATS ON OLD SHEFFIELD PLATE}

denoting the quantity of silver which they contain."

In regard to plating on copper or any other baser metal the worker can employ silver in any proportion he may desire. But he is required by law " to place upon each of his works his own punch determined by the Mint (as stated in article above quoted). He shall also add to the stamp numerals indicating the quantity of silver contained in his work, on which also shall be impressed in full the word double." And this is exactly what the French craftsmen have done as shown by the illustrated marks given in Appendix (p. 29I).

The Sugar Basin. - The earliest form of the sugar basin was that with a glass liner and capable of receiving highly ornamental pierced work. They were not always of the same height as is shown by the two examples illustrated (p. 2II). The oviform surface of the vessel lent itself to broad bands of decoration and lozenge work in combination with the pierced design. The handles were hinged. These sugar pails as they are often called, although there is the cream pail with liner to which it is more suitable to apply the term " pail," offer delightful variety in treatment, and the number turned out by Sheffield indicate that they were exceptionally popular at the date of their manufacture. We find them about I770 to about I795. In their early form they were classic basins decorated with medallions and festoons and having elongated handles. 'S. and J. 


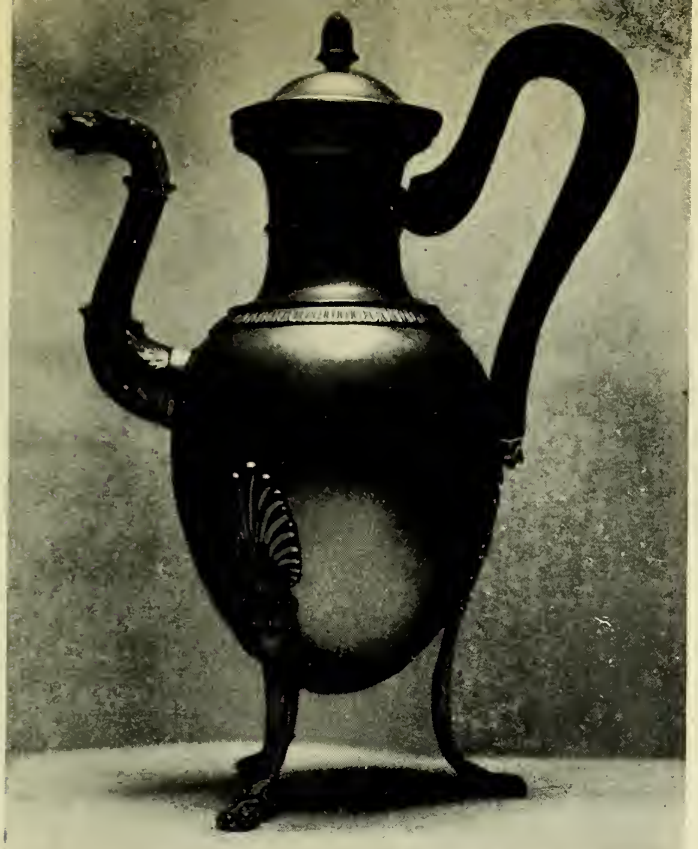

OLD FRENCH SILVER-PLATED COFFEE POT.

Made in the Sheffield manner. Ovoid body; wooden handle; dragon spout. Applied classic ornament, terminating in three legs on claw and ball feet. For marks see p. 291. Date I815-1820.

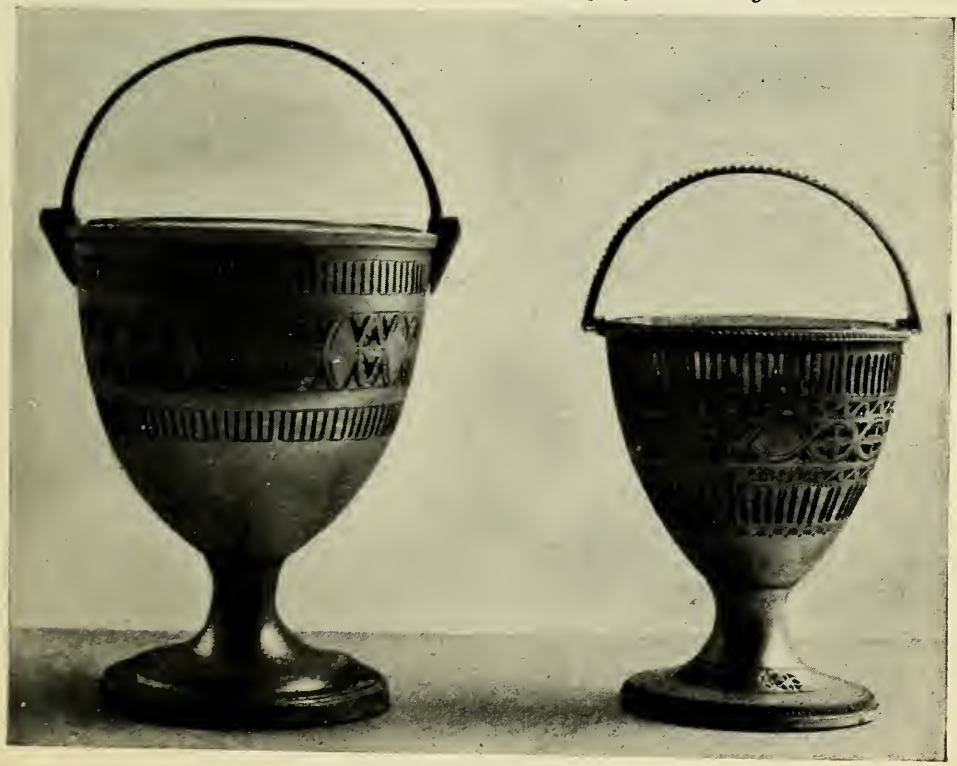

OLD SHEFFIELD SUGAR BASKETS.

Circular on collette foot, with fine pierced work. Blue glass liner.

Threaded handle, date 1790 . Beaded handle, date 1775 .

(In the collection of B. B. Harrison, Esq.) 


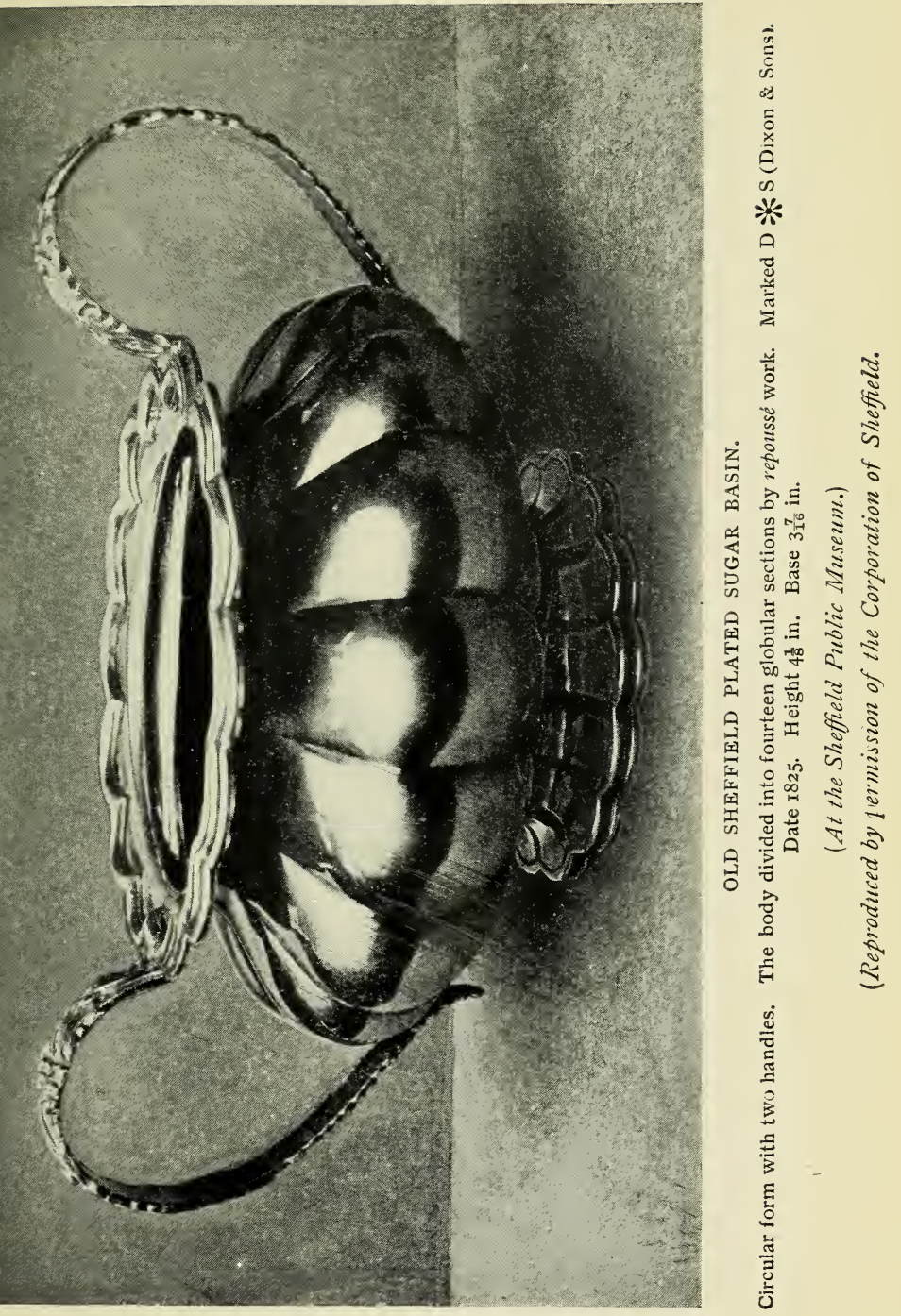

Crespell, the London makers, produced examples in the Adam style. Some of the silversmiths' work is pierced sheet silver, so that in regard to comparison with Sheffield there is in appearance not much to choose.

These basins were a later luxury of a more effeminate age. In I7II, according to the Spectator, in a "celebrated Coffee House near the Temple" an elderly ill-dressed man " called for a Dish of Tea, but as several Gentlemen of the Room wanted other things, the Boys of the House did not think themselves at leisure to mind him. ... At last one of the Rascals presented him with some stale Tea in a broken Dish, accompanied with a Plate of Brown Sugar." We are not concerned with the rest of the story, how the old stranger found his son in the well dressed habitue of the House, and exclaimed " Hark you, sirrah, I'll pay off your extravagant Bills once more, but will take Effectual care for the Future that your Prodigality shall not spirit up a parcel of Rascals to insult your Father." But we are interested in the "stale Tea in a broken Dish," and the "Plate of Brown Sugar" excites our curiosity inasmuch as it comes as a surprise to learn that other sugar was then in use; possibly it was candied on strings as we remember it in our boyhood at the table of an old-fashioned prelate and recluse. But centrifugally whitened and crystallized sugar it cannot have been, for that belongs to days within memory. 


\section{CHATS ON OLD SHEFFIELD PLATE}

A later example of sugar basin with melonshaped body is in date about I825 and its bold handles are finely ornamented. The rim and the foot have a pleasing contour following the fourteen sections of the repoussé body (illustrated, p. 2I3). It was made by Dixon and Sons, and the mark is a star with the letters $\mathrm{D}$ and $\mathrm{S}$ on each side. 


\section{VII}

\section{SOUP TUREENS}

\section{HOT WATER JUGS}

THE MARKS OF THE MAKERS

THE SUPPER TABLE 



\section{CHAPTER VII}

Soup tureens - Hot water jugs - The marks of the makers-The supper table.

THERE has been a recent dispersal of many fine collections of old silver plate, much of which consisted of glorious examples of periods which could and would only be used on state occasion at the dinner table. However much the possessor of old plate may love his family heirlooms, there is a hesitancy in actually bringing into use even in rare circumstances old plate of the Stuart period. Even though he may not be a connoisseur he might prefer some of his second-best silver for common use especially in days when people of high and low degree have often come very near to dining with Duke Humphry. It would therefore seem somewhat of a hollow mockery to bring out of the silver closet fine Queen Anne or early Georgian services with provender as bare almost as the larder of the Count Federigo degli Alberighi in Tennyson's "Falcon," in which story is told how that " noble bird" came to be served up as a meal for the lady Giovanna. Hence silver plate that is not used has been deemed a luxury to 219 


\section{CHATS ON OLD SHEFFIELD PLATE}

be sold under the hammer, and another race of owners will treasure old silver though it may not have come down from their ancestors.

The Soup Tureen.-That prologue to the banquet heralded and brought in with ceremony, from whose uncovered urn issues forth the incense to the feast, from which savoury and warming nectar, compounded of rare ingredients and rich essences, is dealt forth to titillate the palate, that forerunner of entrées and roasts, of baked meats and dainty sweets, marks the status of the chefit is at this point that one determines whether or not he is a true cordon bleu. Hence the trappings of so great a caldron must fit the occasion. The soup tureen that is insignificant is a cruse that promiseth no oil. It betokeneth poverty of invention and it might better be an earthern crock which fortune might mayhap endow with golden contents.

Perhaps the silversmiths have imagined all this or carried on a train of thought resulting in producing soup tureens of fine design and imposing character, and Sheffield has followed with her replicas and as the needle follows the pole.

We must look to Paul Lamerie, to Peter Archambo in the early period and Paul Storr at the end of the century for silver prototypes.

The Sheffield plated Soup Tureen illustrated (p. 22I) with tray is typical of the fine stability of design which came as an inheritance from the Queen Anne period, soberness and reticence with- 

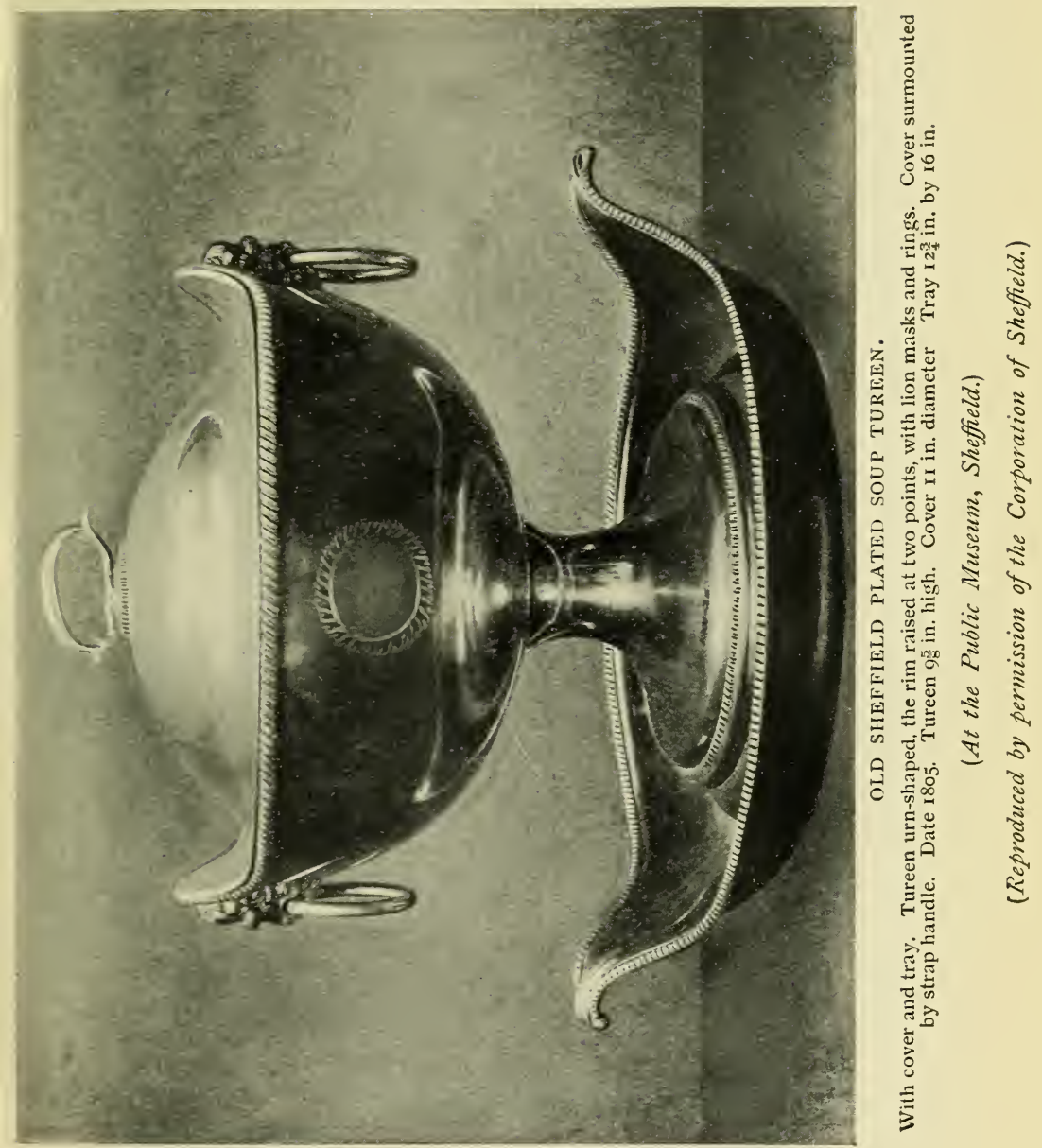

out that added touch of classic austerity which brought Greece and Rome to the English dinner table, and scattered the gods of Olympus throughout Staffordshire. The rim of the vessel is raised at two points, as is the tray. The godroon ornament is quietly sufficient to sustain the dignity of the design. The lion and mask handles complete a fine piece of restraint in composition. When this made its appearance at table depend upon it it was followed by sound cuisine, and the port of mine host was well chosen and from the right bin.

The Tureen illustrated (p. 225) is of the year of Waterloo. It is oval and stands on scroll feet, and the beautiful graduated form of the lid is especially noticeable. The rim is richly, though not too lavishly, decorated for so fine a piece. The upper portion of the cover springs in domelike fluted conformation and is surmounted by a handle with floriated base. The handles, a strong feature in well designed tureens, are practical, as are other portions of the ornament cleverly executed in die work.

Another Soup Tureen illustrated (p. 225) is of oval form with massive handles suggesting those of an urn. It carries its heavy decoration well, but the base is too rococo with its swirling curves. This example has a pierced heater with spirit lamp in centre. This is in date 1825 , when Canning " called the New World into existence to redress the balance of the Old." 


\section{CHATS ON OLD SHEFFIELD PLATE}

An interesting Tureen exhibiting the restlessness of motifs and the travail of the artist in his search for new designs is exemplified in the specimen illustrated (p. 229) where an excellence of technique is at once apparent. There is a beauty and a grace in the cover with its delicate incised chain ornament, its repoussé floral design and the striking godroon edge. The cover is surmounted by a ball on a leaf base. On the body the raised design, especially with the fruit and foliage, resembles that found on posset pots of the seventeenth century, but it is marred by an unfortunate leaf in the centre with a rib so prominent as to suggest casting. This is an undoubted blemish in ornament as the eye cannot leave this spot. But a bold attempt to win originality is shown in the legs and feet, which are of a curious and striking floral design, boldly rococo and somewhat Italianate in character; at first glance one expects to find them to be cherubs.

Entrée Dishes are always, when at their best, ripe with well-conceived and well-balanced ornament. The illustration (p. 233) shows a specimen, one of a set of four, with delightful design. The richly ornamented rims and the finely considered balance in regard to the double-tier effect make this especially acceptable. The cover has a finely ribbed effect which catches the play of light and displays its full effect and the ribs are so unobtrusive as almost to escape notice, but the full bodied effect is carried out to perfection. 


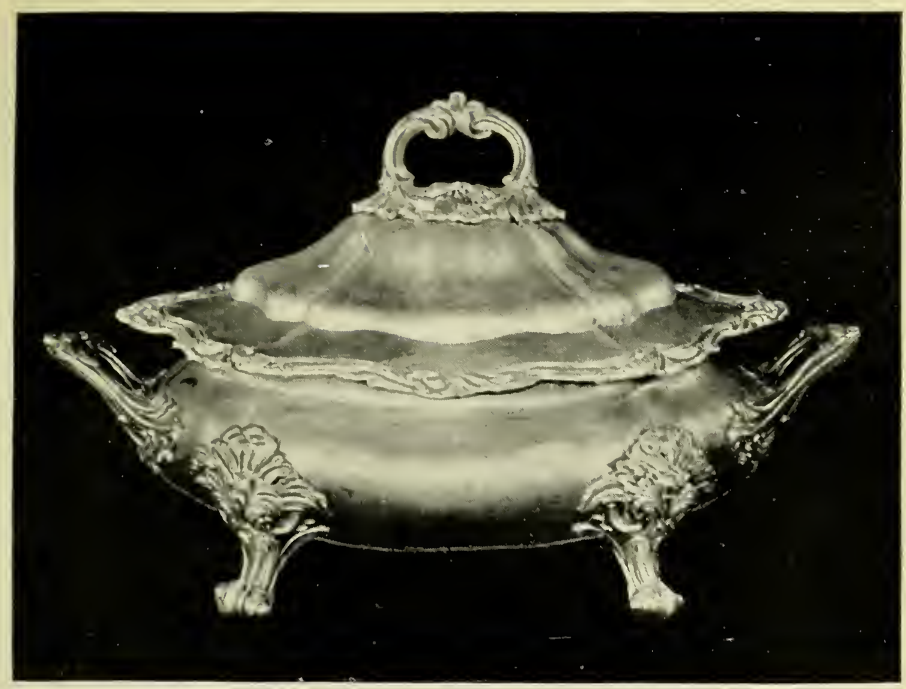

OLI) SHEFFIELD PLATED SOUP TUREEN.

Richly ormamented with scroll ornament. Date 1815 .

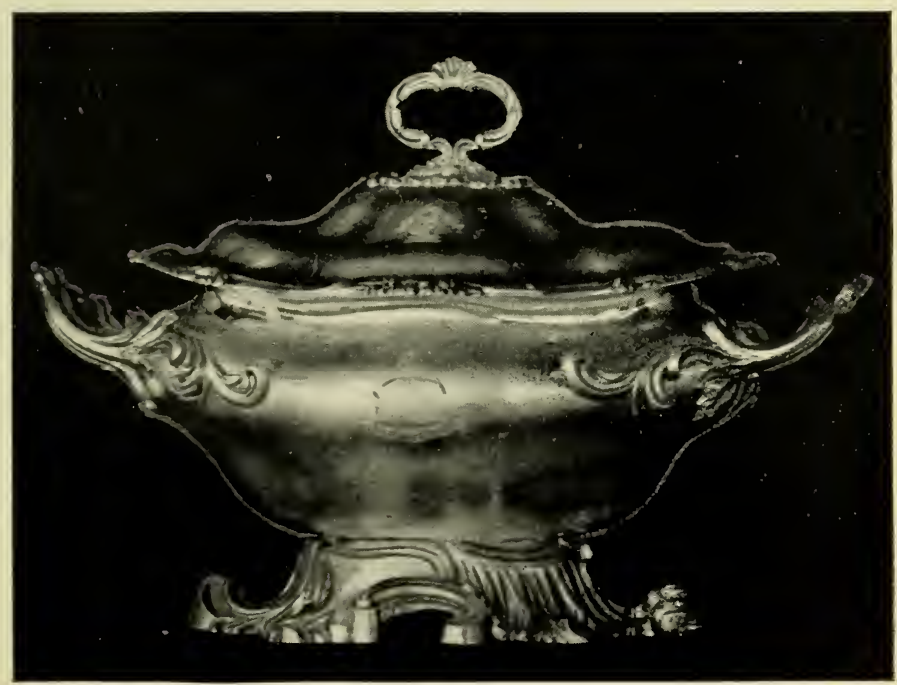

OLD SHEFFIELD PLATED SOUP TUREEN.

Rococo scroll ornament, pierced heater, with spirit lamp in centre. Date $\mathbf{1 8 2 5 .}$

(By courtesy of Walter H. Willson, Esq.) 

Another example of a later date, 1825, stands on its fine perforated ornament in the body. The feet are somewhat close together, and are made to appear more so by the dome-like cover swelling almost pear-shaped to an apex decorated by a cone. It is an unusual form, and free, notwithstanding its idiosyncrasies, from the glaring evils of elaborate and feeble decoration found at a slightly later date which impoverished design for the next thirty years.

Hot Water Jugs. - The form of the jug offers endless possibilities to the artist who designs practical shapes that the metal worker, the glassblower, or the potter can bring into being, each according to his technique. It is the duty of the artist, if he be practical as well as ideal, to offer only such designs as can be easily worked in the particular craft for which he is drawing his designs. In regard to narrow-necked vessels there is the suggestion that they are more suited to the potter than to the metal worker. In the East, where metal workers carry on traditions that go back long ages, we do not find that widemouthed vessels claim preference. It is not so much that the craftsmen are conservative and do not seek new forms, but rather that, having mastered their technique, they confine themselves to its limitations recognized centuries ago. There is no doubt that the narrow-necked jar in the old fable of the Fox and the Crane was one made by the potter. The difficulties in technique in manipu- 


\section{CHATS ON OLD SHEFFIELD PLATE}

lating a jug such as is illustrated (p. 235) must have been great, though not insuperable.

But the fine Adam jug, with this premiss as to narrow vessels in general, offers a superlative example of the Adam style executed as early as I770 (illustrated, p. 235). The square base with ball feet, the simple festoon of drapery, encircling rosettes but not being supported by them, the band of ribbed ornament placed just at that position where it attains the maximum effect, the fine exquisitely balanced proportions of the neck as natural and wonderful as nature in graceful birds such as the swan, and the pleasing lines in the curve of the spout-all these points are points of beauty impossible to describe in words, but quick to strike the trained eye satiated with improper ornament and feverishly awaiting the advent of pure unalloyed beauty of form. One never grows weary of contemplating such a perfect example as this of the art of the modern metal worker, that is modern since the old days of Greece and Rome, and modern as in comparison with the outburst of the great Italian Renaissance.

Two other hot water jugs are illustrated (p. 229) each typifying forms into which the metal worker converted his sheet silver. That on the left is severe in form. It represents the spirit of classicism cold and unsatisfying. The absence of the curve in the body and the straight lines at the shoulder might have proved, had Hogarth seen it, some of his points as to the line of beauty. 


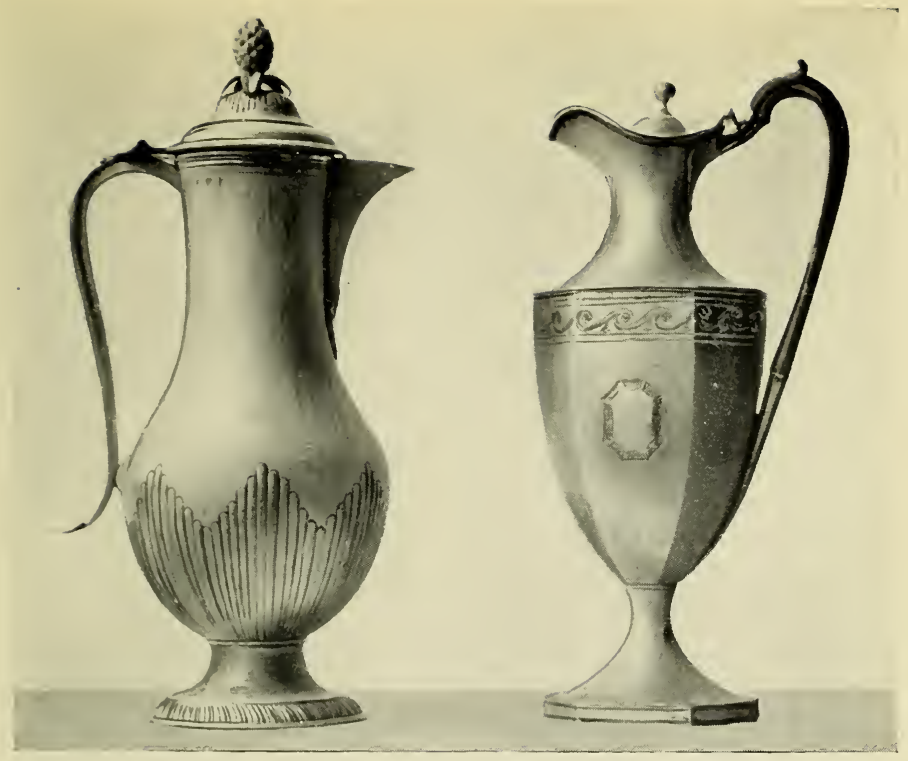

OLD SHEFFIELD PLATED HOT WATER JUGS.

Circular base : lower part of body decor- Urn-shaped body on octagonal foot. ated with star fluting. Cover sur- Classic ornament. Silver shield. mounted by pineapple. Dated 1775 .

Classic ornament. Silver shield.
Dite I795.

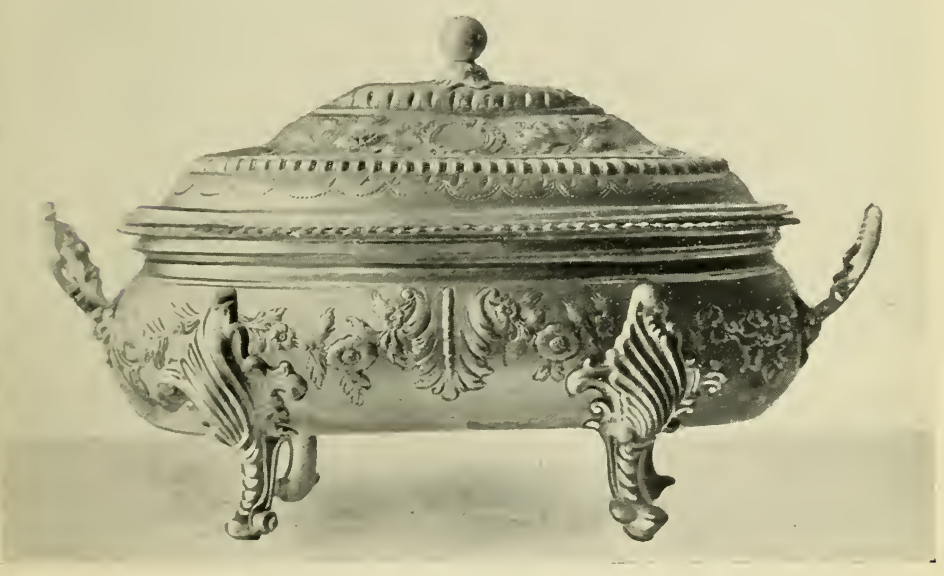

OLD SHEFFIELD PLATED TUREEN.

With foral repoussé decoration and four spirally fluted scroll legs. Cover richly chased and gadrooned, surmounted by ball. Date 1815 .

(In the collection of B. B. Harrison, Esq.) 

The plane surfaces are too few to be attractive, to increase their number would be to depart from a simplicity of outline at which the artist-designer has aimed. The elongated handle striking a, sharp acute angle adjacent to the edge of the broad facetted body offers a inharmonious note The space between the handle and the body is not a pleasing space to the eye. In technique the jug is perfect, as perfect as the silversmiths could fashion it, and as representative a replica as Sheffield could turn out. The eye wanders to the upper portion and finds restfulness, and it is this upper portion which makes the jug lovable and beautiful.

Its fellow on the same page affects a new form. Its handle carries one back to the porringer of Stuart days with its out-turned terminal. The body swells with beautiful symmetrical curves. Its plain cold effect is relieved by the broken flutings carried part of the way up. The spout again is reminiscent of the earlier forms in the flagon of bye-gone days. The cover has a delightful pineapple ornament of sufficient size to give character to the piece. Although composite in its conception it takes its place on a plane indubitably its own.

The Marks of Makers.-Having extolled the object made, it would be delightful to be able to extol the maker. But the records of the copyist platers of Sheffield are not in such an exact state as to determine this. Even when certain initials 


\section{CHATS ON OLD SHEFFIELD PLATE}

and marks identify a particular firm, and one has run it to earth, one is confronted with the proposition as to who did actually make the piece. At what particular part of the chain, leaving out the drawers of the ingot from the charcoal fire and the mechanical rollers, was it fashioned by the man whom we wish to admire. Names of firms we know are hall marks as to quality. In silver formerly the maker did make the piece to which he was proud to stamp his initials, but even then the law conspired to cheat him of the guerdon of posterity's worship. The initials of Christian name and surname that is sensible enough. We all are aware of that abbreviation, and of accredited signs, from E.R., Elizabeth Regina, to the butterfly of Whistler. But disguised under the first two letters of his surname the silversmith in 1697 , by William III, $8 \&$ 9, cap. 8, left little evidence of his personality. William Keith becomes KE and Robert Cooper is CO, and Seth Lotfhouse is L.O. In I739 by George II, I2, cap. 26, just before the Sheffield period, the first two initial letters of Christian name and surname became compulsory. So that there is every reason why at Sheffield, the workmen who executed the mouldings and the craftsmen who pierced the design or chased it, should have added their iritials. The die sinker might go by the board, but the artisan who with the highest art concealed art with his die work and his wire, he too might place his sign. There are 


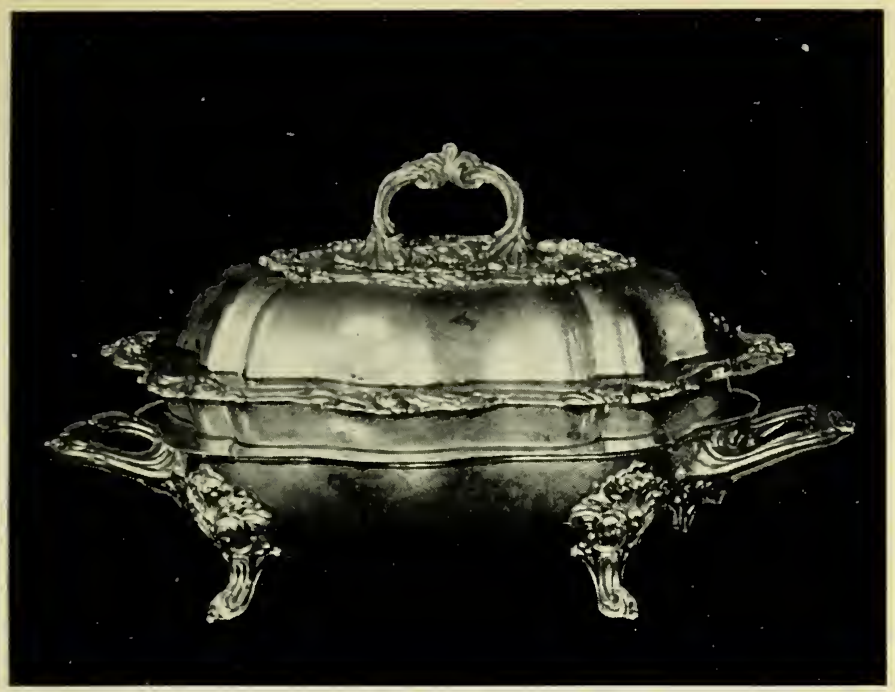

OLD SHEFFIELD PLATED ENTRÉE DISII.

One of four, with heavy ornament of scroll design. Date i815

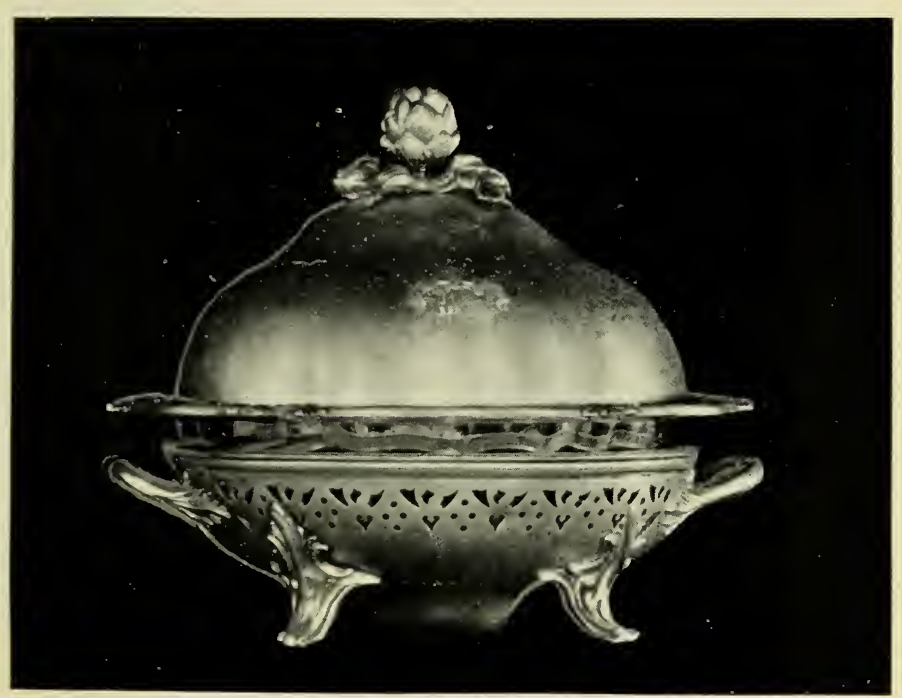

OLD SHEFFIELD PLATED ENTRÉE DISH.

With bulbous cover surmounted by rose. Date 1825 .

(By courtesy of Walter H. Willson, Esq.) 



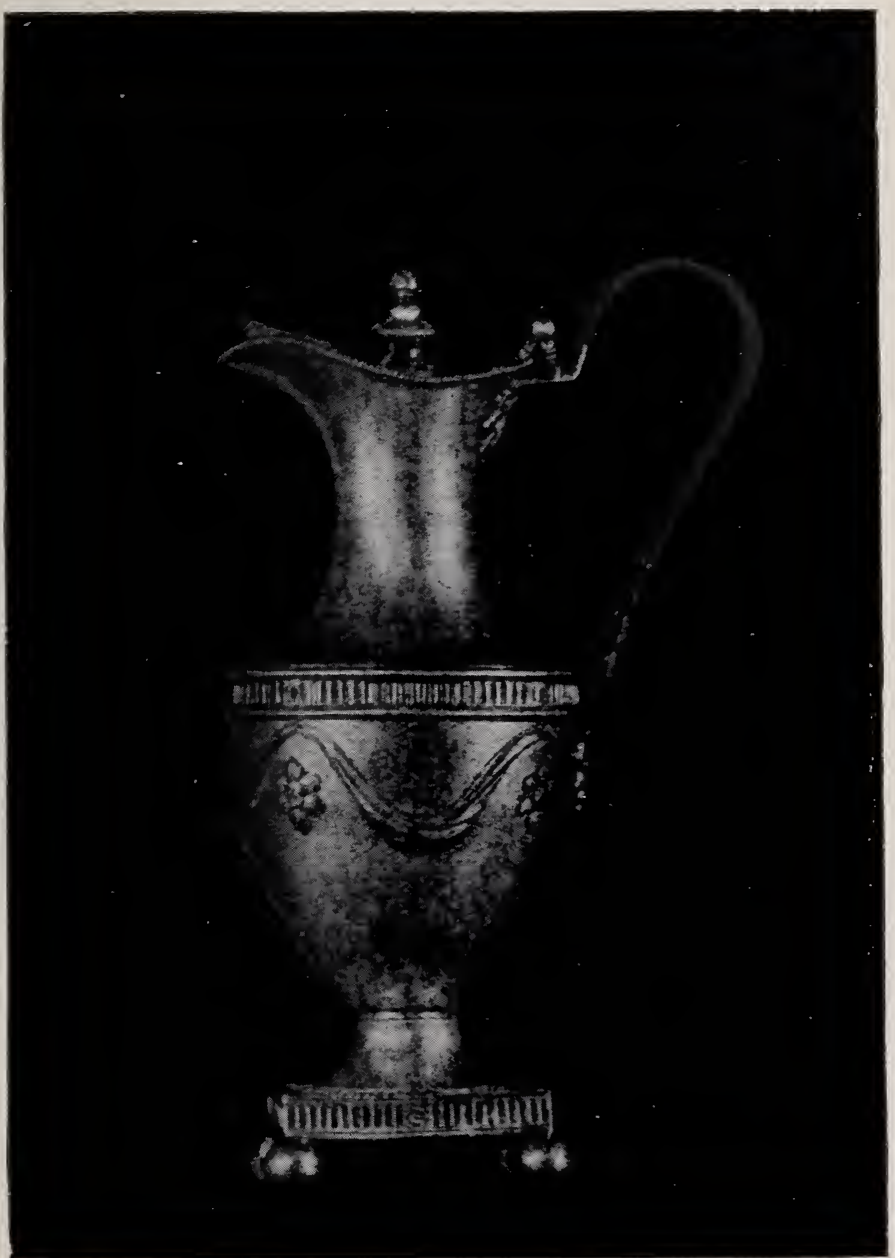

OLD SHEFFIELD PLATED HOT WATER JUG.

Urn-shaped, on base with claw feet. Rosette decoration carried out in base and body, together with festoons. Shoulder and base ornamented with band of vertical fluting. This example typifies the Adam style at its best. Date I770.

$$
\text { (By courtesy of Walter H. Willson, Esq.) }
$$



workmen's marks, but nowadays they mean nothing except that they are " workmen's marks." On Worcester porcelain it is the same, certain symbols are believed to be workmen's marks. That is all. The French were wiser. At Sèvres the marks of each painter, decorator, and gilder of the porcelain from I753 to I80o is duly recorded. A crescent denoted that Ledoux painted the birds, LG tells that Le Guay did the gilding, a pair of compasses show that Mutel painted the landscapes, LR stands for La Roche and his medallions and emblems, $F$ is Falot for butterflies, and so on. There are over a hundred and twenty known workmen's marks. And in I750 the French cabinetmakers stamped their names on their works.

That certain workmen's marks did appear on the old Sheffield plate indicate pride of work of execution. But specialization should not have stamped out personality to the extent that it apparently did. Even names of firms are forgotten and initials of producers are not always readily traceable. There is much research needed in regard to old Sheffield plate. Much has already been done. But the idolatry of the Sheffield replica standing as it does on its perfect technique, should be carried back a stage. We have said nothing of the artist designer and draughtsman who carefully, with skilled pencil, worked out the drawings to be carried out by the craftsmen. $\mathrm{He}$ it was who stood between the silver plate 


\section{CHATS ON OLD SHEFFIELD PLATE}

prototype and the silver plated translation. The admiration should be extended to the original makers of the models. A scientific classification of old Sheffield plate should set out to identify what particular makers and designers of silver plate were copied by the silver platers of Sheffield and elsewhere. A collection of Sheffield plate without the knowledge as to the fount from which it came is like a collection of interpretative engravings from old masters' paintings with the old painters' names omitted.

The Supper Table.-In an age when a considerable amount of inventiveness was displayed in regard to economical forms of furniture, such as folding tables, library steps which shut up, dressing tables with wings that pulled forward, telescopic dining tables were invented and patented in 1830 by Richard Gillow, and nests of drawers arranged as though space were as great a desideratum as it is in a modern flat, it is not surprising to find that the metal workers at Sheffield came into line with the fashion for neat and ingenious contrivances for the table. A special feature was made of small delicate fitted appurtenances for the card room and the supper table. Collapsible toast racks were made about I825 to I830 standing on four ball and claw feet, by a firm stamping its name as R.C. \& Co. Tinder-boxes with candlesticks were cunningly contrived. Reading shades came into being with circular green silk guards, capable of being raised and lowered and manipu- 


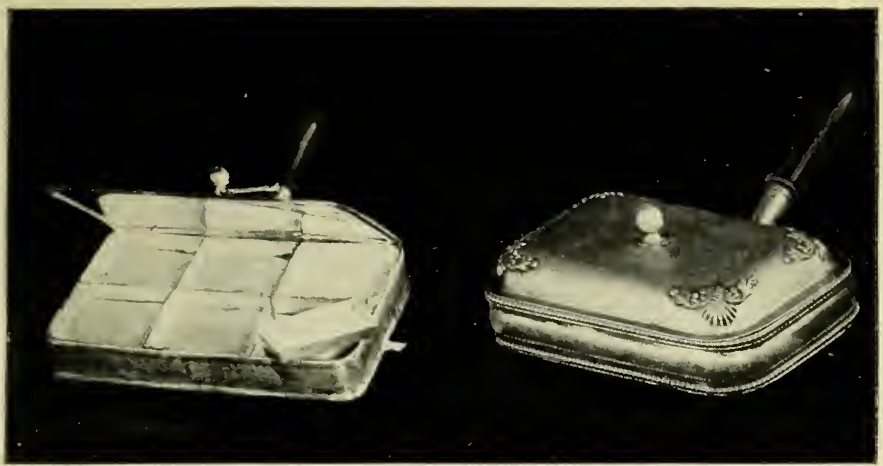

OLD SHEFFIELD PLATED TOASTED CHEESE DISHES.

Showing interior with six compartments. Date I800.

Showing exterior : cover with ornament. Date 1810.

(By courtesy of Walter $H$. Willson, Esq.)

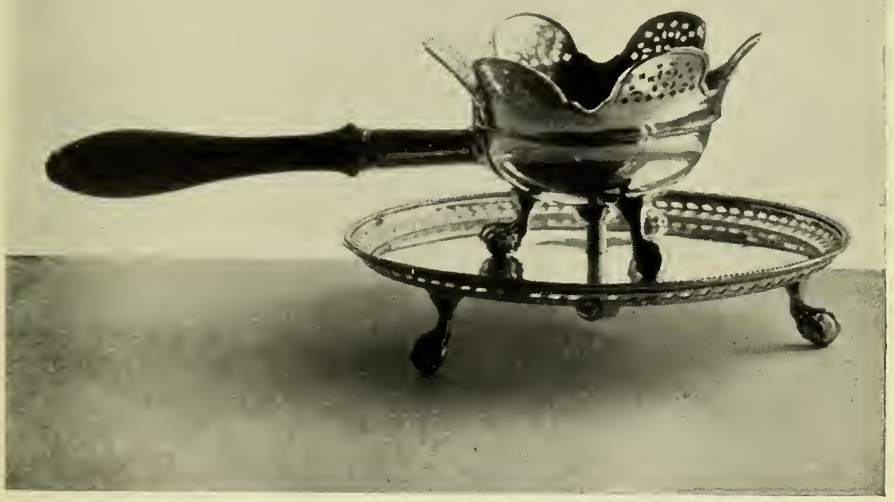

OI.D SHEFFIELD PLATED PIPE I.IGHTER.

With pierced escalloped top, wooden handle, and on tray with pierced rim on claw and ball feet. Date 1783 .

(In the collection of B. B. Harrison, Esq.) 

lated in a variety of positions. Many of these articles only achieved a momentary success. But among those remaining are certain supper dishes for serving cheese. In the example illustrated (p. 239) it is seen that it has six compartments for toasted cheese to be served hot and kept hot. These cheese dishes are uncommon. The handle is wood. In date this is about $\mathrm{I} 800$, the adjacent example is about I8Io and has applied shell and foliage at the corners of the cover, and a similar wooden handle.

A fine specimen of a little known article of former use is illustrated on the same page. It is a Pipe Lighter, with pierced and escalloped edge. It has three ball and claw feet. It stands on a circular tray finely pierced having ball and claw feet. It might at first glance suggest to the collector that it was Dutch in origin, and suggests some form of charcoal brazier, but it is indubitably a remarkable specimen of old Sheffield plated work in date about 1783 . 



\section{VIII}

\section{CENTREPIECES}

\section{THE CENTREPIECE}

THE DESTRUCTION OF OLD DIES

THE MELTING DOWN OF MASSIVE SHEFFIELD PLATE

THE PASSING OF THE DINNER TABLE 



\section{CHAPTER VIII \\ CENTREPIECES}

The centrepiece-The destruction of old dies-The melting down of massive Sheffield plate-The passing of the dinner table.

THE centrepiece was the pièce de résistance; it made an imposing feature with its fruit which was to be served at dessert; it has developed later into an object for floral decoration standing as a monument of colour on the table, and was in more modern usage combined with lights when the old candelabra were considered to be out of date, and before the modern electric candelabrum made its appearance. Accordingly, we find massive decoration and strong bold design in most of these centrepieces. The Frontispiece illustrates an especially fine example with ten baskets of glass and the twisted branches are constructed to give the massive piece a lightness and a grace, although it was necessary to have a certain solidity to carry its heaped-up delicacies. There is a fine balance in this example and it is typical of the openwork centrepiece as distinct from a more massive form introduced when an ambitious bid 


\section{CHATS ON OLD SHEFFIELD PLATE}

made by Sheffield for recognition in carrying out the modelled figures and other elaborate structures which became so prevalent in the first thirty years of the nineteenth century.

Another example produced in wire work in early manner, in date about I790, is illustrated (p. 247). This is on four ball feet and has a large basket at the top, vase-like in form, with handles. From the standard supported by three C-shaped branches are suspended four smaller baskets. Its lightness and flexibility of design are its noticeable features and there is a practicability too in the form as the small baskets with handles can be readily removed from the branches on which they hang.

A massive centrepiece with stand on four richly moulded feet in French style is ornamented by heavily gadrooned architectural ornament. This supports three semi-nude female figures who form a column which is surmounted by a large urn-shaped basket ornamented with interlaced bands and floral pierced work. A heavy glass bowl of cut glass with serrated rim and facetted ribs completes a grandiose piece representative of the period about I825. (Illustrated, p. 25I).

Other forms are found with peculiarities of design which win acclamation, though on the whole there is always in comparison with the silversmiths' art of a century earlier something undesirable, not so much as to what is lacking but what has been added. There is a departure 


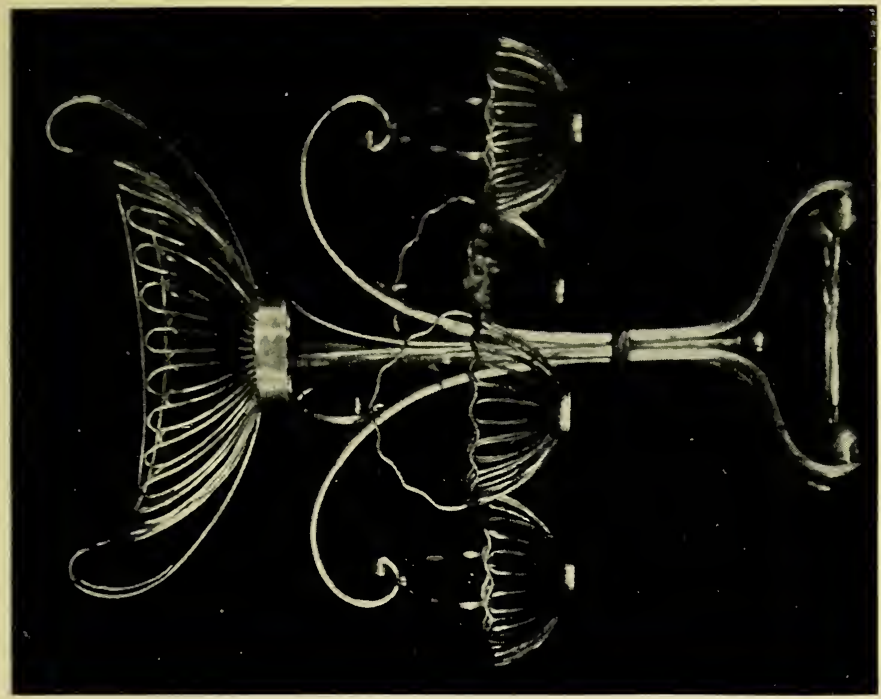

望洔

종

일

ปิ

हैं⿰⿺⿻一𠃋十

\& $\Xi$

气

ฮี

눟표

3 हेच

ํㅡㄹ

ํํㄹ 先

ह气 क्ष

$\dot{0}+\frac{\pi}{5}$

종

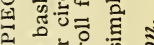

क षे के

국ㅎㅀ

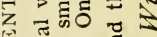

ธิ ठั

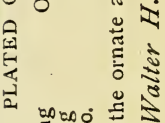

की

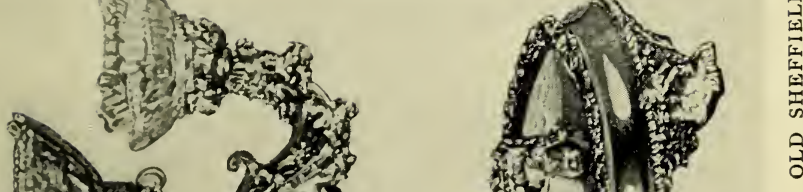

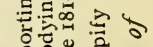

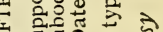

क्ष हु कू के

究苛苛 ह

A ह 류

०

व०त 3

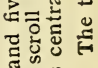

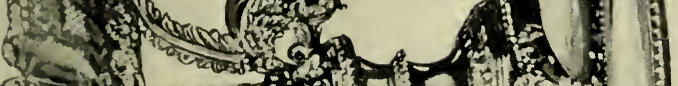

क

牙密 क

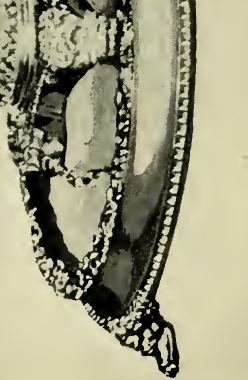

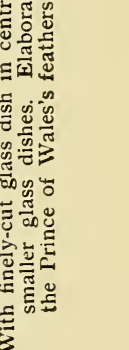



from soberness and an attempt to give ornament a place whether ornament is necessary or not. This effort to be ultra-artistic more often than not over-reached itself and the results do not give the same æsthetic pleasure as those of earlier designers who know the golden rule in art-what to omit. But comparisons are odious. We take representative examples of a period and continue the study and give them the respect due, and when one finds an oasis in a desert of meretricious art one is profoundly thankful.

The Centrepiece illustrated (p. 247) offers many points of attractiveness. It attempts magnificence and almost achieves it. The employment of three ostrich feathers in the design suggests at once the period of George IV. It has been employed in minor pieces by the silversmith as it was successfully used by Hepplewhite in his carved mahogany chair-backs. This is not the only example known with similar feather decoration so prominently featuring in the design. There is another example with outstretched plain branches having four cups so far removed from the central standard as to suggest gas-globes. The feathers by this arrangement are given an undue prominence and lose the graceful effect they have in the example here illustrated, where the curved branches with rich scroll ornament harmonize with the more prominent central support for the cut glass dish. The branches support four smalle $\mathrm{r}$ cut glass dishes of really fine character. This cut glass work is 


\section{CHATS ON OLD SHEFFIELD PLATE}

of the most beautiful character and adds greatly to the grandeur of the piece.

As indicating the return of the Sheffield workers to designs prior to their own day the Chestnut Dish and Cover illustrated (p. 255) offers conclusive proof. It has all the quietude of the work produced in the Queen Anne period. It depends for its effect on its form and the play of light on its surface. The twisted handles are terminated by lion masks. The foot is plain, but the edge of the rim of the body is quietly godrooned. The lid is surmounted by an oval knob, which the Staffordshire potters seized later as their own. The accompanying illustration shows a Fruit Basket, in date about I8Io, and it resembles the work of Paul Storr, the London maker of that period. It is of simple basket form. Its broad rim emulates the technique of the basket maker in appearance and is equally necessary here in order to add to the strength of a design carried out in wire. The base is oval and stands on four claw feet in combination with scroll design as shown in other examples in candelabra and other work of the same period.

The Destruction of Old Dies.-The Sheffield firms were not wise in their generation. They committed a great blunder which they regretted for long afterwards. We do not say that this led to the extinction of the industry, for there were other very important causes which resulted in silver plating in the old style being superseded. 


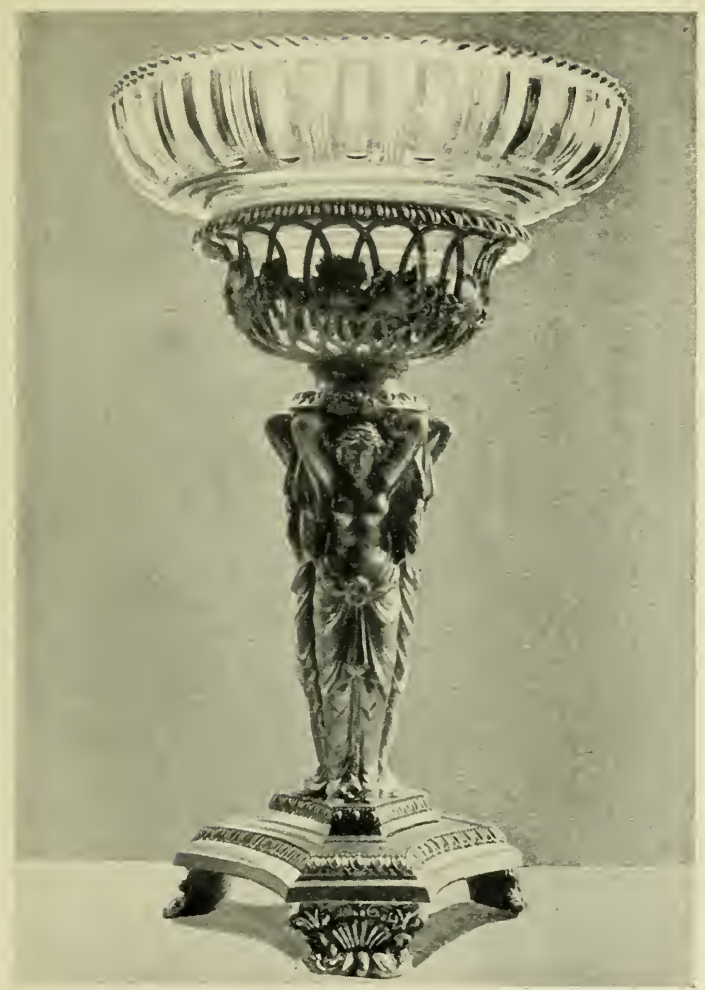

OLD SHEFFIELD PLATED CENTREPIECE.

Hexagonal base on scroll feet. Urn-shaped wire basket, supported by three semi-nude female figures, surmounted by large circular cut-glass bowl.

(In the collection of B. B. Harrison, Esq.) 

But undoubtedly the destruction of old dies by a number of firms did lead to the constant production of work which might very well have been left undone. When the fashion for the classic designs of the Adam period and that immediately succeeding it was found to have been discarded, these old dies were melted down for the value of the metal. They represented many thousands of pounds outlay to each of the firms who had produced them, and nowadays, when reticence and sobriety of design have again come into their own after the long night of the early and later Victorian meaningless trivialities in design in metal work, these old dies would have won distinction by their re-employment. But they must remain a sad memory to those who know what once has been, and as so often happens in any industry dependent on the caprice of fashion, it is easy to be wise after the event.

\section{The Melting Down of Massive Sheffield} Plate.-Yet another deplorable misfortune overtook Sheffield plate. It was found that the copper in some of the old examples was valuable. Prices of copper had risen, and on the other hand silver had fallen. Certain enterprising firms dealing in metals began to collect all the old Sheffield plated examples they could lay hands on, and they ruthlessly melted them down. Quite considerable sums of money were made in this manner, and very few fine pieces were rescued from destruction. Though we heard of one instance of a dealer 


\section{CHATS ON OLD SHEFFIELD PLATE}

who was artistic enough to select certain examples that he liked for their beauty, and his family have them to this day. We hope his taste was sound. But the result was to aim a blow at collecting Sheffield plate, and to create many a hiatus which collectors find to their chagrin to-day.

The Passing of the Dinner Table.-With all due respect to modernity there is in middleclass households still to be observed an absence of taste in silver. There is silver present and enough of it. But not sufficient care has been paid to studying the fine forms and the exquisite creations of former generations of English silversmiths. Now and again great surprise is expressed at big prices realized at Christie's or elsewhere for fine specimens of plate. But as to the general education relating to the art of the silversmith and the really beautiful designs that have come down for hundreds of years as ornaments to the dinner table the average city merchant and the average man of affairs has surprisingly little knowledge. When he steps out of his own world into that of art he stumbles blindly and often wilfully. His pictures please him and he is often boastful concerning thembut there are others who know different.

Perhaps nowadays the hotel and restaurant habit has contributed not a little to disturbing the pride that the Englishman took in his own table. A hundred years ago, and right down to 


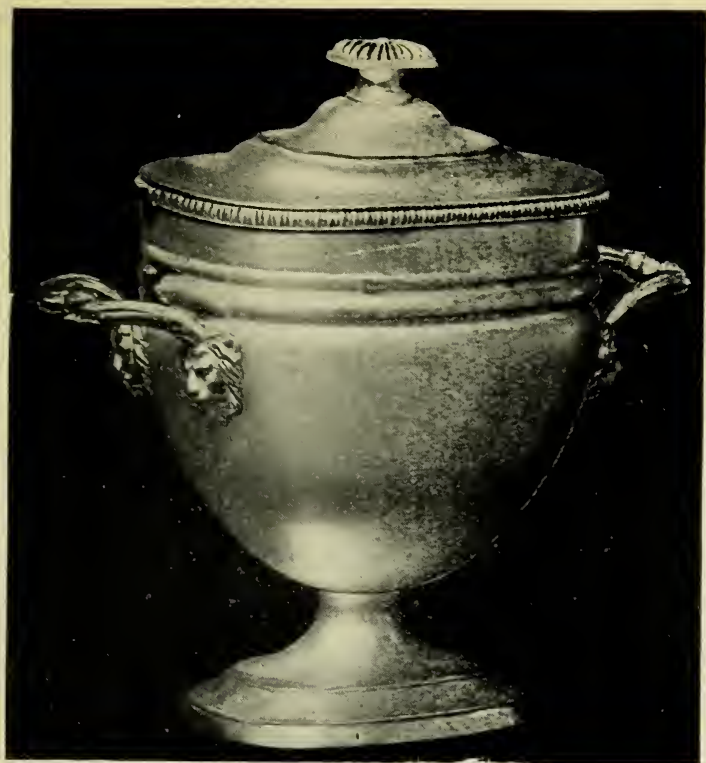

OLD SHEFFIELD PLATED CHESTNUT DISH.

Plain design in Queen Anne style : silver gadrooned edges : lion mask handles, Date 1810

(In the collection of B. B. Harrison, Esq.)

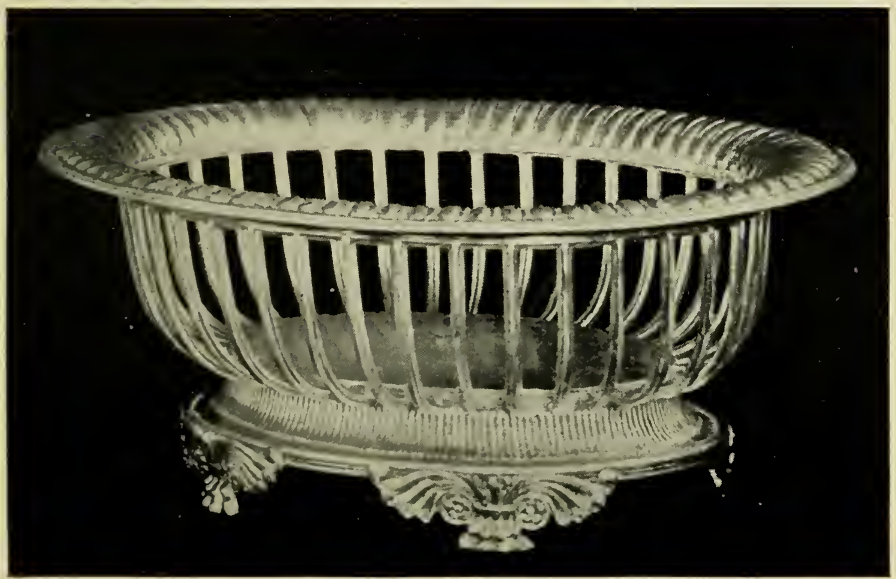

OLD SHEFFIELD PLATED FRUIT BASKET.

In fluted oval base, with four scroll feet. Wire work design; broxd gadrooned rim. Date 18 Io.

(By courtesy of Walter H. Willson, Esq.) 

the time immediately preceding our own - the days of Thackeray and Dickens-there was a keen regard by the host for the appointments of his table. He carefully laid down wine, he personally supervised his cellars and knew the temperature necessary to maintain the character of the contents of his bins. He was a connoisseur in wines; nowadays he leaves that sort of thing to his wine-merchant. He kept an eye, too, on the plate closet, and knew to a nicety what particular services and what special vessels fitted functions over which he presided. Perhaps life has become more complex for him to-day, possibly he now pays more attention to his golf clubs and his motor-car. He has more extraneous pleasures, and after all modernity has its claims on his time. He may suffer less from gout than did his sires. But as a giver of a feast, as a host with inner knowledge, as a man sensitive for the palates of his guests, the modern host is not the same host as was his grandfather. 



\section{IX}

\section{CLOSE PLATING}

\section{ClOSE PLATING}

THE BUCKLE MAKERS

GERMAN SILVER AND OTHER WHITE METALS

THE FACTORY SYSTEM

THE END OF THE STORY 



\section{CHAPTER IX \\ CLOSE PLATING}

Close plating-The buckle makers-German silver and other white metals-The factory system-The end of the story.

APART from the process of covering baser metals with silver by fusion and preparing sheets of copper superimposed with silver by rolling, there was the earlier process always designated as French plating. As we have shown, the plating of baser metals was nothing new, but the Sheffield process was a new invention which had farreaching results. About the year 1800 a great many small articles in common use were manufactured by a method known as close plating. Knives, snuffers, skewers, buckles, spurs and harness were subjected to this means of silver plating. A great many of these articles have the name of the maker stamped upon them. Fruit knives, table spoons and forks, fish knives, sugar tongs, and in fact all small articles which it was easier to make in this manner than manipulate from the silver plated sheet. Iron skewers were so plated with silver and 


\section{CHATS ON OLD SHEFFIELD PLATE}

steel blades of knives. An iron skewer made in Ireland is marked "Sly. Dublin," and the marks of the makers of the close plated work are as difficult to trace and identify as some of the others in the process of plating by fusion. Horday \& Co. is found on some late examples, and the fleur-de-lys is another mark frequently seen. The close plating process seems to have been followed both at Birmingham and Sheffield from about I795, and was subsequently employed in London. The base for close plating was mainly iron or steel. Instead of resorting to the longer and more expensive mechanical process of fusion and rolling, the article intended to be plated with silver was covered with a thin sheet of silver and while hot it was burnished down to the core of the baser metal, by means of a compound of lead and tin, which, employed at a low temperature, did not lessen the temper of the article thus plated.

It is to be observed, however, that the permanency of close plated articles cannot be compared with those produced under the rolling process. Whatever may be the reason there seems to be a weakness in the technique, for it is found that they are strongly affected by exposure to damp or extreme heat.

The Buckle Makers.-It has been asserted that Boulsover made buckles; this is unlikely. The trade had mainly settled in Birmingham and Wolverhampton, and there was an extensive trade carried on in London. The fashion of the 
buckle underwent many vicissitudes in fortune. The Puritans adopted shoe strings. It was in Stuart days that Herrick sang of his mistress :
A careless shoe string, in whose tie
I see a wild civility.

Silk laces with silver fringes and tags were in fashion on the eve of the Restoration, although the common folk confined themselves to leather laces.

All through the eighteenth century the buckle was worn. Sometimes, happily for the buckle makers, the fashions grew so extravagant that the ladies wore such large square buckles either of silver or silver plated as almost to conceal their feet. Towards the end of the century fashion deserted the buckle makers and they were in a parlous state. It was natural that they termed the dispiacement " the most ridiculous of all ridiculous fashions the effeminate shoe string." Birmingham, Walsall and Wolverhampton employed no less than twenty thousand workers in the buckle industry, and they could ill afford to be flouted by the fickle jade Fashion.

In 1792 the buckle makers of the provinces determined to enlist the sympathies of the First Gentleman in Europe on their behalf. They were introduced to the Prince of Wales by Sheridan. They represented that although the interest of the button manufacture had enlisted parliamentary assistance they had no redress against the shoe- 


\section{CHATS ON OLD SHEFFIELD PLATE}

string. They did not desire sumptuary penalties, but they claimed the personal support of His Royal Highness to obviate the stagnation of trade causing "miseries, emigrations and other horrible consequences."

The buckle makers' petition runs as follows:

"We beg leave to observe, that when Fashion, instead of foreign or unprofitable ornaments, wears and consumes the manufactures of this country, she puts on a more engaging form, and becomes Patriotism. When Taste, at the same time and by the same means that she decorates the persons of the rich, clothes and fills the naked and hungry poor, she deserves a worthier appellation, and may be styled Humanity. We make no doubt but your Royal Highness will prefer the blessings of the starving manufacturer to the encomiums of the drawing-room. We know it is to no purpose to address Fashion herself; she is void of feeling, and deaf to argument; but, fortunately, she is subject to your control. She has been accustomed to listen to your voice, and obey your commands."

The Prince of Wales, followed by the Duke of York, ordered the discontinuance of the use of shoe-strings by members of his household.

The buckle makers of London and Westminster followed in the wake of their provincial brethren, by publishing an appeal to the public, complaining that, however mischievous the whim, however effeminate the appearance of shoe-strings, the 
wearing of them still increased, and hoping that henceforth no philanthropic friend to his country would, by following an evil example, virtually take part in snatching the bread out of the mouths of thousands of poor and industrious families. They also petitioned the King and Queen, the Prince of Wales, the Duke and Duchess of York, the Princess Royal, and her brothers Clarence and Gloucester, to aid them in their extremity. They unbosomed their cares to King George as a parent and protector whose soul was his people's. They assured Queen Charlotte that her disapproval of shoe-strings coming into her royal presence, would suffice to reinstate them in their former blessings; while they told the Princess that if she would but wear buckles, they should no longer remain monuments of silent grief, but commemorate with grateful peals of acclamation the annual return of the day which shone so propitious on their wants. Equally lavish of praise and prayer to the rest of the royal family, they reserved (for some unknown reason) the most extraordinary of their appeals for the Duke of York.

After informing him that " honour, dignity, and birth are like the landscape when the luminary is behind a cloud, without the rays of beneficence tinging each distinction with its inherent brightness," they remind him that ribbon, leather, and whipcord threaten to ruin a staple manufacture doing an incredible trade abroad, and humbly pray his Royal Highness to discourage shoe- 


\section{CHATS ON OLD SHEFFIELD PLATE}

strings " both militarily and domestically." Then they break out: "Conceive what immense numbers of persons have spent the prime of their youth and manhood ; entered into connections ; increased their families; and embarked their all, having this trade for a dependence. Their hearts bleeding at the cruel inconsiderate capriciousness of Fashion; difficulties and impossibilities rise in quick succession to defeat the probability of fixing on any other branch or occupation. The nuptial tie, pitiably relaxed by reiterated sorrows; the children cry louder and more vehemently for food; the husband unmanned; his wonted courage fails; the wife, more delicately sensible, is not able to resist one of the obtruding woes which crowd upon her mind. Few friends before! less than ever now! Demands come quickest upon the most needy, often reminded of their bereaved trade, and no philosopher's stone to smooth the creditor's brow! Now spread wide the happy cause, the prospect changes; Hope with cheering looks advances. A letter from the trade at large informs them of our appeal to your Royal Highness. Instantly they assemble, and congratulate each other they have so glorious a source of expectation! Hope, with magic power, appeased their hunger, removed their despondency, makes the manufacturer's heart dance with joy ; and the Duke and Duchess of York echoes in their cups, toast after toast. And your petitioners will ever pray." 
The result of all this was that buckles were unusually prevalent at the Queen's birthday drawing-room, held soon afterwards, when the beauty and brilliancy of the buckles worn by the Prince of Wales, the Duke of York, and the Earl of Fife attracted general notice and admiration. It was but a transient triumph : Royalty failed to control Fashion; and although exceedingly small buckles were occasionally seen down to I800, their fate was sealed, and by I8I2 the buckle was extinct.

German Silver and White Metals.-The early silver plating was on soft copper, but towards the end of the plating period, an alloy was made with brass in order to give the base a greater strength and possibly for reasons of economy. Later German silver was introduced as a base. It was hard. It was not altogether a success, possibly by reason of its greater cost. But it had the quality of forming a hard solid basis beneath the silver plate, and when the latter showed signs of wear the German silver, being of a light colour, did not come into undue prominence in betraying the wear and tear.

There is also tutenag, an obscure metal, an alloy of antimony and zinc which was known to the Chinese, though not much has been written concerning this alloy and its employment in this country for articles of artistic excellence. But candlesticks and fenders have been made of pleasing appearance and having good wearing qualities. Then there is the Britannia metal 


\section{CHATS ON OLD SHEFFIELD PLATE}

period where pewter and Britannia metal met. In fact, during the latter days of Sheffield plating there were many minor competitors offering substitutes for the silver plating at a lower price. Commercialism was in the air, and at the flood the old methods of plating by fusion were swept away.

The Factory System.-Looked at from all points of view the Sheffield plating industry betrayed the rise of the factory system, as did also the great Wedgwood and other Staffordshire firms. The factory system, by reason of its systemization, apportions set tasks to a chain of individuals, so that no one individual can be said to be an artistcraftsman in the same sense that he would have been in the old days. The old Italian masters compounded their own pigments and carved and gilded their own frames. Life was then more crystallized. The viciousness of the factory system was that it destroyed the personality of the craftsman. In latter days strong movements have been inaugurated to attempt to revive art industries where the artist craftsmen will not be obliterated under the name of a firm or a syndicate.

The End of the Story.-It has been shown throughout this volume that old Sheffield plate by reason of its artistic excellence, should be treasured and loved. Its fashioning is most certainly a lost art. The old methods have disappeared for ever. It would be impossible to procure workmen nowadays with the fine instinct shown by those under the old régime. 
If a return were made to the old process in lieu of the solid plate; if, let it be granted, that electro-plate were superseded by a freak of fashion which demanded Sheffield plate in the old manner, the operation would still be impossible. The cost of producing Sheffield plate by fusion and rolling would be greater than if it were solid silver. Hence collectors have realized the value, not only æsthetically but the actual value of a fine series of wonderful works of art produced in an artistic manner which can never come again. It has been collected by far seeing enthusiasts, and they have bought at prices which will never occur again. Recently at Christie's a set of four Adam style candlesticks brought thirty-two pounds. But this was not too much for so splendid a technique. And without doubt old Sheffield plate, especially in examples that are not forthcoming as having been made in silver plate, will command much higher prices in the future. English earthenware in some instances has eclipsed porcelain in regard to prices under the hammer, and engravings after paintings in oil finely executed in a masterly technique, never again to be equalled or attempted, have won a greater acclamation at auction than the originals. Technique is a factor and a great determining factor in collecting, and sound connoisseurship recognizes this. Old Sheffield plated ware in its finest period exhibits one of the most surprising techniques in metal work ever produced in this country. 



\section{APPENDIX}

I

EXAMPLES SHOWING

TYPES OF HALL MARKS

ON SILVER PLATE

Used by the various

Assay Offices in operation

during the Manufacture of

Sheffield Plated Ware

II

EXAMPLES OF MARKS

Found on old

Sheffield Plate

during the period

1753 to 1840 

EXAMPLES SHOWING

TYPES OF HALL MARKS

ON SILVER PLATE ${ }^{\text {I }}$

Used by the various Assay Offices :

London, Exeter, Chester,

Newcastle-upon-Tyne, York,

Sheffield, Birmingham,

Edinburgh, Glasgow,

Dublin, and Cork

- The Position of Marks.-Marks are not placed on old silver in a straight line. They are shown in this manner for convenience, and are the author's own arrangement. They are in practice irregularly stamped and sometimes upside down. The maker put his stamp on the piece prior to sending it to the Assay Office. The remaining stamps were done under the directions of the Wardens. Although the maker's mark was stamped first, some of the other marks were placed on either side of it. 


\section{CHATS ON OLD SHEFFIELD PLATE}

The following series of Hall Marks on Silver by the various Assay Offices are given as they fix the exact date when certain types of silver were made, and the maker's stamp with initials enables identification. It is only by comparison with original examples of dated silver that approximate dates can be ascertained of old Sheffield plate which set out to copy silver. Accordingly, the work of the following London makers should be studied with a view to establishing the original designers of many of the old Sheffield replicas. The following great masters came on the threshold of the Sheffield plate invention: Paul Crispin (I743); Paul Lamerie (I746); John Cafe (I749); Peter Taylor (Tea Caddies) (I747); Frederick Kandler (Inkstands) (I 757); Thomas Whipham (I747); John Swift (Coffee Pots) (I 749); Richard Rugg (I 754); William Grundy (I757); Edward Wakelin (I753); Isaac Duke (Sauce Boats) (I743); Simon Jouet (I 747); George Wickes (Candlesticks) (I750); Samuel Taylor (Caddies, Sugar Basins) (I756); Henry Herbert (I753).

When the Sheffield industry was at its height the following London makers had established a reputation for various classes of designs which they had made their own.

Sugar Basins (Fine pierced and festoon work): Benjamin Gignac (I76I); J. Denizlow (I78I); Henry Chawner (I792); L. Herne and F. Butty (I750); Daniel Smith and Robert Sharp (I 769); S. Herbert \& Co. (I 767 ).

Cream Jugs, Sauce Boats : Samuel Meriton (I76I); Walter Brind ( $(763)$; Parker and Wakelin (I775); James Wilkes (I784): Peter and Anne Bateman (I79I).

Candelabra and Candlesticks: Robert Hennell (I777); Wakelyn and Taylor (I782); John Tayleur (I786); John Schofield (I 786 ).

Centrepieces: William Plummer (Adam Style, I787).

Tureens and Services: Dave "Smith and Robert Sharp (I747); Thomas Heming (I772); William Pitts and Joseph Preedy (1793); Robert Sharp (Wine Coolers) (1803); Samuel Hennell (Wine Coolers) (1813); Paul Storr (I796-I820).

Punch Ladles: Dorothy Mills (I 77I).

Salt Cellars: Daniel Hennell ( 1758 ).

Inkstands : Thomas Heming (I 764 ).

Toasted Cheese Dishes: Thomas Heming (r 779 ).

Tea Urns : Orlando Jackson (I 77I).

Teapots and Coffee Pots: William Plummer (Teapots and Caddies) (I764); Frederick Knopfell (I765); Samuel Taylor (Caddies) (I770); W. Cripps (I762); Samuel Wood (I785); William Shaw (Caddies) (I788); Robert Garrard (I805); Philip Rundell (1819). 


\section{LONDON}

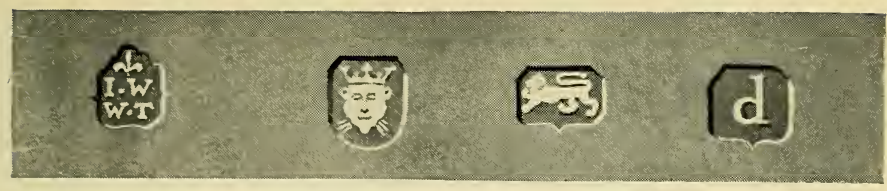

1779

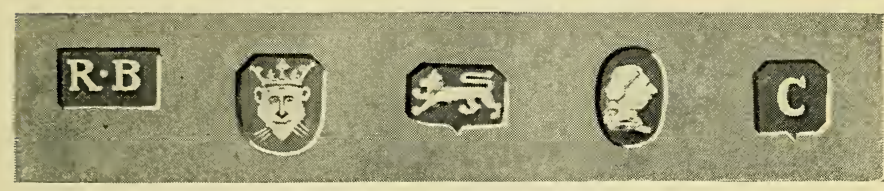

1798

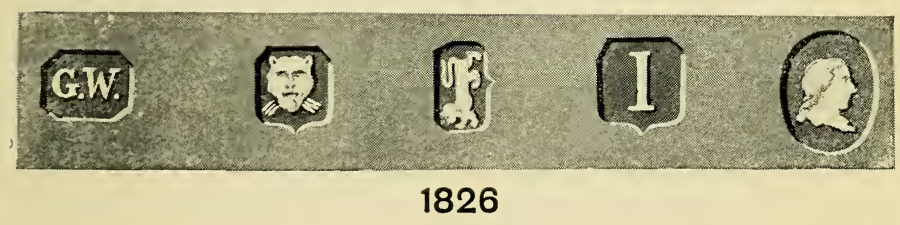

\section{EXETER}

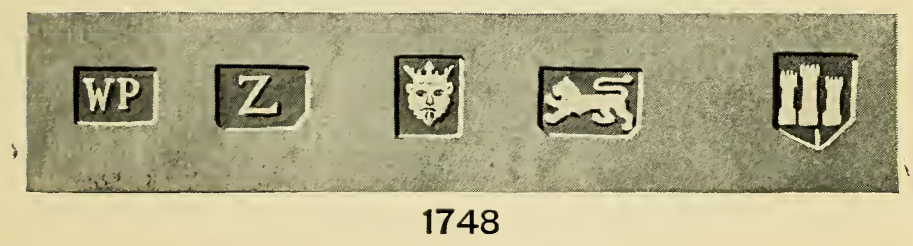



The date letters of the various London alphabets are readily ascertainable. The differences in the shape of the shields are not great; the leopard lost his crown in I82I and has been cat-like in appearance ever since. Exeter continued as an Assay Office till 1882, but York, which was not mentioned among the Assay Offices in 1773 , recommenced about the beginning of the nineteenth century and continued till 1870 . Its mark was a St. George's Cross and five diminutive Lions. Newcastle-upon-Tyne similarly discontinued assaying silver in I 884 .

Exeter.-The mark, as is shown, is a castle with three towers. The Date Letters were A-Y (1773-1796). The letter I was used for two years 1781 and I782. A-U (I797-I8I6) in square shield and a- $\mathbf{a}(1817-1836)$ in square shield with four corners cut off. About I775 the following silversmiths' marks are found on Exeter silver: Richard Jenkins, William Coffin, Richard Freeman, and Thomas Thorne (Plymouth), David Hawkins (Plymouth), William Harvey (Plymouth), Richard Bidlake (Plymouth).

Chester.-The Town Mark formerly was three Demi-Lions with wheatsheaves on a shield. In I 775 it was changed to three Wheatsheaves with a dagger, which is still in use at the Chester Assay Office. In addition there is the Lion passant and the Leopard's head denoting sterling silver, as at London.

Newcastle-upon-Tyne. - The complete Marks are the Lion passant, the Leopard's head, the Town or Hall mark of three Castles, the Date Letter, the Maker's Mark, and the Duty Mark of the sovereign's head used, as at all other offices, till I890, when the duty on silver plate was abolished.

Sheffield.-An Assay Office was established by Act of Parliament in 1773 ( 13 George III, Cap. 52), and Sheffield obtained the rights to hall mark silver. It is unfortunate that between 1773 and 1823 the date letters were taken at random. The difficulty of identifying silver plate between these two dates (an important period) is thereby increased by this irregular choice of the Guardians of the Wrought Silver Plate of Sheffield. It is as though they had designedly set conundrums for posterity which none of the other Assay Offices did with their regular series of date letters. But from I 824-1843 the alphabet denoting the date runs from $\mathbf{a}-\mathbf{z}$ (the letters $i, j, \mathbf{n}$, $o, w$ and $y$ being omitted), and from $1844-1867$ the alphabet was $\mathbf{A}-\mathbf{Z}$ ( $\mathbf{J}$ and $\mathrm{Q}$ being omitted). 


\section{CHATS ON OLD SHEFFIELD PLATE}

The marks on the opposite page have been taken from specimens of silver plate hall-marked by the various provincial Assay Offices.

The Chester silversmiths made a variety of excellent plate. There was Richard Richardson whose designs were in the Queen Anne style, and doubtless attracted the attention of Sheffield. In 1768 Bolton and Fothergill made a variety of articles, including some fine candlesticks, and other silversmiths about I775 whose marks were stamped at Chester are: Geo. Walker, Jas. Dixon, Gimble and Vale (Birmingham), John Gimlet (Birmingham), Ralph Wakefield (Liverpool), Christian Thyme (Liverpool), and Ralph Fisher (Liverpool).

The mark given of the Newcastle-upon-Tyne Assay Office is from a Coffee Pot. Although of a slightly earlier period it exhibits the type of mark. Newcastle - produced many tankards, teapots and coffee pots of plain character and simple form that Sheffield in the early days might have essayed to copy. The following names of the Newcastle makers may assist possessors of Sheffield plated ware to establish a parallel : Isaac Cookson (1752); Robert Makepeace (sauceboats) (I754); Langlands and Goodriche (I754); Langlands and Robertson (I794).

At York in 1819 Robert Cottle and J. Barber were at work as silversmiths. A teapot of that date made by them exhibits fine design.

Early after the passing of the Act in 1773 the Sheffield silversmiths distinguished themselves by producing fine candlesticks, and among the early makers' marks with the Sheffield hall mark of the Crown as the Town Mark of Sheffield, is that of Samuel Roberts \& Co., and this is found together with the mark of the Lion passant and the Leopard's head. Another mark on candlesticks of silver (I79I) is I. P. \& Co. (J. Parsons $\&$ Co.). That Sheffield made silver plate before this is shown by the evidence before the Select Committee of the House of Commons in 1773 , alluded to on page 63 . 


\section{CHESTER}
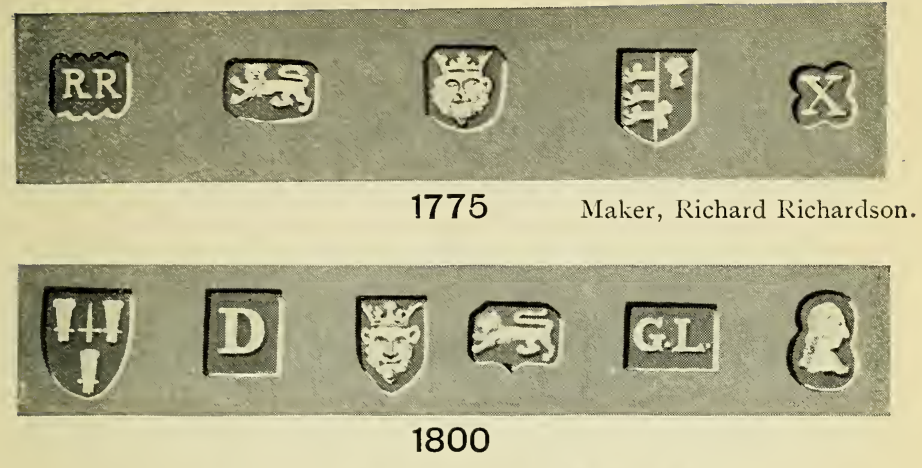

\section{NEWCASTLE-UPON-TYNE}

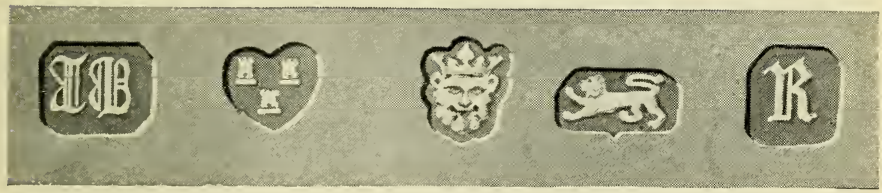

1737

\section{YORK}

\section{$\sqrt{\text { बe }}$
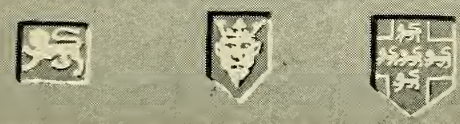

1800

\section{SHEFFIELD}

\section{(I.S.)}
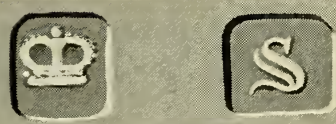

1778 

The Birmingham Assay Office came into being in $\mathbf{1} 773$ under the same Act as that governing Sheffield (I3 George III, Cap. 52). The marks are an Anchor (the Town Mark), a Lion passant, Date Letter, Maker's initials, and the Duty Mark of the sovereign's head from 1776 .

Scottish marks come under another series of Acts and are a field to themselves. Besides Edinburgh and Glasgow marks the number of Scottish marks is legion (Sterling, Perth, Inverness, Dundee, Aberdeen, Banff, etc.).

Edinburgh used the Standard mark of the Thistle after I759 in place of the Lion passant found on English silver. The hall mark is a Castle with three towers. The alphabets of Date Letters $A-Z$ and the Maker's initials have been regularly used since the fifteenth century. The Duty Mark of the sovereign's head was added in 1784 . It was also formerly usual to add the Assay master's initials.

Glasgow, in honour of her patron saint, St. Kentigern (known also as St. Mungo) has a hall mark of a Tree with a bird on uppermost branches, a Bell suspended and a Salmon transversely across the trunk. This fish has a ring in its mouth, the latter alluding to the miracle of the recovery of the last ring of Queen Caidyow. The Standard Mark is the Lion Rampant, used after I8I9, and the Maker's Mark his initials. The Duty Mark of the sovereign's head was the same as at Edinburgh.

Dublin marks have a figure of Hibernia, a Harp and Crown, together with Maker's Mark and the Date Letter. The Cork marks are varied. Sometimes there is a castle stamped twice and sometimes only the word STERLING and the Maker's initials or mark. 
Birmingham.-Among the makers of silver plate we find Matthew Boulton, who also made plated ware, with fine silver candlesticks with the hall mark and date letter for I794. The date letters of the Birmingham alphabets run: $\mathbf{A}-\mathbf{Z}$ Roman capitals (I773-I798); a-z small Roman (I798-1824); $\mathfrak{Z}=\mathbb{Z}$ Old English capitals (1824-1849); etc.

Edinburgh.-Among the well-known makers are Joseph Kerr (1790) and Patrick Robertson (I778). An example is given of the mark of the latter found on a Coffee Pot made in 1769 .

Dublin.-There are a number of makers with a reputation for fine designs. R. Calderwood (I760); George Beere (I 760 ) ; J. Laughlin (I765); Stephen Walsh (I765); W. Townshend (1765); Will Hughes (I770); William Homer (I77I); Darby Kehoe (I77I); Capel Harrison (I77I): Thomas Lilly (I772); Charles Townshend (I773): Thomas Jones (I 775); Robert Williams (I 776); John Nicklin (I780); Matthew Walsh (I780); William Law (I790); Matthew West (I79I) ; Robert Breading (1802); and James le Bas (1819). The initials of these makers will be found on Irish silver of the period.

Cork.-Here there were fine designs of an unusual character produced. Robert Goble, an early maker, had left a tradition. There was George Hodder (I 745-I 770) who made fine coffee pots and other articles. John Williams (I780) who produced sugar baskets finely pierced and chased in classic style, and there was Jonathan Buck, who was renowned for his magnificent repoussé and chased work in cream jugs and the like, who signed his pieces sometimes " J. Buck," in script, and sometimes stamped them with the mark of the buck. 


\section{BIRMINGHAM}

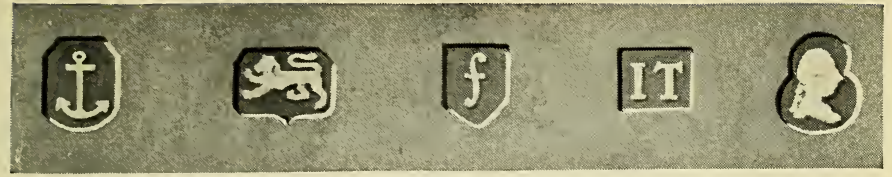

1804

\section{EDINBURGH}
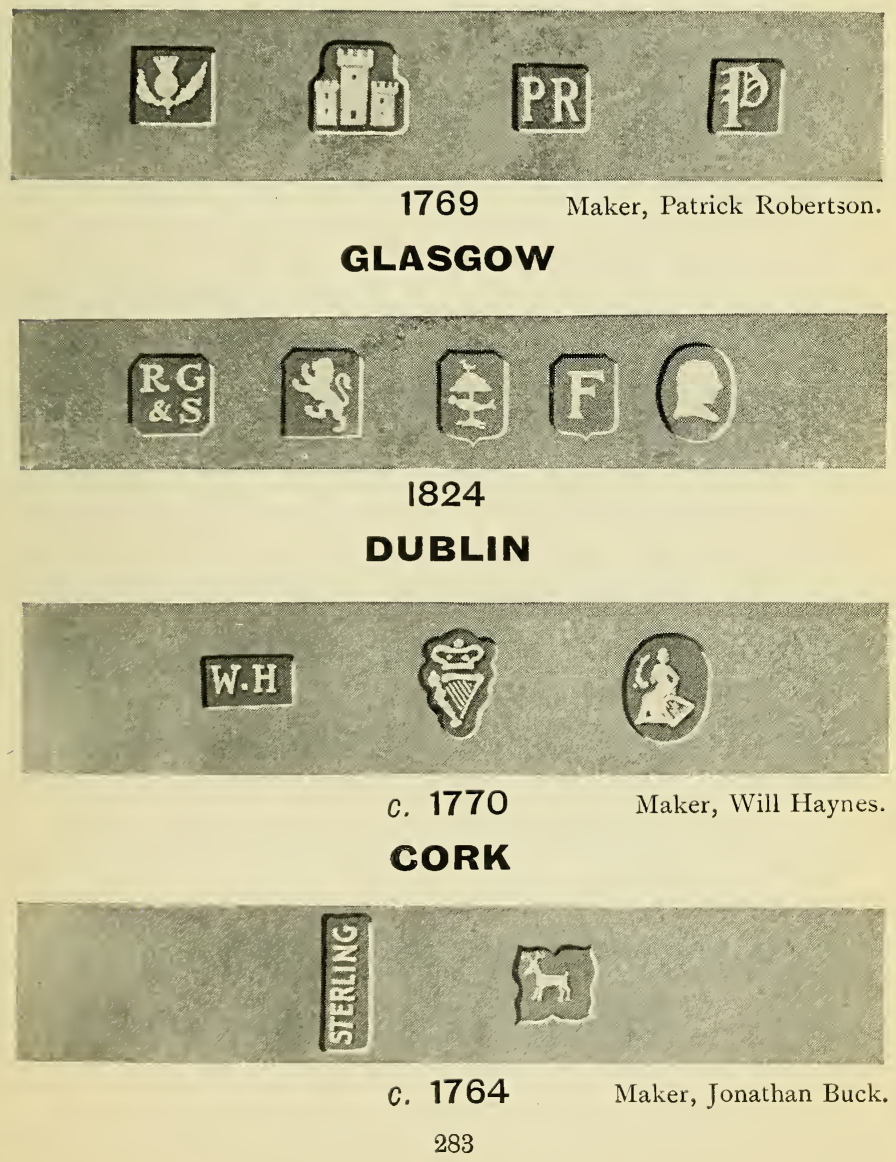



\section{II}

\section{EXAMPLES OF MARKS}

Found on old

Sheffield Plate

during the period

from 1753 to 1840

together with Marks on

French Silver Plated Ware 


\section{CHATS ON OLD SHEFFIELD PLATE}

The bell, the crossed arrows (three and four), the crossed keys, the pineapple, the orb, the hand, are all marks used by Sheffield makers. The following firms are well known:Roberts, Cadman \& Co., Goodman \& Co., Parsons \& Co., Wilkinson \& Co., Williams \& Co., Dixon and Sons, Holy \& Co., Gainsford, Walker Knowles \& Co., all of Sheffield. At Birmingham there was Matthew Boulton, and the Soho Co., Hardy and others. In London there were many firms settled in the Soho district.

The cross keys, illustrated, is the mark of $\mathrm{H}$. Wilkinson \& Co. (formerly John Parsons \& Co.), Sheffield, though during what period this was used is not determined. The Orb (that is, the ball and cross) was the trade mark of Walker Knowles \& Co., Sheffield, but exactitude in regard to the period of its use is lacking. The open hand was the sign of Messrs. Watson, Sheffield, and the crossed arrows of Messrs. Fenton, Creswick \& Co., Sheffield.

The original firm Roberts, Cadman and Co., who commenced business in 1784 , used the Bell as a mark. They also used, as is illustrated, R.C. \& Co. and R.C. \& Co. Patent. The latter mark is stamped on a candlestick made about 1797. In the same period Roberts, Cadman \& Co. produced Coffee Pots with "Ivory Pine Knob" as advertised in their catalogues of that date. There were Tinder Boxes at Ios. 6d. each with extinguisher with chain and candlestick on top. The Tea Urns were priced at twelve guineas " circular or globular shaped." The Tea Caddies plated inside with silver edges were $45 \mathrm{~s}$. each, and some cups and cream ewers were "gilt inside." They made also at this date Lamp Holders to fit into candle sockets, and Taper Holders.

The firm afterwards became Roberts, Smith \& Co., then Smith, Sissons \& Co., and were succeeded by W. \& G. Sissons, who are still continuing the business and are silversmiths and electro-platers.

The three crossed arrows mark is interesting. It is claimed to have been used by Messrs. Fenton, Creswick \& Co., Sheffield. The mark illustrated with four crossed arrows is that of T. \& J. Creswick (I8II). With it is given another crossed arrow mark of two crossed arrows adopted by the Sheffield Assay Office to stamp on Foreign silver assayed at that office in I904; before that only the letter $\mathrm{F}$ in an oval was used, but by 4 Edward VII, Cap. 6 all Assay Offices had to adopt a new style, and Sheffield selected the crossed arrows. In I906 the mark was changed to the one illustrated, which is still used on foreign silver sent to Sheffield for assay and sale in this country. 


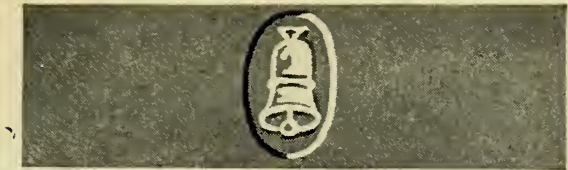

Mark of Roberts, cadman \& Co., ShefField (1784).

The firm became Roberts, Smith \& Co., then Smith, Sissons \& Co., and is now Messrs. W. \& G. Sissons, who still use the mark.

(See illustrations from R. C. \& Co.'s Pattern Books, pp. 75, 183.)

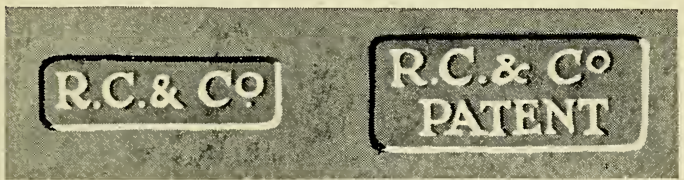

Marks of Roberts, Cadman \& Co.

Found on Candlesticks with silver edges.

In 1824 Roberts of Sheffield took out a patent for a new method of applying silver edges to snuffer trays, cream jugs, sauce boats, \&c. These are found stampcd SILVER:EDGD.

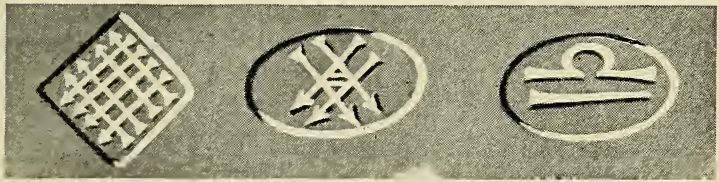

MARK OF THOMAS \& JAMES CRESWICK, SHEFFIELD (1811).
MaRks on Foreign Siller Plate (1904.) ASSAYED AT SHEFFIELD.

(1906.

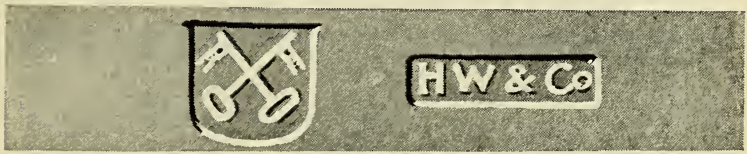

John PaRsons \& Co. USED THE MARK OF THE Crossed Keys From 1784.

(See Illustrations from Pattern Books, pp. I4I, I45, I5I, I79, I9I.)

The Mark as above is that of H. Wilkinson \& Co., their successors. 



\section{MARKS ON OLD SHEFFIELD PLATE 289}

Many fine examples of old Sheffield plate are unmarked. Where marks are found it is not always possible, except by inference, to determine at what particular date the makers stamped such marks, that is at what date the specimen was made. Obviously the style of decoration indicates approximately the period, as the Sheffield platers set out to offer ware as fashionable as silver. This is determinable by comparison with similar examples made by the silversmiths. But whereas silver plate was accurately dated when it bore the stamp of the annual date letter, wherever made, Sheffield plated ware cannot offer this exactitude.

Marks when found are useful as indicating the initials of old firms who have manufactured plate from the earliest period and are still in business. But many of the marks were used over a long period and only by comparison with silver prototypes can dates be arrived at.

It has been shown (p. 63) that in 1773 when Sheffield and Birmingham were made Assay towns that silver plate was being made there, contemporaneously with plated wares and presumably by the same firms. The evidence before the Parliamentary Committee in 1773 showed that Sheffield had her silver assayed in London, and that Birmingham had also some of her silver assayed in Chester. It therefore follows that many examples of silver plate bearing the London and Chester hall marks were made at Sheffield and at Birmingham-and in the period from the invention of plated ware at Sheffield by Boulsover till the year $\mathbf{1} 773$.

One of the weakest points in regard to marks on plated ware is undoubtedly the absence of real proof as to date. Similar marks are found covering a period too long for one maker's working lifetime. It follows that they represent firms; often accompanying these, though not always, are signs also found through a long period and on various classes of ware, which are stated to be workmen's marks. In old Worcester china signs not understood and standing apart from the factory mark of the crescent or the square Chinese mark are attributed to workmen. There identity ceases. It is the same, unfortunately, with old Sheffield plate. That the Sheffield platers did attempt to simulate the London marks on silver plate is only too true. In some examples with a row of marks, a very colourable imitation of the leopard's head is seen and the public might well be deceived. But after 1773 this practice became too dangerous. In fact the penalties were so severe that makers feared to mark plated goods until the 1784 Act laid down clearer rules. 


\section{CHATS ON OLD SHEFFIELD PLATE}

The mark consisting of four stamps about $181_{5}$ in date is interesting. TThe casque suggests a head, and the fleur-de-lys might, when worn, suggest the Sheffield crown on silver plate. The $\mathbf{G}$ has all the appearance of a date letter. Such marks have a somewhat sinister appearance, as they undoubtedly by their number and character were attempting to simulate the hall marks on silver plate.

In regard to Foreign marks on silver plated ware that was produced in the method of old Sheffield, there are examples known to have been made in France and in Russia, and it is believed that they were also made in Holland and in Sweden. The promulgation of the old Pattern Books by Sheffield at the end of the eighteenth century doubtless had an influence on metal workers on the Continent, who were never slow in assimilating new processes, especially when they offered, as did Sheffield, a lessened cost of production and an appearance simulating something finer.

The legal enactments relating to the marking of French plated ware are referred to on p. 209.

The illustrations of marks found on French silver plated articles are interesting. The authorities were strict in regard to an exact definition in the mark to denote to the public the exact nature of the ware offered for sale. In contradistinction to the slovenliness of English marking this exhibits the logical and protective system devised under French laws. The articles had to be stamped Doublé (replica) or Plaqué (plated), and as is shown in the illustration in no illegible manner. There was no simulation of the French silver plate marks allowed, and the quantity of silver was duly stamped roM or $20 \mathrm{M}$, as the case might be. The maker, as will be seen, had his mark, but it took a subsidiary place. The public had to be protected first.

In regard to Close Plating, which as a process came about the beginning of the nineteenth century, and was applied to smaller articles where the rolled sheets were not applicable, there are a number of marks found on forks and spoons, snuffers and skewers, on spurs and buckles, dessert knives and forks, and other articles of a like nature.

Electro-plating was discovered about 1840 , and a patent was taken out by George and Henry Elkington of Birmingham at that date.

The electro-plated marks are imposing. In worn examples the row of five stamps is not decipherable. What they were originally it is not easy to say, but they have been designed to appear more important than they are. 


\section{$\sqrt{3}$ \\ $\left[\begin{array}{c}5,3 \\ 3\end{array}\right]$}

Mark of Matthew Boulton, Soho Plate Works, BIRMINGHAM.

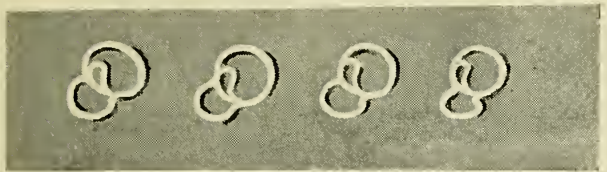

ShaM MaRks STAMPEd ON SHEFField Plated WARE to simulate the Hall Marks on Silver Plate.

(Found on late Eighteenth-Century Hot Water Jug.)

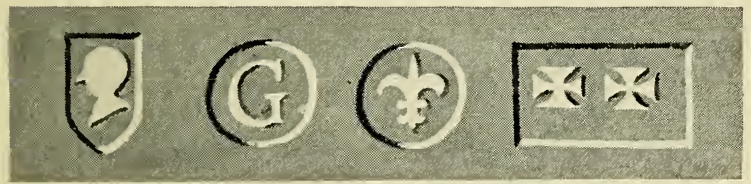

IMitation Marks Stamped on ShefField Plated Ware to simulate Hall Marks on Silver Plate.

(Found on Salt Cellars in date about 1815.)
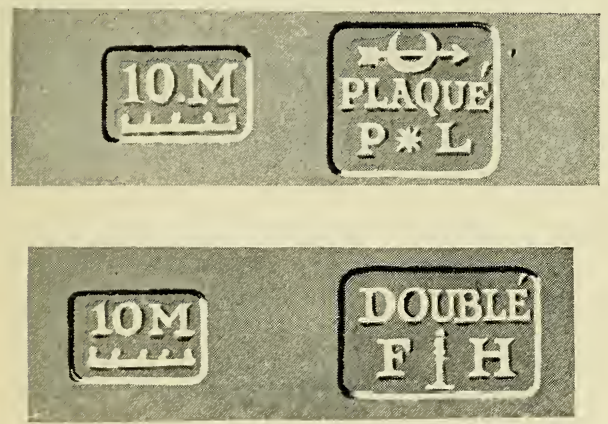

Marks on French Silver Plated Ware, PlaQUÉ or DOUBLE, CLEARLY SHOWING THAT IT IS PLATED, ANd Not Silver Plate.

The upper mark (Plaqué) is on a Tureen about 1816.

The lower mark (Doublé) is on the Coffee Pot illustrated (p. 2 I I). 

A great number of marks appear on close plated articles. Horday \& Co., S.G., E.S., S.J. and others. But their identity is not known. Nor is it very significant. An interesting mark, Sly. Dublin, is found on a skewer in the early period.

Probably seventy-five per cent. of examples of old Sheffield plate are unmarked, though they exhibit fine craftsmanship which any maker might well have been proud to have stamped with his initials had the Act of 1773 been framed sufficiently clear to enable makers to venture stamping plated ware at all with safety. Anonymous, therefore, as most of the best Sheffield plate of the best period is, it bears on the face of it the hall mark of exquisite workmanship.

Collectors of old Sheffield plate make a great mistake in constantly demanding that examples be marked. If this demand for marks on old Sheffield plate be insisted upon, the marks will accordingly be supplied. There is nothing to prevent stamps being made to represent some of the marks found on old Sheffield plate, and unmarked pieces will soon bear marks and straightway become more saleable. The public by incessant clamour drive those responsible for providing for its wants into devious paths. The dealer in old Sheffield plate has scores of fine unmarked examples and he is wishful to sell them as such.

They are undoubtedly old and of fine quality. It should be the ideal of the collector to know the technique of his subject so well that the artistic beauty and the skilful craftsmanship of an example should make its appeal to his trained scrutiny irrespective as to whether there is any maker's mark on the piece or not. The seams on old pieces showing joins are a far better test of old workmanship as between old Sheffield plating and modern electro-plating. These seams are the hall marks of the makers a century and a century and a half ago. 

INDEX 



\section{INDEX}

Abbotsford, Scott's introduction of gas at, II 6

Adam design, example of hot water jug, 228

Adam style of design, the, 85 Addison omits Shakespeare from list of great poets, $5 \mathrm{I}$ Advertisement of Pinchbeck (I732), 54

Allan David, copyist of old masters, 2 I

Anonymity of Sheffield plated ware, 289

Arrows, the crossed, as a mark, various types of, 286

Artistic value of old Sheffield plate, 60, 6I

Assay offices, examples of marks used at, $274-282$

"Below the salt," its meaning, 136

Birmingham Assay Office, institution of, $4 \mathrm{I}$

Birmingham-

hall marks on silver plate, $28 \mathrm{I}$

its silver plated marks registered at Sheffield, 68 silver platers, rise of, 68

Boulsover, Thomas (I704I788), inventor of Sheffield silver plating, 46 obituary notice of, 47
Boulton, Matthew, Birmingham (Boulton and Fothergill), (M. Boulton and Co.), 68

Buckle makers, the, 262

Buttons made by Thomas Boulsover, 47, 53

Button makers in Dublin (I 792), 73

Cabinet makers, French, stamped marks of, 237

Caddies, tea, and their makers, r 96

Cadman, Robert, and Co., (Sheffield), 89

Cake baskets, Sheffield plated, 165

Candelabra-

and candlesticks, 79-I $3 \mathbf{I}$

old silver, London makers of, 274

Candelabrum, theits varieties, 90 the tri-form, II 5

Candlestickthe chamber, II 9 the table, I20

Candlesticksearly types, $8 \mathrm{r}$ from eighteenth century Pattern Books, 74, 86, 89 old silver, London makers of, 274 
Candlesticks (continued)-

Sheffield plated, their price, 269

Carteret's “Drunken Administration," 48

Centrepiece, the, 245

Centrepieces, old silver, London makers of, 274

Chair-backs, a test to apply to their beauty, I09

Chester hall marks on silver plate, 277

Chester-Liverpool, and Birmingham silversmiths' work assayed at, 278

China factories, Derby and Worcester, origin of, 49

Chippendale chair-backs, the test of their beauty, rog

Christie's, price of Sheffield plated candlesticks sold at, 269

Close plating, 26I

Coasters (decanter stands), I66

Coffee pots, 206

Coffee pots, old silver, London makers of, 274

Contemporary silver designs in Sheffield plated period, $274,278,281,282$

Continental trade, Sheffield platers and, 154

Copyists of old masters, 2 I

Cream jugs, old silver, London makers of, 274

Danger of public clamour for marks, 293

Date of examples, Sheffield plated, absence of proof of, 289

Death penalties for tampering with silver plate, Geo. III (I8I5), 48

Decanter stands, 166
Decadence in design, in candlesticks, I26

Design Book, Sheffield Plate, eighteenth century, I39

Designer, the, his greatest asset, what to omit, rog.

Destruction of old Sheffield plate, 253

Die work in Sheffield plating, 82

Dies, destruction of old Sheffield plate, 250

Dinner table, passing of the, 254

Dish rings, Sheffield plated, I 77

Drunken habits of eighteenth century, 189

Duties on silver, eighteenth and nineteenth centuries, $4^{8}$

Economic substitution, 22

Electro plating, its invention, 290

Empire style candelabrum, I 6 English craftsmanship, imitativeness of, 27

English porcelain factories, origin of Derby and Worcester, 49

Engraving, not an imitative art, 28

Engravings, when printed in colours, imitative art, 28

Epigram by Porson on Pitt, I 89 on weight in plate, 202

European imitativeness, 25

Exeter hall marks on silver plate, 277

Factory system, the, 268

Fashion of buckles, decline of the, 263

Foreign policy, Carteret's pronouncement on his, 48 
Foreign silver plating in Sheffield style, 290

Fraud by silversmiths, penalties against, 35

\section{French-}

marks on silver-plated ware, 290

plating, an early process, 39

plated ware, regulations regarding, 209

Garrick, David, his revival of Shakespeare, 50

Gas introduced to light Abbotsford, II 6

George IV and the fashion of buckles, 263

German silver and other white metals, 267

Gin bottle covered with bead work, 26

Glass designs imitate silver, 35

Glass, Venetian, copied in Germany, 25

Goltzins simulates prints of old masters, 20

Grease pans, their indication of date, 99

Guido picture fabricated by Mignard, 20

Hall marks on old silver, illustrated, 275, 279, 283

Hancock, Joseph (Sheffield), his share in developing silver plating, $6 \mathrm{I}$

Herculaneumdesign from, i 6 influence of art of, II 6

Hogarth, "the Scottish," David Allan, 2I

Imitativeness, European, 25
Imitation-

as a fine art, 19

of hall marks by Sheffield platers, 289, 290

decadence of wood engraving, 4I

Imitations of Sheffield plate, I 58

Inkstands, I 8 I

Invention of silver plating by fusion, 45

Ireland, silver plating by fusion carried on in, $7 \mathbf{I}$

Irish dish or potato rings, I 77

Irish Government offers premium ( 1783 ) for plated ware made in Ireland, $7 \mathbf{I}$

Irish hall marks on silver plate, 281,282

Irish plated skewer marked "Sly," 262

Jackson, John, copyist of Reynolds, 2 I

Jugs, hot water, 227

Kettles, tea, 205

Knick-knacks, a world of (eighteenth century), 54

Knife handle of stamped Sheffield plate, 50

Lamb, Charles, quoted, 136

Liverpool silversmiths' work assayed at Chester, 278

Liverseege, Henry, copyist of Vandyck, 2I

London, silver plating carried on at, 68

Louis XIV-

orders silver plate to be melted, 23

his extravagant use of silver plate, 23 
Marks-

on French cabinet work, 237 on porcelain, 232

on Sheffield plate; 62,63 , 23I ; (illustrated), 286-293 (Sheffield plate) fear of platers to stamp any, 64, 67

on Sheffield plate resembling silver marks, 62,63

on silver, position of, 273

Melting down of old Sheffield plate, 253

Mignard fabricates a Guido picture, 20

Missionary-fostered art, 26

Mustard pot, the, 148

Newcastle-upon-Tyne-

hall marks on silver plate, 277

silversmiths at, 278

Nottingham, silver plated ware made at, 68

Nozzles, removable, their indication of date, 96

Old masters, drawings of, copied by David Allan, 2 I

Old masters, prints of, simulated by Goltzins, 20

Original silver plate design copied by platers, 143

Ornamentspiral, its abuse, 106 useless, failure of, I 10

Parliamentary Committee on conduct of assay offices (I 773), 63

Parsons and Co., Pattern Book, I 81

Patch boxes, Sheffield plated, 54
Pattern Books, eighteenth century, silver platers', $74,86,89,139$

Penalties-

counterfeiting Duty Mark (I8I5) punishable by death, 48

for fraud in old plate, 36,62 , 63

for wrongly stamping Sheffield plate, 67

Petition of the buckle makers, the, 264

Pinchbeck, Christopher, and his imitations, 54

Pipe lighter-

Sheffield plate, 24!

illustrated, 239

Pitt, epigrams by Porson on, 189

Plating, silver-

early, 35

pre-fusion period, 35, 39

process described, 58

used fraudulently, 35

Pompeii, influence of art of, I 16

Poor relations and their foibles, 136

Porcelain factories, Derby and Worcester, origin of, 49

Potato rings, Sheffield plated, I 77

Potters, copy of silversmiths' designs by, 28, 3 I

Pottery, French, supplants silver plate, 24

Pounce pot, the, and its use, 182

Prince of Wales's feathers used in design, 153

Process of Sheffield silver plating described, $5^{8}$

Rise in value of old Sheffield plate, 269 
Romney picture of Serena (Miss Sneyd), I I 9

Ruskin and copies of Turner drawings, 22

"Salt, below the," its meaning, 136

Salt cellar, the, I35

the new style, 147

Sauce boats, old silver, London makers of, 274

Scott, Sir Walter, his introduction of gas at Abbotsford, I 6

Scottish hall marks on silver plate, 28I

Seams a test of genuineness in Sheffield plate, 293

Sevrès porcelain makers' marks, 232

Shakespeare neglected by Addison and Steele, 5 I revival of study of, 50

Sheffield-

Assay Office, institution of, 40, $4 \mathrm{I}$

hall marks on silver plate, 277

origin of silver plating at, 39

Sheffield plate-

old, destruction of, 253

wonderful technique of, I6I

Sheffield platers-

as to their originality, I43

deterred from placing any marks, 64,67

Sheffield silver plate, makers of, eighteenth century, 278

Sheffield, silver plating process Silverdescribed, 58

duties in eighteenth and nineteenth centuries, 48 price of, in eighteenth century, 47
Silver (continued)-

lustre ware imitates silver plate, 35

marks, simulation of, by marks on Sheffield plate, 62,63

plate designs copied by platers, I 43

plate made at Sheffield assayed in London, 63

plate, value of hall marks on, 274

plating at Sheffield, origin of, 39

plating by fusion, its invention, 45

plating, early, 35

plating, the great period, 73

Silversmiths-

copy of potters' designs by, 28,31

list of late eighteenth century, 77

(London) who influenced Sheffield platers, 274

Simulation in art, 25, 28

Smith, J. R., engraving of Serena after Romney, II 9 Spiral forms in candelabra, Ioo

Spectator, advertisement in (I 7 I2), 140

Spurious candelabra and their errors, 95

Steele, Richard, omits Shakespeare from list of great poets, $5 \mathrm{I}$

Steel toys, the, of Sheffield, I 40

Sugar basin, the, 2 ro

basins, old silver, London makers of, 274

Supper table, the, 238

Taper holders, $\mathbf{I} 8 \mathbf{I}$

Tea and coffee sets, 201 
Tea caddies and their makers, 196

Tea kettles, 205

Teapots, 189 old silver, London makers of, 274

Tea urn, the, 202

Techinque, wonderful, of Sheffield plate, $16 \mathrm{I}$

Tinder boxes, Sheffield plated, 286

Toasted cheese dishes, old silver, London makers of, 274

Trencher salts, their use, 147

Tureens-

old silver, London makers of, 274

soup, 220

Turner drawings, facsimiles of, 22

Tutenag, an alloy of antimony and zinc, 267

Urn, the tea, 202
Utility the true test of ornament, I Io

Value of old Sheffield plate, 269

Ward, his replicas of Turner drawings, 22

Wedgwood, Josiahshell-forms, adoption of, $3 I$ carved wood models, use of, 3 I indebted to metal-workers of Sheffield, 32

White metals, German silver, etc., 267

Wine coolers, old silver, London makers of, 274

Wine labels, Sheffield plated, 53

Wood engraving, decadence of, $4 \mathrm{I}$

Worcester china, workmen's marks on, 289

York, silversmiths at, 278 
L IST OF VOLUMES

Chats on English China. By ARthur Hayden. Illustrated with reproductions of 156 marks and 89 specimens of china. Cloth, 9s. net.

Tenth Impression.

This is the standard work on the subject. The volume will enable the possessors of old china to determine the factories at which their ware was produced. "It gives in a few chapters just what the beginner wants to know about the principal varieties of English ware. We can warmly commend the book to the china collector." Pall Mall Gazette.

"So simply yet so thoroughly written, that it is a sage guide to the veriest tyro in china collecting."

Bookman.

Chats on Old Furniture. By Arthur Hayden. With a coloured frontispiece and 104 other Illustrations. Cloth, 9s. net. Fourth Edition.

Twelfth Impression.

"The hints to collectors are the best and clearest we have seen ; so that altogether this is a model book of its kind."

"A fully illustrated practical guide for collectors."

Athenoum. The Times.

"Mr. Hayden has worked at his subject on systematic lines, and has made his book what it purports to bo-a practical guide for the collector."

The Saturday Review.

Chats on Old Prints. How to Collect and Identify. By ARThur HAYDEN. With a coloured frontispiece and 72 full-page plates. Cloth, 9s. net. Seventh.Impression. Every branch of the subject is carefully and explicitly handled in this book, and valuable information as to technical processes and identification of prints is given. "If there is a better book of its kind on print collecting we have not yet come across it."

Daily Graphic. "A very useful handbook for beginners, intended to help any reader of artistic tastes, but very moderate means, to collect to good purpose."

The Times.

Chats on Costume. By G. Woolliscroft Rhead, R.E. With a coloured frontispiece and $\mathbf{1 1 7}$ other Illustrations. Cloth, 9s. net.

Second Impression.

A practical guide to historic dress. "Clothes" is a subject that has been neglected by collectors, and this book will be a useful guide to those who desire to repair that neglect by forming a collection. "A book that is at once the work of an authority on the subject of costumes, and one that helps to enlarge our range of selec. tion."

Pall Mall Gazette.

T. FISHER UNWIN LTD. 1 ADELPHI TERRACE, LONDUN, W.C. 2 


\section{U N W I N'S “C H A T S" SER I E S}

Chats on Old Miniatures. By J. J. Foster, F.S.A. With a coloured frontispiece and 116 other Illustrations. Cloth, 9s. net. Second Impression. This book presents in a concise and popular form a variety of valuable information on the collection and preservation of miniatures, on the leading English and French artists, and on the specimens exhibited in public galleries. "Mr. Foster is truly a guide, philosopher and friend. He tells us not only how to judge and how to buy miniatures, but how to take proper care of them.... The splendid photographs by which the book is enriched adds in a great measure to its attractiveness and utility."

Aberdeen Free Fress.

Chats on Old Lace and Needlework. By Mrs. Lowes. With a frontispiece and $\mathbf{7 4}$ other Illustrations. Cloth, 9s. net. Third Impression.

Written by an expert and enthusiast in these most interesting branches of art. The low price at which the work is issued is exceptional in dealing with these subjects, and it is remarkable in view of the technical knowledge displayed and the many photographic illustrations which practically interleave the book. "In commendable, clear and concise style Mrs. Lowes explains the technical features distinguishing each example, making the book the utmost value in identifying samples of old lace."-Weldon's Ladies' Jour.

Chats on Oriental China. By J. F. Blacker. With a coloured frontispiece and 70 other Illustrations. Cloth, 9s. net. Fifth Impression.

Will be of the utmost service to collectors and to all who may have old Chinese and Japanese porcelain in theirpossession. It deals with oriental china from the various standpoints of history, technique, age, marks and values, and is richly illustrated with admirable reproductions. "A treatise that is so informing and comprehensive that it commands the prompt recognisation of all who value the choice productions of the oriental artists. ... The illustrations are numerous and invaluable to the attainment of expert knowledge, and the result is a handbook that is as indispensable as it is unique." Pall Mall Gazette.

T. FISHER UNWIN LTD., 1 ADELPHI TERRACE, LONDON, W C. 2 


\section{U N W I N'S “CHATS” SER I ES}

Chats on English Earthenware. to "Chats on English China." With a coloured frontispiece, 150 Illustrations and tables of over 200 illustrated marks. $9 \mathrm{~s}$. net. "To the ever-increasing number of collectors who are taking an interest in old English pottery ... will be found one of the most delightful, as it is a practical work on a fascinating subject."

Hearth and Home.

"Here we have a handbook, written by a well-known authority, which gives in the concisest possible form all the information that the beginner in earthenware collecting is likely to need. Moreover, it contains one or two features that are not usually found in the multifarious 'guides' that are produced to-day."

Nation.

Chats on Autographs. By A. M. BroADLEY. With 130 Illustrations.

Cloth, 9s. net.

"Being an expert collector, Mr. Broadley not only discourses on the kinds of sutograph he owns, but gives some excellent cautionary advice and a valuable 'caveat emptor' chapter for the benefit of other collectors."

Westminster Gazette. "It is assuredly the best work of the kind yet given to the public; and supplies the intending collector with the various sources of information necessary to his equipment."

Manchester Guardian.

Chats on Old Pewter. By H. J. L. J. Massé, M.A. With 52 half-tone and numerous other Illustrations. Cloth, 9s. net. Third Impression.

"It is a remarkably thorough and well-arranged guide to the subject, supplied with useful illustrations and with lists of powterers and of their marks so complete as to make it a very complete and satisfactory book of reference."

Manchester Guardian.

"Before setting out to collect old pewter it would be as well to read Mr. Masse's book, which is exhaustive in its information and its lists of pewterers, analytical index, and historical and technical chapters."

Chats on Postage Stamps. By Fred J. Melvillue. With 57 half-tone and 17 line Illustrations. 9 s. net. Second Impression.

"The whole book, with its numerous illustrations of excellent quality, is a vade mecum for stamp collectors, even though their efforts may te but modest; we congratulate Mr. Melville on a remarkably good guide, which makes fascinating reading."

Academy. "There is no doubt that Mr. Melville's book fills a void. There is nothing exactly like it. Agreeably written in a popular style and adequately illustrated, it is certainly one of the best guides to phila. telic knowledge that have yet been published."

World.

T. FISHER UNWIN LTD., 1 ADELPHI TERRACE, LONDON, W.C. 2 
Chats on Old Jewellery and Trinkets. By MacIver Percival. With nearly 300 Illustrations. Cloth, 9s. net. "The book is very thorough, dealing as it does with classic, antique and modern ornaments; with gold, silver, steel and pinchbeck; with the precious stones, the commoner stones and imitation."-Outlook. " 'Chats on Old Jewellery and Trinkets' is a book which will onable every woman to turn over her jewel-case with a fresh interest and a new intelligence; a practical guide for the humble but anxious collector.... A good glossary of technicalities and many excellent illustrations complete a valuable contribution to collector's lore."

Illustrated London News.

Chats on Cottage and Farmhouse Furniture. A companion volume to " Chats on Old Furniture." By ARTHUr HAYDEN. With a coloured frontispiece and 75 other Illustrations. Cloth, 9s. net. Third Impression. "One gets very much for one's money in this book. Seventy-three full-page illustrations in half-tone embellish a letterpress which is replete with wise description and valuable hints." Vanity Fair. "Mr. Hayden's book is a guide to all sorts of desirable and simple furniture, from Stuart to Georgian, and it is a delight to read as well as a sure help to selection."

Pall Mall Gazette. "Mr. Hayden writes lucidly and is careful and accurate in his statements; while the advice he gives to collectors is both sound and reasonable."

Westminster Gazette.

Chats on Old Coins. By Fred W. Burgess. With a coloured frontispiece and 258 other Illustrations. Cloth, $9 \mathrm{~s}$. net. Second Impression. "A most useful and instructive book . . . will prove a boon to the intending collector of old coins and tokens, and full of interest to every collector. As was to be expected of any volume of this series, the illustrations are numerous and good, and greatly assist the reader to grasp the essentials of the author's descriptions." Outlook. "The author has not only produced 'a practical guide for the col. lector' but a handy book of reference for all. The volume is wonderfully cheap."

Notes and Queries.

Chats on Old Copper and Brass. By Fred W. BURGESs. With a coloured frontispiece and 86 other Illustrations. Cloth, 9s. net. "Mr. F. W. Burgess is an expert on old copper and bronze, and in his book there is little information lacking which the most ardent collector might want." The Observer. "Italian bronzes, African charms, Chinese and Japanese enamels, bells, mortars, Indian idols, dials, candlesticks, and snuff boxes, all come in for their share of attention, and the reader who has mastered Mr. Burgess's pages can face his rival in the auctionroom or the dealer in his shop with little fear of suffering by the transaction."

The Nation.

T. FISHER UNWIN LTD., 1 ADELPHI TERRACE, LONDON, W.C. 2 


\section{U N W I N'S “CHATS" S E R I E S}

Chats on Household Curios. By Fred W. Burgess. With 94 Illustrations. Cloth, 9s. net.

"Mr. Burgess gives much information about such attractive antiques as old glass and enamels, old leather work, old clocks and watches, old pipes, old seals, musical instruments, and even old samplers and children's toys. The book is, in short, an excellent and comprehensive guide for what one may call the general collector, that is, the collector who does not confine himself to one class of antique, but buys whatever he comes across in the curio line, provided that it is interesting and at moderate price."

Aberdeen Free Press.

\section{Chats on Japanese Prints. By Arthur Davison} FICKE. With a coloured frontispiece and 56 Illustrations. $\quad$ Cloth, 9s. net. Fourth Impression. "Mr. Ficke writes with the knowledge of the expert, and his history of Japanese printing from very early times and his criticism of the artists' work are wonderfully interesting."

Tatler.

"This is one of the most delightful and notable members of an attractive series. . . . A beginner who shall have mastered and mado thoroughly his own the beauty of line and the various subtlety and boldness of linear composition displayed in these sixty and odd photograph will have no mean foundation for further study." - Notes and Queries.

Chats on Old Clocks. By Arthur Hayden. With a frontispiece and 80 Illustrations. 2nd Ed. Cloth, 9s. net. "A practical handbook dealing with the examples of old clocks likely to come under the observation of the collector. Charmingly written and illustrated."

Outlook.

"One specially useful feature of the work is the prominence Mr. Hayden has given to the makers of clocks, dealing not only with those of London, but also those of the leading provincial towns. The lists he gives of the latter are highly valuable, as they are not to be found in any similar book. The volume is, as usual with this series, profusely illustrated, and may be recommended as a highly interesting and useful general guide to collectors of clocks." The Connoisseur.

Chats on Old Silver. By Arthur Hayden. With a frontispiece, 99 full-page Illustrations, and illustrated table of marks. Cloth, 9s. net. Fourth Impression. "Mr. Hayden's 'Chats on Old Silver' deals very thoroughly with a popular branch of collecting. There are a hundred full-page illustrations together with illustrated tables and charts, and the student of this book can wander round the old curiosity shops of these islands with a valuable equipment of knowledge. ... Altogether we have here a well-written summary of everything that one could wish to know about this branch of collecting."

The Sphere. "The information it gives will be of exceptional value at this time, when so many families will be forced to part with their treasuresand old silver is among the most precious possessions of the present day."

Morning Post.

T. FISHER UNWIN LTD., 1 ADELPHI TERRACE. LONDON. W.C. 2 


\section{U N W I N'S “CHATS” SERIES}

Chats on Military Curios. By Stanley C. Johnson, M.A., D.Sc. With a coloured frontispiece and 79 other Illustrations.

Cloth, 9s. net.

"Mr. Johnson in this book describes many of the articles a collector should be on the look out for, giving short but informative notes on medals, helmet and cap badges, tunic buttons, armour, weapons of all kinds, medallions, autographs, original documents relating to Army work, military pictures and prints, newspaper cuttings, obsolete uniforms, crests, stamps, postmarks, memorial brasses, money and curios made by prisoners of war, while there is also an excellent biography on the subject. The author has, indeed, presented the reader with a capital working handbook, which should prove a friendly and reliable guide when he goes collecting."

Field.

Chats on Royal Copenhagen Porcelain. By ArThur HAYDEN. With a frontispiece, 56 full-page Illustrations and illustrated tables of marks. Cloth, 9s. net.

"This very beautiful and very valuable book will be eagerly welcomed by lovers of porcelain. . . . Mr. Hayden describes with great skill and preciseness all the quality and beauty of technique in which this porcelain excels; he loves it and understands it, and the examples he has chosen as illustrations are a valuable supplement to his descriptions."

Bookman.

Chats on Old Sheffield Plate. By Arthur Hayden. With frontispiece and 58 full-page Illustrations, together with makers' marks.

Cloth, 9s. net.

Old plated ware has, by reason of its artistic excellence and its technique, deservedly won favour with collectors. The art of making plated ware, which originated at Sheffield (hence the name of "Sheffield plate "), was continued at Birmingham and London, where a considerable amount of "old Sheffield plate" was made, in the manner of its first inventors, by welding sheets of silver upon copper. The manufacture lasted roughly a hundred years. Its best period was from 1776 (American Declaration of Independence) to 1830 (Accession of William IV). The author shows reasons why this old Sheffield plate should be collected, and the volume is illustrated with many examples giving various styles and the development of the art, together with makers' marks. Candlesticks and candelabra, tea-caddies, sugarbaskets, salt-cellars, tea-pots, coffee-pots, salvers, spoons, and many other articles shown and described in the volume indicate the exquisite craftsmanship of the best period. The work stands as a companion volume to the author's "Chats on Old Silver," the standard practical guide to old English silver collecting.

T. FISHER UNWIN LTD., 1 ADELPHI TERRACE, LONDON, W C. 2 


SMITHSONIAN INSTITUTION LIBRARIES

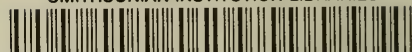

39088 00358987 b

chm NK7250.H3X

Chats on old Sheffield plate. 